\title{
RENCANA PELAKSANAAN PEMBELAJARAN BERBASIS LOCAL CONTENT GURU DAN CALON GURU SEKOLAH DASAR DI KOTA SINGARAJA
}

\author{
I Nengah Martha ${ }^{1}$, I Made Tegeh ${ }^{2}$ \\ 1Jurusan Pendidikan Bahasa dan Sastra Indonesia, Fakultas Bahasa dan Seni, \\ Universitas Pendidikan Ganesha, Singaraja, Indonesia \\ 2Jurusan Teknologi Pendidikan, Fakultas IImu Pendidikan, \\ Universitas Pendidikan Ganesha, Singaraja, Indonesia
}

\begin{abstract}
Abstrak
Penelitian ini bertujuan untuk: 1) mendapatkan informasi tentang guru-guru SD di kota Singaraja memilih atau menggunakan materi pelajaran sesuai dengan konteks, lingkungan, setting siswa, atau materi pelajaran yang berbasis local content; 2) mendapatkan informasi pada bidang studi apa saja guru-guru SD di kota Singaraja telah memilih atau menggunakan materi pelajaran sesuai dengan konteks, lingkungan, setting siswa, atau materi pelajaran yang berbasis local content; 3) mengetahui bagaimana tingkat kemampuan guru-guru SD di kota Singaraja dalam memilih, atau menggunakan materi pelajaran sesuai dengan konteks, lingkungan, setting siswa atau materi pelajaran yang berbasis local content. Penelitian ini dirancang dalam bentuk penelitian ex post facto, yang bersifat kualitatif. Data dikumpulkan dengan teknik koleksi dokumen dan dengan cara multistage stratified random sampling. Selanjutnya data dianalisis secara deskriptif dan kualitatif. Hasil penelitian ini menunjukkan: 1) RPP guru-guru SD di Kota Singaraja yang mengandung materi pelajaran berbasis local content berjumlah 302 buah $(76,46 \%)$. RPP guru-guru SD di Kota Singaraja yang tidak mengandung materi yang berbasis local content adalah 93 buah (23,54\%); 2) bidang studi Bahasa Bali secara keseluruhan menggunakan materi pelajaran yang berbasis local content. Bidang studi Bahasa Indonesia hanya menggunakan:77,57\%, Pendidikan Kewarganegaraan: 72,55\%, IImu Pengetahuan Alam: 65,79\%, Matematika: $84,09 \%$, IImu Pengetahuan Sosial: $77,27 \%$, Seni Budaya dan Keterampilan: 90\%, dan Agama Hindu: 83,33\%.; 3) Jumlah RPP yang berada pada kategri sangat cocok adalah 163 buah (53,44\%). Jumlah RPP yang berada pada kategori cukup cocok adalah 142 buah (46,56\%). Tak satu pun RPP ada pada tingkat kategori tidak cocok. Disarankan agar, para guru SD di kota Singaraja memilih dan menggunakan materi pelajaran berbasis local content untuk mendukung pembelajaran bermakna.
\end{abstract}

Kata kunci: rencana pembelajaran, local content, sekolah dasar 


\begin{abstract}
This research aims at: 1) finding out of information about teacher's elementary school in Singaraja to chose and use material in accordance with context, environment, setting of students, or material based local content; 2) finding out of information on the subject matter are the teacher's elementary school in Singaraja were chosed and used material based local content in accordance with context, environment, setting of students, or material based local content, 3) to know the degree of ability of the teacher's elementary school in Singaraja are chosing and using material in accordance with context, environment, setting of students, or material based local content. This research is designed in ex post facto research and qualitatively. The data were gathered by means collecting documents and with multistage stratified random sampling techniques. And then, the data were analyzed descriptively and qualitatively. The results of this research shows: 1) The unit lessons of teacher's elementary school in Singaraja that is contains material based local content are 302 units (76,46\%). The unit lessons of teacher's elementary school in Singaraja that have't contains material based local content are 93 units (23,54\%); 2) Balinese subject matter useful material based local content. Indonesian subject matter only use: $77,57 \%$; Education of Citizenship: 72,55\%; Sciences: 65,79\%; Matematics: 84,09\%; Social Sciences: 77,27\%; Art, Culcutural and Skills: $90 \%$; Hinduism: 83,33\%.; 3) The sum of unit lessons categorized very suitable are 163 units (53,44\%). The sum of unit lessons categorized suitable enought are 142 units $(46,56 \%)$. No one of unit lessons categorized unsuitable. Sugested that, the teacher's elementary school in Singaraja must be chose and use material based local content to supporting meaningful teaching and learning.
\end{abstract}

Keywords: unit lessons, local content, elementary school

\section{PENDAHULUAN}

Kurikulum tingkat satuan pendidikan
(KTSP) jenjang pendidikan dasar dikembangkan oleh sekolah dan komite sekolah berpedoman pada standar kompetensi lulusan dan standar isi serta panduan penyusunan kurikulum yang dibuat oleh BSNP (Depdiknas, 2005). Selanjutnya dijelaskan, beberapa prinsip yang harus diperhatikan dalam pengembangan kurikulum yang akan menjadi pedoman penyusunan rencana pelaksanaan pembelajaran bagi guru, antara lain: 1) berpusat pada potensi, perkembangan, kebutuhan, dan kepentingan peserta didik dan lingkungannya. Untuk mendukung pencapaian tujuan tersebut, pengembangan kompetensi peserta didik disesuaikan dengan potensi, perkembangan, kebutuhan, dan kepentingan peserta didik serta tuntutan lingkungan. 2) Kurikulum dikembangkan dengan memperhatikan pengembangan diri peserta didik secara terpadu, sehingga peserta didik memperoleh pengetahuan, pengalaman, dan keterampilan yang bermakna bagi kehidupannya. 3) Kurikulum dikembangkan relevan dengan kebutuhan kehidupan siswa. Untuk itu, kurikulum dikembangkan dengan melibatkan pihakpihak yang berkepentingan (stakeholders) untuk menjamin relevansi pendidikan dengan kebutuhan kehidupan nyata siswa.

Selanjutnya ditentukan bahwa, kurikulum harus dilaksanakan dengan: 1) mendayagunakan kondisi alam, sosial, dan budaya serta kekayaan lokal/daerah untuk keberhasilan pendidikan. Kondisi alam, sosial, dan budaya serta kekayaan lokal/daerah menjadi muatan kajian yang harus dimanfaatkan secara optimal. 2) Pendayagunaan kondisi alam, sosial, dan budaya serta kekayaan lokal/daerah 
tersebut haruslah berguna bagi kehidupan diri siswa.

Intinya, dalam pemilihan materi pelajaran, guru dituntut mampu memilih materi yang sesuai dan bermakna. Istilah sesuai dalam pemilihan materi pelajaran, dikaitkan dengan: 1) materi yang dipilih sesuai dengan tingkat perkembangan fisik, intelektual, emosional, dan spiritual peserta didik, 2) materi yang dipilih sesuai dengan umur, lingkungan, kebutuhan, dan jenjang pendidikan peserta didik. Istilah bermakna (meaningful) dalam pemilihan materi pelajaran dikaitkan dengan: 1) pengetahuan dan keterampilan yang dipilih bermanfaat bagi kehidupan nyata siswa, 2) materi pelajaran yang dipilih berguna dalam kehidupan siswa sehari-hari, 3) materi pelajaran yang dipilih berorientasi lingkungan yang autentik (Depdiknas, 2007).

Dalam rangka mendukung prinsip dan pelaksanaan kurikulum tingkat satuan pendidikan (KTSP) yang disebut di atas, guru diisyaratkan untuk menggunakan pendekatan CTL (contextual teaching and learning), karena pendekatan pembelajaran kontektual adalah proses pembelajaran yang holistik yang bertujuan membantu siswa untuk memahami makna materi yang dipelajari dengan cara mengaitkan materi tersebut dengan konteks kehidupan seharihari (konteks pribadi, sosial, dan budaya), sehingga siswa memiliki pengetahuan dan keterampilan yang dapat ditransfer dari satu permasalahan/konteks ke permasalahan/konteks lain.

Apabila dicermati benar mengenai pendekatan CTL ini, dapat dilihat bahwa pendekatan CTL ini amat concern terhadap pemilihan materi yang berbasis local content, baik dilihat dari segi prinsip, landasan, maupun ciri/paradigmanya, seperti dipaparkan berikut ini.

\section{Prinsip Pendekatan CTL}

a) Membuat hubungan yang bermakna (making meaningful connections) antara sekolah dan konteks kehidupan nyata, sehingga siswa merasakan bahwa belajar itu penting untuk masa depannya. b) Melakukan pekerjaan yang signifikan (doing significant work). Akivitas yang dilakukan memiliki tujuan, kepedulian, ikut serta dalam menentukan perilaku, dan menghasilkan produk yang bermanfaat bagi kehidupan nyata. c) Pembelajaran mandiri (selfregulated learning), membangun minat siswa bekerja sendiri/kelompok untuk mencapai tujuan yang bermakna dengan mengaitkan materi ajar dengan konteks kehidupan sehari-hari. d) Bekerjasama (collaborating) untuk membantu siswa bekerjasama secara efektif, sehingga siswa dapat mengkomunikasikan dan merasakan hubungan-hubungan masalah, peristiwa, dan kejadian dalam kehidupan. e) Berpikir kritis dan kreatif (critical and creative thinking) melalui pengumpulan data, analisis dan sintesis data, memahami suatu isu/fakta dan memecahkan masalah.

\section{Landasan Pendekatan CTL}

a) Knoledge based constructivism, menekankan pada pentingnya siswa membangun sendiri pengetahuannya melalui terlibat aktif dalam proses belajarmengajar. b) Socialization, belajar adalah proses sosial, karena itu faktor lingkungan, sosial, dan budaya perlu diperhatikan dalam proses belajar. c) Situated learning, belajar berlangsung dalam situasi nyata, bukan abstrak. Karena itu, konteks sosial (masyarakat, rumah, dll.) penting dikemas dalam proses belajar-mengajar. d) Problem Jurnal Pendidikan Indonesia | 67 
based learning, yakni pembelajaran yang menggunakan masalah dunia nyata, sehingga masalah yang kontekstual penting bagi siswa dalam belajar untuk memperoleh pengetahuan dan keterampilan esensial dari materi yang dipelajari. e) Authentic instruction, yakni pengajaran yang membawa siswa pada mempelajari konteks bermakna melalui pengembangan kemampuan berpikir dan memecahkan masalah penting dalam konteks kehidupan nyata. f) Inquiry based learning, pembelajaran yang memberi kesempatan untuk pembelajaran bermakna. g) Project based learning, pembelajaran dengan tugas-tugas yang memungkinkan siswa belajar mandiri dalam menyusun pengetahuannya. h) Work based learning, belajar dengan membawa pada pemecahan masalah yang nyata dalam kehidupan, sehingga tidak ada kesenjangan antara yang dipelajari dengan hal yang dihadapi. i) Service learning, belajar yang mengantarkan pada kemampuan apa yang dipelajari untuk memenuhi atau melayani kebutuhan hidup.

\section{Ciri/ Pendekatan Paradigma CTL}

a) Pembelajaran dikaitkan dengan kehidupan nyata, b) Pembelajaran dapat terjadi di berbagai tempat, konteks dan setting, c) Mengaitkan informasi dengan pengetahuan yang sudah dimiliki, d) Mengintegrasikan berbagai bidang pengetahuan yang terkait, e) Belajar untuk menemukan, menggali dan memecahkan masalah, f) Belajar dengan kesadaran diri, g) Keterampilan dikembangkan atas dasar pemahaman, sehingga maknanya dapat dirasakan.

Paparan-paparan di atas menunjukkan bahwa dari segi kurikulum (KTSP), aktivitas belajar-mengajar semestinya diarahkan pada pembelajaran yang bermakna dengan menggunakan atau memilih materi pelajaran sesuai dengan konteks, lingkungan, setting siswa atau materi pelajaran yang berbasis local content. Dari segi cara pembelajaran, untuk mencapai pembelajaran yang bermakna, sudah ditunjukkan cara/pendekatan yang dapat digunakan, yakni pembelajaran kontekstual (CTL). Menggunakan atau memilih materi pelajaran sesuai dengan konteks, lingkungan, setting siswa atau materi pelajaran yang berbasis local content, merupakan tantangan dan tidak mudah bagi guru. Hal ini perlu diungkap dalam sebuah penelitian.

Atas dasar latar belakang masalah yang diuraikan di atas, maka yang menjadi masalah pokok yang mau diungkapkan dalam penelitian ini adalah "Dalam upaya mencapai pembelajaran yang bermakna, apakah guru-guru SD di kota Singaraja telah memilih atau menggunakan materi pelajaran sesuai dengan konteks, lingkungan, setting siswa atau materi pelajaran yang berbasis local content?"

Sejalan dengan masalah pokok tersebut, lebih rinci masalah yang akan diungkap dalam penelitian ini adalah sebagai berikut.

1. Apakah guru-guru SD di kota Singaraja telah memilih atau menggunakan materi pelajaran sesuai dengan konteks, lingkungan, setting siswa atau materi pelajaran yang berbasis local content?

2. Pada bidang studi/mata pelajaran apa sajakah guru-guru SD di kota Singaraja telah memilih atau menggunakan materi pelajaran sesuai dengan konteks, lingkungan, setting siswa atau materi pelajaran yang berbasis local content?

3. Bagaimanakah tingkat kemampuan guru-guru SD di kota Singaraja Jurnal Pendidikan Indonesia | 68 
dalam memilih atau menggunakan materi pelajaran sesuai dengan konteks, lingkungan, setting siswa atau materi pelajaran yang berbasis local content?

Sejalan dengan masalah yang ingin diungkap, tujuan pokok penelitian ini adalah "untuk memperoleh informasi tentang apakah guru-guru SD di kota Singaraja telah memilih atau menggunakan materi pelajaran sesuai dengan konteks, lingkungan, setting siswa atau materi pelajaran yang berbasis local content dalam upaya mencapai pembelajaran yang bermakna". ini adalah:

Secara lebih rinci, tujuan penelitian

1. untuk mendapatkan informasi apakah guru-guru SD di kota Singaraja telah memilih atau menggunakan materi pelajaran sesuai dengan konteks, lingkungan, setting siswa atau materi pelajaran yang berbasis local content;

2. untuk mendapatkan informasi pada bidang studi/mata pelajaran apa saja guru-guru SD di kota Singaraja telah memilih atau menggunakan materi pelajaran sesuai dengan konteks, lingkungan, setting siswa atau materi pelajaran yang berbasis local content;

3. untuk mengetahui bagaimana tingkat kemampuan guru-guru SD di kota Singaraja dalam memilih atau menggunakan materi pelajaran sesuai dengan konteks, lingkungan, setting siswa atau materi pelajaran yang berbasis local content.

\section{METODE}

Jika dilihat dari sumber data, penelitian ini termasuk penelitian expost facto, karena data yang dikumpulkan telah ada dan terjadi apa adanya. Jika dilihat dari jenis datanya, penelitian ini termasuk penelitian kualitatif, karena data yang dikumpulkan dalam bentuk pernyataan verbal. Jika dilihat dari segi penyajian data, penelitian ini termasuk penelitian deskriptif, karena data digambarkan secara deskriptif dan naratif. Jika dilihat dari segi tujuan, penelitian ini termasuk penelitian survey, karena ingin memetakan gejala atau variabel dalam suatu wilayah dengan cara reduksi (dalam mengambil sampel), dan generalisasi (dalam membuat kesimpulan).

Seperti dikatakan oleh Fraenkel dan Wallen (1993), "the mayor purpose of surveys is to describe the characteristics of population. In essence, what researchers want to find out is how the members of a population distribute themselves on one or more variables" (tujuan utama survei adalah untuk menggambarkan ciri/sifat (kondisi variabel) dari populasi. Jadi, apa yang peneliti ingin dapatkan tidak lain adalah bagaimana anggota populasi mendistribusikan dirinya dalam satu atau beberapa variabel). Sesuai dengan pernyataan itu penelitian ini ingin mendapatkan gambaran tentang kemampuan para guru SD memilih materi pelajaran yang berbasis local content.

Survei dapat dilakukan pada seluruh anggota populasi, tetapi dapat juga dilakukan pada beberapa anggota populasi (sampel). Jadi survei bisa bersifat the whole or the part. Dalam hal ini peneliti menggunakan pendekatan the part, yakni akan digunakan pendekatan reduksi dan generalisasi, dengan menggunakan teknik sampling.

Objek penelitian ini adalah LOCAL CONTENT yang ada dalam rencana pelaksanaan pembelajaran (RPP), yang mencakupi:

1. Apakah guru-guru SD di kota Singaraja telah memilih atau menggunakan materi pelajaran yang berbasis local content.

Jurnal Pendidikan Indonesia | 69 
2. Pada bidang studi/mata pelajaran apa saja guru-guru SD di kota Singaraja telah memilih atau menggunakan materi pelajaran yang berbasis local content.

3. Tingkat kemampuan guru-guru SD di kota Singaraja dalam memilih atau menggunakan materi pelajaran yang berbasis local content.

Subjek penelitian ini adalah rencana pelaksanaan pembelajaran (RPP) yang dibuat oleh guru dan calon guru SD di kota Singaraja. Rencana pelaksanaan pembelajaran itu dapat berupa rencana pelaksanaan pembelajaran berbagai bidang studi yang diajarkan di SD, dan semua jenjang kelas di SD. Jadi populasi penelitian ini adalah rencana pelaksanaan pembelajaran yang dibuat oleh guru pada semua bidang studi yang diajarkan dan pada semua jenjang kelas di SD.

Karena populasi cukup banyak, maka penelitian ini menggunakan pendekatan reduksi dan generalisasi (perampatan). Untuk itu digunakan teknik sampling. Dalam hal ini, sampel diambil dengan menggunakan teknik: stratified random sampling. Teknik stratified diterapkan berhubung ada guru swasta dan guru negeri; ada guru kelas 1, 2. 3, 4, 5, dan 6. Teknik random digunakan karena semua guru dari berbagai status sekolah, berbagai bidang studi, dan berbagai kelas diberi kesempatan menjadi sampel dengan cara diacak. Jumlah sampel yang diambil didasarkan pada pertimbangan apakah jumlah sampel itu sudah dapat mewakili populasi atau dengan kata lain, apakah sampel itu sudah dianggap representatif.

Data dikumpulkan dengan menghimpun rencana pelaksanaan pembelajaran yang dibuat oleh para guru SD yang mengajar berbagai bidang studi, pada sekolah negeri maupun swasta, serta yang mengajar di kelas 1, 2, 3, 4, 5, dan 6 . Dengan demikian, data dikumpulkan dengan cara/metode koleksi dokumen.

Untuk menjawab masalah pertama, data dianalisis dengan teknik kategorisasi, yang dilanjutkan dengan analisis distribusi frekuensi. Untuk menjawab masalah kedua, data dianalisis dengan teknik pemilahan, yang dilanjutkan dengan analisis tendensi sentral dan penghitungan persentase. Untuk menjawab masalah ketiga, data dianalisis dengan teknik kecocokan bergradasi dengan memakai deskriptor, sehingga menghasilkan indeks yang dapat digunakan untuk membuat skala penilaian untuk menilai jenjang kemampuan guru dalam memilih dan menggunakan materi pelajaran yang berbasis local content. Terakhir, semua hasil analisis data tersebut disajikan secara deskriptif dan naratif. Analisis ini dilakukan oleh dua orang untuk menjaga kesahihan hasil penelitian.

\section{HASIL}

\section{Pemilihan atau Penggunaan Materi Pelajaran yang Berbasis Local Content oleh Guru SD di Kota Singaraja}

Berdasarkan hasil analisis data diperoleh hasil penelitian sebagai berikut. RPP guru-guru SD di Kota Singaraja yang mengandung materi pelajaran yang berbasis local content berjumlah 302 buah. RPP guru-guru SD di Kota Singaraja yang tidak mengandung materi yang berbasis local content adalah 93 buah. Persentase RPP yang mengandung materi pelajaran yang berbasis local content $=(302: 395) \times 100 \%$ $=76,46 \%$. Persentase RPP yang tidak mengandung materi pelajaran yang berbasis local content $=(93: 395) \times 100 \%=23,54 \%$.

Jurnal Pendidikan Indonesia | 70 
2. Bidang Studi yang Menggunakan Materi Pelajaran Berbasis Local Content

Tabel 1 menyajikan data tentang bidang studi yang menggunakan dan tidak menggunakan materi pelajaran yang berbasis local content.

Tabel 1: Bidang Studi yang Menggunakan dan Tidak Menggunakan Local Content

\begin{tabular}{|c|c|c|c|c|c|c|}
\hline No. & $\begin{array}{l}\text { Bidang } \\
\text { Studi }\end{array}$ & $\begin{array}{c}\text { Jumlah } \\
\text { RPP }\end{array}$ & $\begin{array}{c}\text { Jumlah } \\
\text { yang } \\
\text { Menggu- } \\
\text { nakan } \\
\text { Local } \\
\text { Content }\end{array}$ & $\begin{array}{l}\text { Persen- } \\
\text { tase } \\
(\%)\end{array}$ & $\begin{array}{c}\text { Jumlah } \\
\text { yang Tidak } \\
\text { Menggu- } \\
\text { nakan } \\
\text { Local } \\
\text { Content }\end{array}$ & $\begin{array}{c}\text { Persentase } \\
(\%)\end{array}$ \\
\hline 1 & Bahasa Indonesia & 107 & 83 & 77,57 & 24 & 22,43 \\
\hline 2 & PKn & 51 & 37 & 72,55 & 14 & 27,45 \\
\hline 3 & IPA & 76 & 50 & 65,79 & 26 & 34,21 \\
\hline 4 & Matematika & 88 & 74 & 84,09 & 14 & 15,91 \\
\hline 5 & IPS & 44 & 34 & 77,27 & 10 & 22,73 \\
\hline 6 & Bahasa Bali & 13 & 13 & 100,00 & 0 & 0,00 \\
\hline 7 & SBK & 10 & 9 & 90,00 & 1 & 10,00 \\
\hline 8 & Agama Hindu & 6 & 5 & 83,33 & 1 & 16,67 \\
\hline & Jumlah & 395 & 305 & 77,21 & 90 & 22,79 \\
\hline
\end{tabular}

Keterangan:

$\mathrm{SBK}=$ Seni Budaya dan Keterampilan

Berdasarkan data pada Tabel 4.2 dapat diketahui bahwa dari seluruh RPP yang dianalisis, terdapat 305 RPP yang telah menggunakan materi pelajaran yang berbasis local content dan 90 RPP yang tidak menggunakan materi pelajaran yang berbasis local content. Persentase secara keseluruhan guru-guru SD di kota Singaraja yang telah memilih atau menggunakan materi pelajaran yang berbasis local content adalah $77,21 \%$, sedangkan persentase guru-guru SD yang tidak menggunakan materi pelajaran yang berbasis local content adalah $22,79 \%$.

Dari delapan bidang studi yang dianalisis, bidang studi yang secara keseluruhan menggunakan materi pelajaran yang berbasis local content adalah Bahasa Bali. Ketujuh bidang studi lainnya, memiliki variasi dalam hal persentase penggunaan materi pelajaran berbasis local content. Pada bidang studi Bahasa Indonesia, perbandingan persentase antara guru yang telah memilih atau menggunakan materi pelajaran berbasis local content dan guru yang tidak memilih atau menggunakan materi pelajaran berbasis local content adalah 77,57\%: 22,43\%. Pada bidang studi Pendidikan Kewarganegaraan: 72,55\%: 27,45\%, IImu Pengetahuan Alam: 65,79\%: 34,21\%, Matematika: 84,09\%: 15,91\%, IImu Pengetahuan Sosial: 77,27\%: 22,73\%, Seni Budaya dan Keterampilan: 90\%: 10\%, dan Agama Hindu: 83,33\%: 16,67\%. 
3. Tingkat Kemampuan Guru SD di Kota Singaraja dalam Memilih atau Menggunakan Materi Pelajaran yang Berbasis Local Content

Sesuai dengan data dan hasil penelitian yang telah dipaparkan di atas, maka diketahui bahwa, dari 395 RPP yang dianalisis, RPP yang telah menggunakan materi pelajaran yang berbasis local content adalah 305 buah. Dalam menjawab rumusan masalah penelitian ketiga ini, analisis dilakukan terhadap 305 RPP yang telah menggunakan materi pelajaran yang berbasis local content.

Tingkat kemampuan guru SD di Kota Singaraja dalam memilih atau menggunakan materi pelajaran yang berbasis local content dapat dilihat dari tingkat kecocokan penggunaan materi pelajaran yang berbasis local content. Tingkat kecocokan ini ditentukan dengan bantuan deskriptor, yang menghasilkan indeks untuk menyusun skala penilaian. Tingkat kecocokan dikategorikan menjadi tiga, yakni sangat cocok, cukup cocok, dan tidak cocok. Sangat cocok, jika materi yang digunakan/dipilih sangat dekat dengan lingkungan siswa ( atau dengan indeks 5). Cukup cocok, jika materi yang digunakan/dipilih cukup dekat dengan lingkungan siswa (atau dengan indeks 3) Tidak cocok, jika materi yang digunakan/dipilih sangat jauh dengan lingkungan siswa (tingkat kecocokan (atau dengan indeks 1). Misalnya: Pembelajaran proses membuat tempe/tahu sangat dekat bagi siswa SD Kampung Baru Singaraja. Pembelajaran proses cara menyetek dan menanam pohon kopi cukup dekat bagi siswa SD Kampung Baru Singaraja. Pembelajaran proses cara membuat sepatu di Cibaduyut sangat jauh bagi siswa SD Kampung Baru Singaraja. Jadi, semakin tinggi tingkat kecocokan, maka tingkat kemampuan guru-guru SD di kota Singaraja dalam memilih atau menggunakan materi pelajaran yang berbasis local content akan semakin tinggi pula. Tabel 2 menyajikan data tentang tingkat kecocokan penggunaan materi pelajaran yang berbasis local content pada RPP yang telah dianalisis.

Tabel 2: Tingkat Kecocokan Penggunaan Materi Pelajaran yang Berbasis Local Content

\begin{tabular}{|c|l|c|c|c|c|}
\hline \multirow{2}{*}{ No. } & \multirow{2}{*}{ Bidang Studi } & \multirow{2}{*}{$\begin{array}{c}\text { Jumlah } \\
\text { RPP }\end{array}$} & & \multicolumn{3}{|c|}{ Tingkat Kecocokan } \\
\cline { 4 - 6 } & & Sangat Cocok & Cukup Cocok & $\begin{array}{c}\text { Tidak } \\
\text { Cocok }\end{array}$ \\
\hline 1 & Bahasa Indonesia & 83 & 42 & 41 & 0 \\
\hline 2 & PKN & 37 & 18 & 19 & 0 \\
\hline 3 & IPA & 50 & 30 & 20 & 0 \\
\hline 4 & Matematika & 74 & 38 & 36 & 0 \\
\hline 5 & IPS & 34 & 20 & 14 & 0 \\
\hline 6 & Bahasa Bali & 13 & 7 & 6 & 0 \\
\hline
\end{tabular}




\begin{tabular}{|c|l|c|c|c|c|}
\hline 7 & SBK & 9 & 4 & 5 & 0 \\
\hline 8 & Agama Hindu & 5 & 4 & 1 & 0 \\
\hline$\quad$ Jumlah & 305 & 163 & 142 & 0 \\
\hline \multicolumn{2}{r|}{ Persentase } & $100 \%$ & $53,44 \%$ & $46,56 \%$ & $0 \%$ \\
\hline
\end{tabular}

Data pada tabel 2 dapat diketahui bahwa, tingkat kecocokan penggunaan materi pelajaran yang berbasis local content berada pada tingkat sangat cocok dan cukup cocok. RPP yang berada pada tingkat kecocokan sangat cocok adalah 163 buah atau setara dengan $53,44 \%$. RPP yang berada pada tingkat kecocokan cukup cocok adalah 142 buah atau setara dengan $46,56 \%$. Tak satu pun RPP yang berada pada tingkat kecocokan dalam kategori tidak cocok.

\section{PEMBAHASAN}

Pada bagian ini dipaparkan pembahasan terhadap hasil-hasil penelitian sebagaimana diuraikan sebelumnya. Pembahasan dipaparkan secara sistematis berdasarkan urutan hasil penelitian. Pembahasan mencakup tiga hal pokok, yakni: (1) pemilihan atau penggunaan materi pelajaran yang berbasis local content, (2) bidang studi yang telah menggunakan materi pelajaran berbasis local content, dan (3) tingkat kemampuan guru SD dalam memilih atau menggunakan materi pelajaran yang berbasis local content.

Berdasarkan hasil analisis data diketahui bahwa RPP guru-guru SD di kota Singaraja yang mengandung materi pelajaran berbasis local content berjumlah 302 buah (76,46\%). RPP guru-guru SD di kota Singaraja yang tidak mengandung materi yang berbasis local content adalah 93 buah (23,54\%). Dengan demikian, guruguru SD di kota Singaraja ada yang telah memilih atau menggunakan materi pelajaran berbasis local content dan ada pula guru yang tidak memilih atau menggunakan materi pelajaran berbasis local content. Data hasil penelitian menunjukkan bahwa lebih banyak guru yang telah memilih atau menggunakan materi pelajaran berbasis local content dibandingkan dengan guru yang tidak memilih atau menggunakan materi pelajaran berasis local content. Hal tersebut mengindikasikan adanya usaha keras para guru SD di kota Singaraja untuk menggunakan materi pelajaran yang berbasis local content. Ini berarti bahwa, guru telah perupaya membawa pembelajarannya ke pembelajaran yang kontekstual, agar membelajaran tersebut bermakna (meaningful).

Usaha keras guru SD di kota Singaraja untuk memilih atau menggunakan materi pelajaran yang berbasis local content telah terbukti. Hal ini tampak dari cukup banyaknya RPP yang berisi materi pelajaran berbasis local content. Tiga perempat lebih RPP guru-guru SD di kota Singaraja telah menggunakan materi pembelajaran berbasis local content.

Beberapa hal yang menyebabkan para guru telah memilih atau menggunakan materi pembelajaran berbasis local content adalah sebagai berikut.

Pertama, kegiatan Kelompok Kerja Guru (KKG) yang telah dilaksanakan para guru SD memberikan inspirasi untuk saling bertukar pikiran dalam memecahkan permasalahan yang dihadapi dalam 
pembelajaran. Melalui KKG para guru dapat saling bertukar pikiran tentang materi pelajaran yang mereka berikan di kelas masing-masing.

Kedua, pendidikan dan pelatihan serta berbagai kegiatan ilmiah yang diikuti oleh para guru membuka wawawasan para guru tentang pendekatan pembelajaran kontekstual. Guru-guru SD telah banyak yang mengikuti berbagai kegiatan ilmiah, seperti: lokakarya, seminar, pendidikan dan latihan (diklat), dan lain sebagainya. Keikutsertaan guru dalam berbagai kegiatan ilmiah memberi dampak positif bagi guru untuk meningkatkan profesionalisme guru dalam melaksanakan tugas-tugas keguruannya.

Ketiga, peran supervisi kepala sekolah dan pengawas SD memberikan sumbangan untuk peningkatan kreativitas para guru SD dalam mengembangkan dan meningkatkan perencanaan dan pelaksanaan pembelajaran di kelas masingmasing. Oleh karena itu, supervisi kepala sekolah dan pengawas pendidikan kepada para guru perlu dilakukan secara berkesinambungan.

Keempat, ketersediaan berbagai sumber belajar yang mudah diakses oleh para guru SD sangat mendukung pengembangan pengetahuan dan wawasan para guru untuk terus- meningkatkan kualitas materi pelajaran. Sumber-sumber belajar seperti internet, buku elektronik, berbagai buku pelajaran yang diterbitkan oleh penerbit yang berbeda-beda, berbagai lembar kerja siswa, koran, majalah, dan lain sebagainya memberikan inspirasi bagi para guru SD untuk mengembangkan materi pembelajaran sesuai dengan kebutuhan para siswa mereka.

Selain faktor-faktor pendukung sebagaimana dipaparkan di atas, terdapat beberapa faktor penghabat yang menyebabkan para guru SD tidak memilih atau menggunakan materi pelajaran yang berbasis local content dalam RPP yang mereka rancang. Faktor penghambat tersebut kemungkinan yang menjadi alasan para guru tidak memilih atau menggunakan materi pelajaran yang berbasis local content. Kemungkinan alasan ini diperoleh berdasarkan hasil telaah mendalam terhadap RPP yang dibuat oleh para guru SD. Kemungkinan-kemungkinan alasan tersebut adalah sebagai berikut.

Pertama, berdasarkan pengamatan ternyata gambar-gambar yang digunakan dalam RPP yang dibuat oleh para guru mengambil dari buku-buku sumber yang diterbitkan di luar propinsi Bali. Hal ini menyebabkan gambar-gambar yang digunakan tidak sesuai dengan lingkungan tempat para siswa beraktivitas.

Kedua, selain gambar, para guru SD juga kurang kreatif dalam mengembangkan materi pelajaran. Mereka cenderung mengambil materi yang ada pada buku pelajaran yang mereka miliki, tanpa menyesuaikan dengan situasi dan kondisi lingkungan dan keadaan para siswa yang diasuhnya. Materi-materi pada buku yang dicetak dan diterbitkan oleh penerbit di Jawa, tentu tidak semuanya sesuai dengan keadaan di Bali, sehingga perlu diadaptasi terlebih dahulu, bukan diambil begitu saja.

Ketiga, nama-nama tokoh yang digunakan oleh para guru dalam materi pelajaran tidak sesuai dengan nama-nama para siswa, sehingga nama-nama tokoh tersebut terasa asing di telinga para siswa. Hal ini disebabkan para guru dalam mengambil nama-nama tokoh yang digunakan dalam materi pelajaran hanya mengambil atau mencontoh dari sumber yang mereka gunakan. Misalnya, mengambil Jurnal Pendidikan Indonesia | 74 
nama tokoh dari buku paket, internet, majalah, dan lain sebagainya. Seharusnya para guru mengadaptasi nama tokoh yang digunakan dalam materi pelajaran, sehingga nama-nama tokoh tidak asing bagi para siswa.

Keempat, beberapa contoh yang ditulis para guru pada RPP sangat umum dan abstrak, sehingga contoh-contoh tersebut tidak kontekstual. Bahkan terdapat beberapa RPP yang uraian materinya tidak jelas, karena hanya mencantumkan materi secara singkat. Demikian pula tema-tema yang diangkat dalam materi pelajaran tidak relevan dengan keadaan real yang dihadapi para siswa dalam kehidupan sehari-hari mereka.

Dari delapan bidang studi yang dianalisis, hanya bidang studi Bahasa Bali yang secara keseluruhan menggunakan materi pelajaran yang berbasis local content. Bahasa Bali merupakan bidang studi muatan lokal (mulok) yang memberikan kekhasan bagi sekolah-sekolah yang ada di Bali. Pembelajaran bahasa Bali mencakup kegiatan membaca, menulis, menyimak, dan berbicara bahasa Bali. Dalam keempat kegiatan tersebut para guru SD telah memilih alur cerita, nama-nama tokoh, latar materi, dan contoh-contoh yang mencerminkan kehidupan sehari-hari masyarakat Bali.

Ketujuh, bidang studi lainnya, memiliki variasi dalam hal persentase penggunaan materi pelajaran berbasis local content. Pada bidang studi Bahasa Indonesia, persentase guru yang telah memilih atau menggunakan materi pelajaran berbasis local content adalah 77,57\%. Pada bidang studi Pendidikan Kewarganegaraan: 72,55\%, IImu Pengetahuan Alam: 65,79\%, Matematika: 84,09\%, IImu Pengetahuan Sosial: $77,27 \%$, Seni Budaya dan
Keterampilan: 90\%, dan Agama Hindu: $83,33 \%$.

$\begin{array}{ll}\text { Pada ketujuh bidang studi, yaitu } \\ \text { Bahasa } & \text { Indonesia, } \\ \text { Pendidikan }\end{array}$
Kewarganegaraan, IImu Pengetahuan Alam, Matematika, IImu Pengetahuan Sosial, Seni Budaya dan Keterampilan, serta Agama Hindu terlihat bahwa persentase guru yang telah memilih atau menggunakan materi pelajaran berbasis local content lebih besar dibandingkan yang tidak memilih atau menggunakan materi pelajaran berbasis local content. Faktor pendukung dan faktor penghambat bagi guru dalam memilih atau menggunakan materi pelajaran yang berbasis local content adalah sebagaimana yang telah diuraikan sebelumnya.

Usaha yang penting untuk dilakukan dalam upaya penggunaan materi pelajaran berbasis local content pada semua mata pelajaran adalah sebagai berikut.

Pertama, peningkatan dan pemantapan terhadap berbagai faktor pendukung pemilihan atau penggunaan materi pelajaran yang berbasis local content. Hal ini dapat dilakukan dengan pengawasan yang melekat (waskat) oleh kepala sekolah dan pengawas pendidikan terhadap kinerja guru dalam membuat rencana pelaksanaan pembelajaran. Hal lain yang dapat dilakukan adalah memberikan penguatan dan motivasi kepada para guru untuk terus mengembangkan materi pelajaran berbasis local content.

Kedua, mengeliminasi segala faktor penghambat yang menyebabkan para guru tidak memilih atau menggunakan materi pelajaran berbasis local content. Hal yang dapat dilakukan adalah menggugah kesadaran para guru SD tentang arti penting penggunaan materi pelajaran berbasis local content. Kegiatan lain yang dapat dilakukan adalah meningkatkan keikutsertaan para Jurnal Pendidikan Indonesia | 75 
guru dalam berbagai kegiatan ilmiah dan kegiatan kelompok seprofesi untuk meningkatkan profesionalitas para guru.

Sebagaimana

diuraikan

sebelumnya, terungkap bahwa tingkat kecocokan penggunaan materi pelajaran yang berbasis local content berada pada dua kategori, yaitu: tingkat sangat cocok dan cukup cocok. Tak satu pun RPP yang berada pada tingkat kecocokan dalam kategori tidak cocok. Jumlah RPP yang berada pada tingkat kecocokan sangat cocok adalah 163 buah atau setara dengan $53,44 \%$. Jumlah RPP yang berada pada tingkat kecocokan cukup cocok adalah 142 buah atau setara dengan 46,56\%. Perbandingan antara persentase RPP yang berada pada kategori sangat cocok dan cukup cocok adalah 53,44\%: 46,56\%.

Perbandingan persentase tersebut menunjukkan bahwa, secara umum RPP rancangan para guru SD di Kota Singaraja lebih banyak berada pada kategori sangat cocok. Hal yang sangat membanggakan adalah tidak ada satu pun RPP yang berada pada kategori tidak cocok. Hal ini berarti para guru SD di Kota Singaraja, memiliki tingkat kemampuan yang tinggi dan cukup tinggi dalam memilih atau menggunakan materi pelajaran berbasis local content. Ini berarti juga bahwa guru berupaya melaksanakan pembelajaran yang berbasis pendekatan kontekstual untuk menjadikan pembelajarannya lebih bermakna (meaningful).

Terdapat beberapa faktor yang mempengaruhi tingkat kemampuan guru dalam memilih atau menggunakan materi pelajaran yang berbasis local content. Faktor-faktor tersebut dikelompokkan menjadi dua, yaitu faktor internal dan faktor eksternal. Faktor internal adalah faktor yang berasal dari dalam diri guru itu sendiri, misalnya minat dan bakat, kemampuan intelegensi, kreativitas, motivasi, komitmen, dan lain sebagainya. Faktor eksternal adalah faktor yang berasal dari luar diri guru, misalnya: situasi tempat kerja, lingkungan sosial, suasana akademik, kepemimpinan kepala sekolah, dan lain sebagainya.

Kemampuan guru dalam memilih atau menggunakan materi pelajaran yang berbasis local content perlu dipertahankan dan bila memungkinkan terus ditingkatkan. Usaha-usaha yang dapat dilakukan antara lain: (1) pelibatan guru dalam berbagai kegiatan ilmiah seperti seminar, lokakarya, dan pelatihan tentang pengembangan materi pelajaran berbasis local content, (2) penyediaan berbagai sumber atau referensi tentang pengembangan materi pelajaran berbasis local content, (3) pemberian penguatan kepada para guru yang telah memilih atau menggunakan materi pelajaran berbasis local content, dan (4) pemberian motivasi dan bimbingan serta supervisi klinis kepada para guru yang tidak memilih atau menggunakan materi pelajaran berbasis local content.

\section{SIMPULAN}

Berdasarkan hasil penelitian dan pembahasan, maka dapat ditarik simpulan sebagai berikut.

1. Guru-guru SD di kota Singaraja ada yang telah memilih atau menggunakan materi pelajaran berbasis local content dan ada pula guru yang tidak memilih atau menggunakan materi pelajaran berbasis local content. Berdasarkan hasil analisis data diketahui bahwa RPP guru-guru SD di Kota Singaraja yang mengandung materi pelajaran berbasis local content berjumlah 302 buah (76,46\%). RPP guru-guru SD di Kota Singaraja yang tidak mengandung 
materi yang berbasis local content adalah 93 buah $(23,54 \%)$.

2. Dari delapan bidang studi yang dianalisis, hanya bidang studi Bahasa Bali yang secara keseluruhan menggunakan materi pelajaran yang berbasis local content. Pada bidang studi Bahasa Indonesia, persentase guru yang telah memilih atau menggunakan materi pelajaran berbasis local content adalah 77,57\%. Pada bidang studi Pendidikan Kewarganegaraan: 72,55\%, IImu Pengetahuan Alam: 65,79\%, Matematika: 84,09\%, IImu Pengetahuan Sosial: $77,27 \%$, Seni Budaya dan Keterampilan: $90 \%$, dan Agama Hindu: 83,33\%.

3. Para guru SD di Kota Singaraja memiliki tingkat kemampuan yang tinggi dan cukup tinggi dalam memilih atau menggunakan materi pelajaran berbasis local content. Jumlah RPP yang berada pada tingkat kecocokan sangat cocok adalah 163 buah atau setara dengan $53,44 \%$. Jumlah RPP yang berada pada tingkat kecocokan cukup cocok adalah 142 buah atau setara dengan $46,56 \%$. Tak satu pun RPP yang berada pada tingkat kecocokan dalam kategori tidak cocok.

\section{SARAN}

Berdasarkan hasil-hasil yang diperoleh dalam penelitian ini, maka dalam uraian berikut ini disampaikan beberapa saran.

1. Para guru SD di kota Singaraja yang telah memilih atau menggunakan materi pelajaran berbasis local content diharapkan untuk terus mengembangkan diri dan meningkatkan profesinalisme guru, serta mengimbaskan pengetahuan dan keterampilan yang dimiliki kepada guru lain. Para guru SD di kota Singaraja yang tidak memilih atau menggunakan materi pelajaran berbasis local content disarankan untuk mencoba memilih atau menggunakan materi pelajaran berbasis local content agar tercipta pembelajaran yang kontekstual dan bermakna.

2. Para guru SD yang mengajar bidang studi Bahasa Indonesia, Pendidikan Kewarganegaraan, Ilmu Pengetahuan Alam, Matematika, IImu Pengetahuan Sosial, Seni Budaya dan Keterampilan, dan Agama Hindu yang tidak memilih atau menggunakan materi pelajaran berbasis local content disarankan untuk segera memilh materi pelajaran berbasis lokal content.

3. Tingkat kemampan guru SD di kota Singaraja dalam memilih atau menggunakan materi pelajaran yang berbasis local content perlu terus ditingkatkan melalui berbagai kegiatan seperti seminar, pelatihan, lokakarya, diskusi kelompok kerja guru, dan lain sebagainya.

\section{DAFTAR RUJUKAN}

Atkinson, D. 1999. "TESOL and Culture" TESOL QUARTERLY. 33 (4), 625 649.

BSNP. 2006. Panduan Penyusunan Kurikulum Tingkat Satuan Pendidikan. Jakarta: Depdiknas.

Carson. 1999. "Cross-cultural Differences in Learning Style of Elementary Age Students from Ethnic Background" Journal of Multicultural and Development, 78 (2), 29 - 35.

Chambers, F. 1997. "Seeking Concensus in Coursebook Evaluation" ELT Journal. 51 (1), $39-45$.

Depdiknas. 2003. Kurikulum 2004: Standar Kompetensi Mata Pelajaran Bahasa Indonesia. Jakarta: Pusat Kurikulum Balitbang-Depdiknas.

Depdiknas. 2007. Model Kurikulum Bahasa Indonesia Masa Depan. Tersedia: www. 
puskur.net/download/naskahakademi k/naskahakademikbindonesia/naskah akade

mikbindonesia.doc+praktek+penilaian +autentik [1 Januari 2007].

Forsyth, I; Jolliffe, A; and Stevens, D. 1995. Planning $A$ Course: Practical Stratigies for Teachers, Lectures, and Trainers. London: Kogan Page Limited.

Kubota, R. 1999. "Javanese Culture Constructed by Discourses: Implications for Applied Linguistics Research and ELT" TESOL QUARTERLY. 33 (1), 9-31.

Prihantoro, F.X.T.H. 2007. Jangan Sampai KTSP Menjadi Kurikulum Tidak Siap Pakai. Majalah Educare Nomor 4/IV/Juli 2007, hal $35-36$ ).

Puskur-Depdiknas. 2003. Pendekatan Kontekstual (Contextual Teaching and Learning) [Online]. Tersedia:http://www.geocities.com/pa kguruonline/pend konteks ba b2a.html [Diakses, 10 Januari 2007].

Puskur-Depdiknas. 2003. Kurikulum 2004: Pedoman Khusus Pengembangan Silabus dan Penilaian Mata Pelajaran Bahasa dan Sastra Indonesia. Jakarta: Depdiknas.

Ramly, M. 2007. Peningkatan Mutu Sumberdaya Manusia melalui Bahasa, Sastra dan Seni (Makalah) Pertemuan Forum Fakultas Pendidikan Bahasa, Sastra dan Seni Se-Indonesia IX. Makassar, 13 Juli 2007.

Sarkim, T. 2007. KTSP Lahir Prematur, Perlu Penegakan Otonomi Sekolah. Majalah Educare Nomor 4/IV/Juli 2007, hal $7-9$ ).

Sudaryono, S. 2007. KTSP Berpeluang Membangun Pribadi-pribadi Cerdas, Meski Dibangun di atas Pondasi yang Keropos. Majalah Educare Nomor 4/IV/Juli 2007, hal 4-6).

Verma, S. 1995. Curriculum and Standards Framework. Carlton-Victoria: Lithocraft Graphics. 


\title{
PENGEMBANGAN MODEL PEMBELAJARAN SASTRA BERBASIS KARAKTER DAN LOKALITAS DALAM MATA KULIAH DRAMA, JURUSAN PENDIDIKAN BAHASA INGGRIS UNIVERSITAS PENDIDIKAN GANESHA SINGARAJA
}

\author{
Kadek Sonia Piscayanti \\ Jurusan Pendidikan Bahasa Inggris, Universitas Pendidikan Ganesha, \\ Singaraja, Indonesia \\ e-mail: sonia_pisca@yahoo.com
}

\begin{abstract}
Abstrak
Pembelajaran drama di Jurusan Pendidikan Bahasa Inggris Universitas Pendidikan Bahasa Inggris selama ini menggunakan naskah-naskah karya penulis luar negeri. Hal ini menjadi beban bagi mahasiswa karena adanya kesenjangan antara latar budaya di dalam naskah dengan latar budaya mahasiswa. Kesenjangan budaya ini menyebabkan mahasiswa kesulitan memahami teks. Persoalan budaya adalah hal yang sangat penting dalam pembelajaran bahasa. Pembelajaran bahasa akan berhasil jika pembelajaran bersifat kontekstual, berkarakter dan bermakna. Penelitian ini bertujuan mengembangkan model pembelajaran drama berbasis karakter dan lokalitas. Metode yang digunakan adalah model pengembangan Dick, Carey and Carey (2001). Pengembangan ini melalui sembilan tahapan. Hasilnya adalah produk model pembelajaran drama berbasis karakter dan lokalitas. Bahan ajar yang dihasilkan adalah naskah drama berbasis karakter dan lokalitas. Model dan naskah ini kemudian diimplementasikan dan diujikan pada mahasiswa. Hasilnya adalah terdapat perbedaan signifikan antara prestasi mahasiswa yang diajar dengan model pembelajaran drama berbasis karakter dan lokalitas dengan prestasi mahasiswa yang tidak mendapat perlakuan.
\end{abstract}

Kata kunci: drama, model, pembelajaran, karakter, lokalitas

\begin{abstract}
Drama learning process in English Education Department has been using the literature written by western authors. This has become the burden for students since there is a gap between the culture of the text and the student's culture. This becomes the biggest challenge for the students to understand the text. The culture background is a very important issue in learning a language. Language learning can be successful if there is a contextual, character-based and meaningful learning. This research is aimed at developing the character and local-based drama learning model. The method used was Dick, Carey and Carey (2001) development method. There are nine steps of the model development. The final products are the character and local-based drama learning model and character and local-based script. The model and the script were then implemented and tested. The result : "there was a significant difference between the students taught by character and local-based drama learning model and the students who were not."
\end{abstract}

Keywords: drama, model, learning, character and locality. 


\section{PENDAHULUAN}

Sastra adalah mata kuliah yang sangat penting dalam pembelajaran bahasa. Sastra memperkaya, memperdalam, memperluas daya pikir, daya analisis kritis, dan imajinasi manusia. Bahasa dalam sastra tak hanya berfungsi sebagai alat untuk mengungkapkan ide, namun juga menyampaikan pesan. Pesan yang ingin disampaikan dalam sastra adalah sebuah nilai. Nilai yang dimaksud bisa berupa nilai moral, pembentukan karakter, dan nilai-nilai budaya yang teinsersi di dalam karya sastra. Pada intinya sebuah karya sastra adalah cermin budaya bangsa dan negara. Melalui sastra, kita dapat bercermin pada apa yang terjadi dalam sebuah budaya bangsa. Maka, pembelajaran sastra dalam mata kuliah sastra harus bersifat local-based dan character-based. Hal ini menjadi penting sebab pembelajaran bahasa adalah pembelajaran karakter dan budaya sekaligus. Ketika kita berbahasa maka sesungguhnya kita menyampaikan sebuah pesan dengan latar belakang budaya, nilainilai kepribadian dan konteks pemikiran yang kita miliki. Maka, sesungguhnya komunikasi melalui bahasa adalah komunikasi budaya. Budaya dan bahasa yang digunakan oleh penutur maupun yang tersampaikan kepada penerima, terjadi melalui serangkaian proses penerjemahan budaya. Jika komunikasi itu terjadi dengan efektif, bisa diasumsikan bahwa baik penutur maupun penerima memiliki latar belakang budaya yang sama, atau yang beresensi sama. Sebaliknya jika penerima tidak mampu menerima pesan yang disampaikan, salah satu faktor penyebabnya adalah adanya kesenjangan budaya.

Mata kuliah sastra di Jurusan Pendidikan Bahasa Inggris terbagi menjadi dua yakni literature 1 (prose fiction dan poetry) dan literature 2 (drama). Mata kuliah drama berbahasa Inggris selama ini menggunakan sumber-sumber yang didapat dari luar negeri, misalnya buku-buku, naskah, referensi dan rujukan lain. Namun ketika menyimak naskah-naskah tersebut, ada sebuah gap yang sangat lebar antara mahasiswa dan teks yang dibaca dan dimainkannya. Ada jurang yang sangat lebar antara mahasiswa dan teks. Jurang itu adalah adanya perbedaan budaya yang sangat mencolok antara satu budaya yang mereka miliki (budaya lokal Bali) dan budaya barat (Amerika dan Inggris). Naskah yang ditulis oleh orang luar, dengan konteks budaya luar yang rumit dan di luar jangkauan, kerap membuat mahasiswa kewalahan dalam menginterpretasi teks ke dalam konsep pemanggungan. Konsep yang sangat berbeda menyebabkan mahasiswa menghadapi kesulitan secara psikologis yang akhirnya menghalangi kematangan pencapaian prestasi mereka. Jika hal ini dibiarkan, maka dikhawatirkan mahasiswa akan kehilangan motivasi belajar dan mempengaruhi prestasi mereka.

Berdasarkan analisa kebutuhan melalui observasi dan wawancara yang dilakukan pada beberapa mahasiswa yang telah mengambil mata kuliah ini, didapatkan hasil bahwa mahasiswa memerlukan model pembelajaran sastra dan bahan ajar berbasis karakter dan lokalitas. Meskipun pembelajaran dalam mata kuliah drama sudah berjalan dengan baik dan efektif namun dapat lebih ditingkatkan dengan memberikan pengembangan model pembelajaran berbasis karakter dan lokalitas. Unsur karakter dan lokalitas sebagai cermin budaya bangsa belum nampak dalam pembelajaran di kelas. Mahasiswa berorientasi pada produk berupa pementasan berdasarkan naskah asing dan Jurnal Pendidikan Indonesia | 80 
pada akhirnya mahasiswa menjadi kehilangan akar budaya dan lokalitasnya sendiri. Karakter yang digali adalah karakterkarakter dunia barat yang memiliki persoalan-persoalan di luar jangkauan pengetahuan mahasiswa. Hal inilah membutuhkan sebuah solusi. Solusinya adalah mengembangkan model pembelajaran sastra dalam mata kuliah drama yang berbasis karakter dan lokalitas.

Pembelajaran berbasis sastra adalah pembelajaran berbasis karya narasi dan ekspositori sebagai bahan pendukung utama dalam pembelajaran yang menumbuhkembangkan literasi siswa (Sorensen dan Lehman, 1995). Sastra adalah sumber belajar utama. Karya sastra yang dimaksud dapat berupa puisi, prosa maupun drama. Karya sastra yang menjadi fokus dalam penelitian ini adalah naskah drama. Naskah drama adalah sebuah karya fiksi yang berpijak pada sebuah karakter dan segenap kompleksitasnya. Karakter dalam naskah ini kemudian diinterpretasikan, dinarasikan, lalu dipanggungkan dalam bentuk pementasan drama. Kompleksitas pemanggungan naskah dari yang sekedar naskah menjadi sebuah pementasan berangkat dari proses yang rumit. Pertama, pembacaan naskah. Kedua, interpretasi naskah. Ketiga, penentuan sudut pandang dan konsep pemanggungan. Keempat, pemanggungan. Maka, sesungguhnya proses selama terjadinya interpretasi hingga pemanggungan adalah proses pembelajaran sastra yang sebenarnya. Di dalam proses tersebut, ada pengenalan karakter, pengenalan konflik, dan penyelesaian konflik. Dengan sendirinya, karakter mahasiswa akan terbentuk melalui proses pembelajaran sastra.
Penelitian menunjukkan bahwa pembelajaran berbasis sastra (PBS) membantu siswa menjadi pembaca, penulis, dan pemikir yang baik. Aktivitas dalam pembelajaran berbasis sastra memungkinkan siswa menjadi pembaca, penulis, dan pemikir yang baik. Mereka menjadi pembaca, penulis, dan pemikir yang baik melalui proses pembelajaran yang mengedepankan kreativitas dan pengalaman nyata. Dalam proses pemanggungan naskah drama, juga terdapat pembelajaran bahasa yang sangat kompleks. Belajar bahasa melalui naskah drama memungkinkan siswa belajar secara natural dan tanpa sadar sehingga terjadilah proses pemerolehan bahasa. Siswa secara natural menikmati cerita dengan kejutankejutan dan imajinasi unik di dalamnya. Cerita adalah bahasa yang berbicara melalui pengalaman, dengan menggunakan kekayaan bahasa menceritakan pengalaman hidup yang bermakna. Dalam halnya membaca naskah drama, naskah adalah sebuah karya yang lahir dari pengalaman hidup pengarangnya dan sikap hidup pengarangnya terhadap sebuah persoalan. Naskah drama memberikan kemungkinan pembelajaran karakter yang lebih dalam dan lebih komprehensif sehingga pembelajaran karakter berjalan maksimal. Dalam penelitian ini fokus sastra yang dimaksud adalah sastra berbasis lokalitas.

Sastra berasal dari kata castra berarti tulisan. Dari makna asalnya dulu, sastra meliputi segala bentuk dan macam tulisan yang ditulis oleh manusia, seperti catatan ilmu pengetahuan, kitab-kitab suci, surat-surat, undang-undang, dan sebagainya (Ahira, 2010). Sastra dalam arti khusus yang kita gunakan dalam konteks kebudayaan, adalah ekspresi gagasan dan Jurnal Pendidikan Indonesia | 81 
perasaan manusia. Jadi, pengertian sastra sebagai hasil budaya dapat diartikan sebagai bentuk upaya manusia untuk mengungkapkan gagasannya melalui bahasa yang lahir dari perasaan dan pemikirannya.

$$
\text { Elangovan (2009) menemukan }
$$

bahwa sastra lokal telah memberikan latar belakang budaya yang memiliki kedekatan dengan mahasiswa. Sastra lokal memberikan nuansa karakter yang lebih dekat dengan mahasiswa sebab nilai-nilai yang terdapat di dalamnya adalah karakter yang mereka kenal sehari-hari atau dekat dengan budaya mereka. Hal ini juga bermakna bahwa pembelajaran kontekstual terjadi sebab setting, cerita dan karakter cerita dekat dengan kehidupan siswa. Teks dan konteks cerita telah bersatu dalam kehidupan siswa sehingga mereka tak terbebani dengan teks. Hal ini membuat siswa mudah memahami teks dan mudah menuliskan ide-idenya. Dalam konteks pembelajaran drama, pemanggungan naskah berbasis karakter dan lokalitas menjadi penting sebab naskah menjadi teks yang bebas diinterpretasikan dan diberi pemaknaan. Oleh karena naskah memiliki kedekatan kultural dengan pembacanya, maka pembaca merasa nyaman dengan teks dan mampu memahaminya dengan lebih mudah.

Tujuan penelitian ini adalah mengembangkan model pembelajaran drama berbasis karakter dan lokalitas serta mengembangkan bahan ajar drama berupa naskah drama berbasis karakter dan lokalitas.

\section{METODE}

Jenis penelitian ini adalah Research and Development (R and D). Penelitian ini memiliki definisi sebagai sebuah proses atau langkah-langkah untuk mengembangkan suatu produk baru atau menyempurnakan produk yang telah ada. Menurut Borg and Gall (1983 dalam Dewi, 2010), research and development is a process used to develop and validate educational products.

Subjek penelitian ini adalah mahasiswa yang sudah mengambil mata kuliah drama maupun yang sedang mengambil mata kuliah drama, beserta dosen pengampu mata kuliah drama di Jurusan Pendidikan Bahasa Inggris Universitas Pendidikan Ganesha pada tahun ajaran 2011/2012 dan 2012/2013. Objek penelitian adalah pengembangan model dan bahan pembelajaran mata kuliah drama di Jurusan Pendidikan Bahasa Inggris Universitas Pendidikan Ganesha. Lokasi penelitian adalah di Jurusan Pendidikan Bahasa Inggris Universitas Pendidikan Ganesha.

Desain penelitian menggunakan desain pengembangan Dick, Carey and Carey (2001 dalam Dewi, (2010)) yang berorientasi pada pengetahuan dan hasil. Model Dick, Carey and Carey terdiri dari 9 langkah. Setiap langkah sangat jelas maksud dan tujuannya sehingga bagi perancang pemula sangat cocok sebagai dasar untuk mempelajari model desain yang lain. Kesembilan langkah pada model Dick, Carey and Carey menunjukan hubungan yang sangat jelas, dan tidak terputus antara langkah yang satu dengan yang lainya. Dengan kata lain, system yang terdapat pada Dick and Carey sangat ringkas, namun isinya padat dan jelas dari satu urutan ke urutan berikutnya. Langkah-langkah desain pembelajarannya adalah sebagai berikut:

a. Mengidentifikasikan tujuan umum pembelajaran, dimana tahap ini bertujuan untuk menentukan tujuan

Jurnal Pendidikan Indonesia | 82 
pembelajaran dalam hal ini adalah perkuliahan drama

b. Melaksanakan analisis pembelajaran, dimana tahap ini bertujuan untuk menentukan tahaptahap pembelajaran yang penting untuk dilaksanakan di perkuliahan

c. Mengidentifikasi tingkah laku masukan dan karakteristik siswa, dimana tahap ini dilakukan untuk mengetahui karakteristik peserta perkuliahan dan mengetahui minat dan bakat mereka sehingga memudahkan mengarahkan ke tujuan pembelajaran

d. Merumuskan tujuan performansi, dimana tahap ini dilakukan untuk mengetahui rumusan evaluasi produk yaitu berupa performance (drama), hal ini akan menjadi acuan untuk penilaian karya mahasiswa

e. Mengembangkan butir-butir tes acuan patokan, adalah tahap dimana aspek-aspek evaluasi dinilai dan dikembangkan

f. Mengembangkan strategi pembelajaran adalah tahap untuk memilih dan menentukan serta mengembangkan strategi pembelajaran

g. Mengembangkan dan memilih materi pembelajaran, dimana tahap ini dilakukan untuk menyesuaikan materi dan tujuan pembelajaran

h. Mendesain dan melaksanakan evaluasi formatif, dimana tahap ini dilakukan untuk mengetahui hasil pembelajaran ketika pembelajaran masih berlangsung dalam satu semester misalnya tes tengah semester i. Merevisi bahan pembelajaran, untuk meningkatkan efektivitas pembelajaran

Penelitian riset dan pengembangan ini adalah jenis penelitian yang mixed antara metode penelitian kualitatif dan kuantitatif. Metode penelitian kualitatifnya berada pada tahap awal pengembangan yaitu survai dan pengumpulan data awal tentang sebuah kondisi yang ingin dibidik. Sedangkan penelitian kuantitatifnya bertugas menguji validitas produk dan reliabilitas produk. Untuk mengumpulkan data survai, dibutuhkan informasi tentang tujuan pembelajaran, proses pembelajaran, karakteristik warga belajar dan lingkungannya, tujuan khusus. Informasi tentang tujuan pembelajaran didapatkan dari analisis dokumen yaitu analisis silabus. Silabus yang digunakan adalah silabus berbasis kompetensi. Silabus berbasis kompetensi ini memuat tujuan pembelajaran, kompetensi standar, kompetensi dasar, indikator pembelajaran, proses pembelajaran, alokasi waktu dan asesmen. Untuk memperoleh data tentang efektifitas pembelajaran drama, materi pembelajaran drama, proses pembelajaran drama, model pembelajaran drama, nilai karakter dan asesmen tersebut digunakan teknik observasi, wawancara dan kuesioner. Instrumen yang digunakan adalah field note (catatan lapangan), panduan wawancara, kuesioner, dan asesmen diri.

Observasi dilakukan untuk mengetahui secara langsung apa yang terjadi di dalam perkuliahan, proses pembelajaran yang terjadi, serta model-model pembelajaran dan bahan ajar yang digunakan. Observasi dilakukan pada perkuliahan drama dan proses pra produksi pementasan drama sebagai tugas akhir di Jurusan Pendidikan Jurnal Pendidikan Indonesia | 83 
Bahasa Inggris semester $\mathrm{V}$ tahun ajaran 2012-2013.

Wawancara dilakukan untuk menggali informasi tentang apa yang dibutuhkan dosen khususnya dalam memasukkan unsur-unsur karakter dan lokalitas dalam model pembelajaran. Tokoh-tokoh yang diwawancarai adalah Prof. Drs Sunayono Basuki, Ks., MA, seorang guru besar sastra. Beliau telah mengajar mata kuliah drama di Universitas Pendidikan Ganesha selama puluhan tahun dan membimbing pementasan drama sebagai tugas akhir. Tokoh kedua yang diwawancarai adalah Drs. Hardiman, M.Si. Beliau adalah dosen seni rupa Universitas Pendidikan Ganesha yang juga menjadi sutradara dan pembimbing UKM Teater Kampus Seribu Jendela Universitas Pendidikan Ganesha. Selain wawancara dengan kedua tokoh tersebut, juga dilakukan asesmen diri karena peneliti adalah pengajar mata kuliah drama Jurusan Pendidikan Bahasa Inggris Undiksha.

Sementara itu kuesioner dilakukan untuk mengetahui respon mahasiswa terhadap proses pembelajaran. Untuk itu, dilakukan pengumpulan data dari mahasiswa untuk memberi masukan tentang nilai-nilai karakter dan lokalitas yang dibutuhkan dari model pembelajaran dan bahan pembelajaran. Kuesioner ini disebar kepada mahasiswa yang telah mengambil mata kuliah drama. Butir-butir dalam kuesioner ini meliputi efektifitas pembelajaran, materi pembelajaran, proses dan model pembelajaran, nilai-nilai karakter dan asesmen yang dilakukan. Sementara itu disebarkan pula kuesioner kedua untuk mengetahui efektivitas materi pembelajaran yang diberikan yaitu naskah yang akan dipentaskan. Mahasiswa yang disasar dalam kuesioner ini adalah mahasiswa yang sedang mengambil mata kuliah drama di semester V jurusan Pendidikan Bahasa Inggris tahun ajaran 2012-2013. Kuesioner pertama menggunakan skala Likert (sangat tidak setuju-sangat setuju) dengan skala 1-5 sedangkan kuesioner kedua menggunakan skala Likert 1-3.

\section{HASIL DAN PEMBAHASAN}

Hasil penelitian meliputi hasil analisis dokumen dan literatur, hasil wawancara, hasil asesmen diri, hasil observasi, dan hasil kuesioner. Hasil analisis dokumen dan literatur adalah sebagai berikut. Tujuan umum pembelajaran drama ada dua. Pertama, untuk membangun pengetahuan. Kedua, untuk membangun pengalaman.

Tujuan pertama, membangun pengetahuan drama, dijabarkan sebagai berikut.

- Untuk mengetahui konsep teater, dan ciri-ciri teater

- Untuk mengetahui elemen-elemen teater dan hubungan mereka

Tujuan kedua, memberikan pengalaman nyata berteater dengan memaksimalkan pengetahuan kognitif yang telah dikuasai. Analisis silabus menunjukkan bahwa pembelajaran drama berorientasi pada pengetahuan dan hasil pengalaman. Hasil ini diperkuat dengan hasil wawancara Prof. Basuki yang mengatakan sebuah pembelajaran drama yang baik, setidaknya bertumpu pada tiga kekuatan. Pertama, kekuatan konsep. Kedua, estetika naskah dan pementasan. Ketiga, karakter. Kekuatan konsep dapat dipelajari, dapat dieksplorasi pada teori-teori drama. Estetika naskah dan pemanggungan juga sesungguhnya lahir dari kekuatan konsep. Tanpa kekuatan konsep, sebuah naskah dan pementasan 
tidak dapat digarap. Demikian halnya dengan kekuatan karakter. Kekuatan karakter tak akan muncul jika pemain tak memahami konsep. Karakter juga dapat berkembang jika pemain teater memiliki kekuatan dan pengetahuan psikologis untuk mampu membawakan peran dengan baik. Jika karakter sudah dapat dikemas dengan baik, maka muncul nilai-nilai positif karakter yang tumbuh. Misalnya dengan berperan sebagai karakter yang baik, maka si pemeran karakter tersebut akan mendapatkan inspirasi untuk melakukan yang baik.

Wawancara kedua dilakukan terhadap ahli drama dan seni rupa, Drs. Hardiman, M.Si. Hasil wawancara dengan Drs. Hardiman, M.Si adalah sebagai berikut. Proses pembelajaran drama dapat dibagi menjadi dua yaitu soal apa itu bermain drama, dan bagaimana mengajarkan drama. Pengertian pertama yaitu apa bermain drama menyangkut definisi beberapa teori, konsep, model-model pendekatan drama. Pengertian kedua yaitu bagaimana mengajarkan drama dengan sangat menarik yang menyangkut proses pembelajaran kuliah drama termasuk proses produksi pementasan drama. Target pengajaran drama adalah untuk mempersiapkan mereka sebagai karakter yang bernas, sekaligus mempersiapkan mereka menjadi calon pendidik, baik secara formal maupun informal.

Hasil asesmen diri adalah sebagai berikut. Pertama, efektifitas pembelajaran ditentukan oleh kualitas proses pembelajaran. Selama ini proses pembelajaran sudah berjalan efektif namun perlu ditingkatkan. Misalnya perlu kombinasi antara proses belajar individu dan kelompok. Demikian pula perlu kombinasi antara ceramah dosen dan presentasi mahasiswa. Sebab tanpa adanya metode ceramah dari dosen, mahasiswa akan lebih sulit memahami pembelajaran. Kedua, materi pembelajaran sulit dipahami, sebab terdapat jurang budaya yang lebar antara teks dengan mahasiswa. inilah yang mesti diperbaiki. Materi dapat disederhanakan dengan penjelasan dosen. Naskah drama juga dikaji ulang agar tidak menggunakan naskah luar, namun dosen mengembangkan naskah sendiri dengan basis karakter dan lokalitas. Ketiga, nilai-nilai karakter harus dimasukkan dalam proses pembelajaran dan dalam asesmen pembelajaran. Dengan demikian maka asesmen tidak hanya berorientasi pada produk, namun juga pada proses.

Sementara itu hasil observasi menunjukkan bahwa karakteristik pebelajar mata kuliah drama sangat beragam. Mereka datang dari berbagai latar budaya daerah masing-masing dan mereka tidak memiliki dasar seni drama dalam bahasa Inggris. Pengetahuan dan pengalaman yang minim menyulitkan mereka beradaptasi dengan baik sebab mereka juga jarang bersentuhan dengan dunia seni. Tantangan dosen adalah menjembatani kendala bahasa dan budaya. Caranya adalah dengan mengembangkan model pembelajaran drama berbasis karakter dan lokalitas dan mengembangkan naskah drama berbasis karakter dan lokalitas.

Sementara itu hasil analisis kuesioner dibagi menjadi lima bagian yaitu: efektivitas mata kuliah drama, materi pembelajaran kuliah drama, proses pembelajaran dan model pembelajaran, nilai-nilai karakter yang dikembangkan dan asesmen. Kuesioner ini telah diuji validitas dan reliabilitasnya dan ada tiga butir yang gugur dalam uji validitas.

Jurnal Pendidikan Indonesia | 85 
Hasil kuesioner dari kelima butir besar tersebut adalah sebuah kebutuhan akan perkuliahan drama yang berdasarkan butir sebagai berikut.

1. Mata kuliah drama memberikan pengetahuan dasar drama, teori dan pengalaman memproduksi drama

2. Pemahaman mahasiswa terhadap kuliah drama hingga kemampuan memproduksi pementasan drama adalah memuaskan

3. Mata kuliah drama memberi kesempatan belajar teori drama dan praktik drama secara seimbang

4. Indikator pembelajaran terukur efektif melalui tugas, middle test dan final project berupa pementasan

5. Perkuliahan berlangsung tepat waktu dan efektif

6. Sumber belajar tersedia dengan baik dan terakses dengan baik (buku ajar, media online, dan video pementasan drama)

7. Asesmen terhadap proses pembelajaran berlangsung dengan efektif dan objektif

8. Perkuliahan drama membangun karakter kuat ke dalam diri mahasiswa dan ke luar (bersosialisasi dengan teman)

9. Perkuliahan drama membangkitkan sensitivitas terhadap karakter manusia dan kebudayaannya

10. Pengembangan karakter saling menghargai pendapat teman tumbuh dalam suasana diskusi di kuliah

11. Materi berbasis karakter dan lokalitas

12. Materi berhubungan dengan kehidupan sehari-hari

13. Materi sesuai dengan tingkat kemampuan mahasiswa

14. Proses pembelajaran berlangsung dengan demokratis
15. Proses

pembelajaran mengkombinasikan ceramah dan diskusi

16. Model pembelajaran berorientasi pada karakter dan lokalitas

17. Model pembelajran berorientasi pada proses

18. Nilai-nilai karakter yang harus dikembangkan dalam pembelajaran drama antara lain jujur, ingin tahu, kreatif, mandiri, bertanggung jawab, demokratis, suka membaca, peduli lingkungan dan peduli sosial.

19. Asesmen bersifat terbuka dan objektif

20. Asesmen berorientasi pada proses dan produk.

Setelah mendapatkan hasil-hasil di atas, tahapan penelitian selanjutnya adalah sebagai berikut.

1. Merumuskan tujuan performansi, dimana tahap ini dilakukan untuk mengetahui rumusan evaluasi produk yaitu berupa tes evaluasi kognitif dan tes performance (drama) dimana hal ini akan menjadi acuan untuk penilaian karya mahasiswa. Produk mata kuliah adalah sebuah pementasan drama dan dievaluasi dalam bentuk rubrik penilaian penampilan

2. Mengembangkan butir-butir tes acuan patokan, adalah tahap dimana aspek-aspek evaluasi dinilai dan dikembangkan. Butir butir test acuan patokan ini diujikan dan dijadikan bahan evaluasi perbaikan selanjutnya

3. Mengembangkan strategi pembelajaran adalah tahap untuk memilih dan menentukan serta mengembangkan strategi pembelajaran

Jurnal Pendidikan Indonesia | 86 
4. Strategi pembelajaran yang dipilih adalah yang sesuai dengan karakteristik pembelajaran dan karakteristik pembelajaran drama yaitu pembelajaran berbasis karakter dan lokalitas

5. Mengembangkan dan memilih materi pembelajaran, dimana tahap ini dilakukan untuk menyesuaikan materi dan tujuan pembelajaran

6. Mendesain dan melaksanakan evaluasi formatif, dimana tahap ini dilakukan untuk mengetahui hasil pembelajaran ketika pembelajaran masih berlangsung dalam satu semester misalnya tes tengah semester dan tes akhir semester

7. Merevisi pembelajaran, untuk meningkatkan efektivitas pembelajaran.

Sesuai dengan tujuan umum pembelajaran mata kuliah drama, ada dua tujuan performansi yang dibutuhkan. Pertama, performansi pengetahuan konsep. Kedua, performansi pertunjukan drama. Jadi rumusan evaluasi produknya juga ada dua yaitu tes kognitif dan pertunjukan. Setelah itu butir-butir acuan patokan dikembangkan berdasarkan kompetensi dasar, indikator, dan materi pembelajaran. Setelah pengembangan butir-butir acuan patokan, tahap selanjutnya adalah mengembangkan strategi pembelajaran. Strategi pembelajaran yang sesuai dengan analisis kebutuhan adalah strategi pembelajaran yang berbasis karakter dan lokalitas.

Adapun sintaks pembelajarannya adalah sebagai berikut.

a. Membaca dan memahami teori drama

b. Memahami konsep drama berbasis karakter dan lokalitas c. Mengapresiasi karya sastra dengan membaca dan memahami karya sastra berbasis karakter dan lokalitas (naskah drama)

d. Merespon karya sastra berbasis karakter dan lokalitas tahap pertama (menghayati karakter dalam naskah drama)

e. Merespon karya sastra berbasis karakter dan lokalitas tahap kedua (mementaskan naskah drama)

Setelah mengembangkan strategi pembelajaran, langkah selanjutnya adalah mengembangkan materi pembelajaran. Pengembangan materi pembelajaran berpusat pada pembuatan naskah drama berbasis karakter dan lokalitas. Adapun kriteria naskah adalah segi kebahasaan, segi isi, karakter dan lokalitas serta keterbacaan naskah. Ujicoba keefektivitasan bahan ajar naskah dilakukan kepada mahasiswa dengan menyebarkan kuesioner tentang bahan ajar naskah. Kuesioner ini khusus membahas tentang bahan ajar naskah drama saja.

Mengingat hasil kuesioner menunjukkan presentasi yang signifikan yaitu $90-100 \%$ maka dapat diasumsikan bahwa naskah dapat dibaca dan dipahami oleh mahasiswa dan naskah mengandung nilai-nilai karakter dan lokalitas yang dibutuhkan.

Tahap selanjutnya adalah melaksanakan evaluasi formatif. Tes yang digunakan sebelumnya diujicobakan untuk menguji validitas dan reliabilitasnya. Setelah tes dinyatakan valid dan reliabel, maka tes ini digunakan untuk menguji efektivitas pembelajaran. Ada dua kelas yang dibandingkan yaitu kelas yang tidak diberi pengajaran pembelajaran drama berbasis karakter (kelas A) dan kelas yang diberi Jurnal Pendidikan Indonesia | 87 
pembelajaran berbasis karakter dan lokalitas (kelas B).

Dari analisis statistik deskriptif, didapatkan data bahwa nilai rata-rata kelas B (86.50) jauh lebih baik dari kelas A (80.00). Untuk uji t, dilakukan tes homogenitas dan normalitas. Data dikatakan normal jika nilai signifikansi Kolmogorov Smirnov melebihi 0.05. menurut tabel di atas, nilai signifikansinya adalah 0.06 dan 0.075 . Artinya angka tersebut melebihi 0,05 . Dengan demikian dapat dikatakan bahwa data berdistribusi normal.

Varians kedua kelompok dikatakan homogen jika nilai signifikansi Uji Levene melebihi 0.05. Berdasarkan tabel, nilai signifikansi Uji Levene adalah 0.407 atau melebihi 0.05 . Hal ini berarti varians kedua kelompok bersifat homogen. Grafik kedua kelas dapat dilihat sebagai berikut.

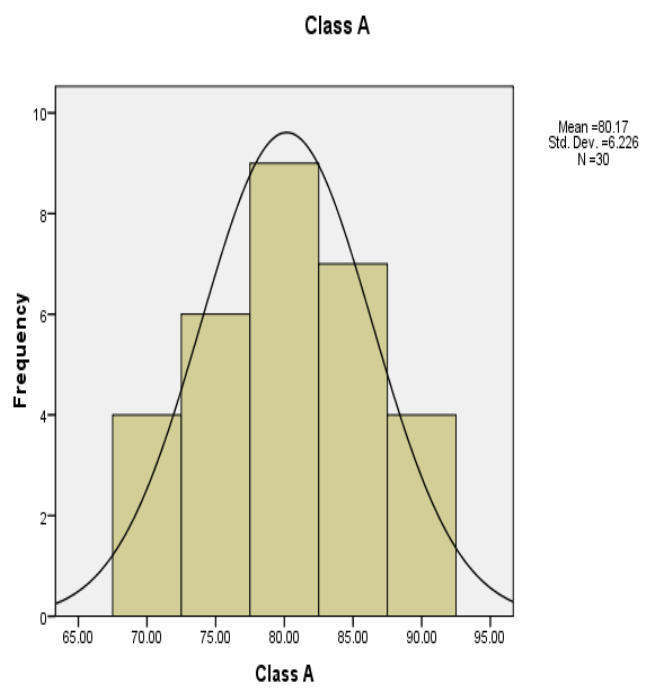

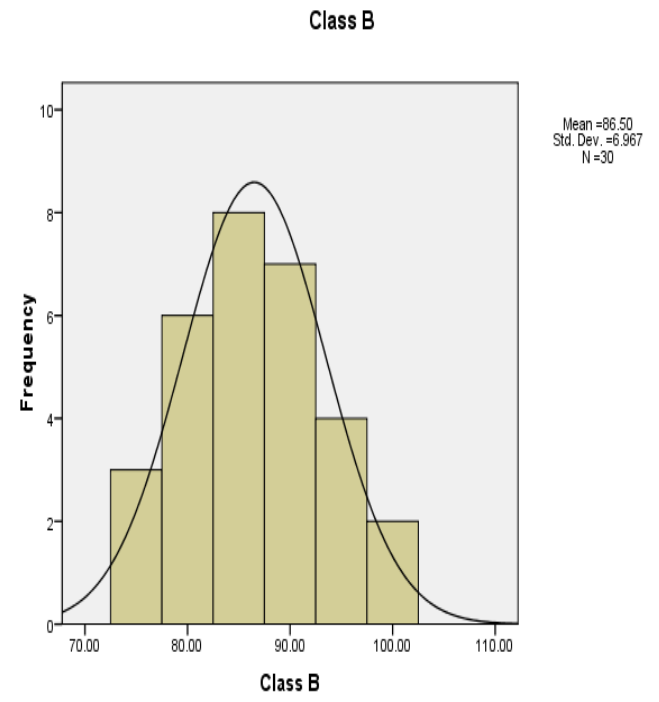

Selanjutnya hasil uji t untuk mengetahui perbedaan signifikansi kedua kelompok dapat dilihat dari tabel nilai t-test. Nilai signifikansi yang diperoleh adalah 0.000 . Nilai signifikansi tersebut lebih rendah dari 0.05 sehingga dapat dikatakan bahwa ada perbedaan yang signifikan antara kedua kelompok mahasiswa. Kelompok mahasiswa yang diajarkan dengan model pembelajaran sastra lebih baik daripada kelompok mahasiswa yang tidak diajarkan dengan model pembelajaran drama. Hal ini dapat dilihat dari perbedaan rata-rata nilai yang diraih kedua kelompok. Kelompok B memiliki rata-rata nilai jauh lebih tinggi daripada kelompok $A$.

Dengan diujinya efektifitas pembelajaran ini maka simpulan sederhana yang dapat kita buat adalah bahwa pembelajaran berbasis sastra, karakter dan lokalitas sangat efektif diimplementasikan pada mata kuliah drama. Hal ini mendukung penelitian Piscayanti (2010) bahwa pembelajaran berbasis sastra mampu 
meningkatkan kemampuan mahasiswa untuk menjadi pembelajar yang lebih baik, bahkan menjadi pembaca dan penulis yang lebih baik. Dalam penelitian berikutnya Piscayanti (2011) juga menemukan bahwa pembelajaran berbasis sastra lokal lebih efektif meningkatkan kemampuan belajar mahasiswa menjadi penulis naratif. Dalam hal ini, pembelajaran drama menuntut mahasiswa bisa menjadi pembaca yang baik, pendengar yang baik dan perespon yang baik. Dengan bermain drama, mahasiswa mampu menjadi peran yang sebelumnya tak pernah ia bayangkan sebelumnya. Inilah yang membentuk karakter mahasiswa dengan lebih tangguh.

Tahapan berikutnya adalah merevisi pembelajaran. Merevisi pembelajaran dilakukan jika ada hal-hal yang perlu ditingkatkan atau hal-hal yang membutuhkan fokus dan penekanan. Dalam implementasi pembelajaran berbasis sastra, karakter dan lokalitas, beberapa hal yang perlu direvisi adalah sebagai berikut.

Pertama, pembelajaran berbasis sastra memerlukan lebih banyak sumber-sumber kontekstual tentang drama di Indonesia. Selama ini pembelajaran drama berbahasa Inggris lebih banyak bersumber dari materimateri impor dari luar negeri. Kecenderungan ini terjadi karena penulis teori-teori drama berbahasa Inggris berasal dari luar. Hal ini menyebabkan gap budaya yang sangat lebar antara mahasiswa dan materi. Mahasiswa tidak memiliki latar budaya yang ada dalam teks, sehingga mereka tidak memahami hal-hal yang bersifat konsep. Jika saja lebih banyak penulis Indonesia menulis konsep drama di Indonesia sesuai karakter dan lokalitas budaya, maka tentulah pembelajaran mata kuliah drama bahasa Inggris lebih mengakar pada masyarakat.
Kedua, bahan pembelajaran berupa naskah-naskah drama berbahasa Inggris yang ditulis oleh orang Indonesia. Oleh sebab itu peneliti mencoba menulis naskah drama berbahasa Inggris. Namun tentu saja hal ini masih ada di tahap yang kurang sempurna. Perlu diberikan kesempatan kepada pengampu mata kuliah drama untuk menulis naskah drama dan mengembangkan bahan-bahan ajar lainnya.

Dengan kedua revisi tadi, diharapkan ke depannya model pembelajaran berbasis sastra dapat berjalan lebih baik.

\section{SIMPULAN DAN SARAN}

Pertama, penelitian ini menunjukkan bahwa pembelajaran berbasis sastra, karakter dan lokalitas memiliki peluang besar untuk berkembang menjadi sesuatu yang lebih besar di masa depan. Pembelajaran berbasis sastra, karakter dan lokalitas mengandung akar budaya dan nilai-nilai karakter yang membumi. Dengan model pembelajaran berbasis sastra, karakter dan lokalitas, mahasiswa lebih memahami karakter dirinya dan karakter yang diperankannya.

Kedua, bahan ajar berupa naskah drama berbasis karakter dan lokalitas perlu diperkenalkan kepada mahasiswa agar mhasiswa lebih memahami karakter dan lokalitas budaya sendiri.

Saran-saran dalam penelitian ini adalah sebagai berikut.

Pertama, penelitian ini memerlukan penelitian lanjutan untuk mengembangkan model pembelajaran dan bahan pembelajaran berbasis sastra, karakter dan lokalitas dengan tema lebih beragam dan audiens yang lebih luas.

Kedua, hasil penelitian ini memerlukan sosialisasi untuk diperkenalkan kepada audiens yang lebih luas agar model Jurnal Pendidikan Indonesia | 89 
pembelajaran berbasis sastra, karakter dan lokalitas bisa diimplementasikan oleh sebanyak mungkin orang.

Ketiga, untuk menyasar audiens yang lebih luas, salah satu caranya adalah menerbitkan hasil-hasil penelitian ini dengan profesional. Penerbitan ini tentunya harus digarap khusus untuk menghasilkan buku bahan ajar berbasis sastra, karakter dan lokalitas yang berkualitas.

\section{DAFTAR PUSTAKA}

Ahira, A. 2010. Dasar-dasar Pengertian Sastra. www.anneahira.com (diunduh pada 5 Maret 2012)

Dewi, E.S., 2010. A Proposed Sillabus for TEYL Course for Students of English Education Department at Ganesha University of Education. Thesis belum dipublikasikan. Malang: Program Pascasarjana Universitas Negeri Malang.

Elangovan, S. 2009. Using Local Literatures and Translations to Teach English. Htttp;//www.articlesbase.com/literature -articles/using-local-literaturesandtranslations-to-teach-english1075560.html. (diunduh pada 20 Maret 2012).

Piscayanti, K.S. 2010. The Effect of Literature-Based Instruction on Student's English Achievement With Differing Achievement Motivation : An Experimental Study on The Eighth Grade Students of SMPN 1 Singaraja In Academic Year 2009-2010. Thesis belum dipublikasikan. Singaraja: Program Pascasarjana Universitas Pendidikan Ganesha Singaraja.

Piscayanti, K.S. 2011. Pengaruh Pembelajaran Berbasis Sastra Lokal (Bali) Terhadap Prestasi Menulis Naratif Bahasa Inggris Pada Mahasiswa Semester Empat Jurusan Pendidikan Bahasa Inggris Undiksha Tahun Ajaran 2010/2011. Laporan Penelitian belum dipublikasikan.
Singaraja: Lembaga Penelitian Undiksha.

Sorensen dan Lehman. 1995. Teaching with Children's Books. USA: National Council of Teachers of English. 


\title{
UPAYA PENGEMBANGAN SOFT SKILLS MELALUI IMPLEMENTASI MODEL PEMBELAJARAN KOOPERATIF UNTUK PENINGKATAN AKTIVITAS DAN HASIL BELAJAR MAHASISWA PADA PEMBELAJARAN KIMIA DASAR
}

\author{
I Ketut Sudiana \\ Jurusan Pendidikan Kimia, Fakultas MIPA, Universitas Pendidikan Ganesha, \\ Singaraja, Indonesia
}

\begin{abstract}
Abstrak
Penelitian ini adalah penelitian tindakan kelas (PTK) yang bertujuan (1) meningkatkan aktivitas belajar mahasiswa pada pembelajaran Kimia Dasar, (2) meningkatkan hasil belajar mahasiswa pada pembelajaran Kimia Dasar, dan (3) mendeskripsikan persepsi mahasiswa terhadap upaya pengembangan soft skills melalui implementasi model pembelajaran kooperatif untuk peningkatan aktivitas dan hasil belajar mahasiswa pada pembelajaran Kimia Dasar. Subjek penelitian ini adalah mahasiswa Semester I (Kelas B) Jurusan Pendidikan Biologi FMIPA Universitas Pendidikan Ganesha Tahun akademik 2011/2012, yang mengikuti perkuliahan Kimia Dasar sebanyak 22 mahasiswa. Objek penelitian ini adalah upaya atau tindakan peningkatan soft skills mahasiswa yang diterapkan, kepemilikan atribut soft skills mahasiswa, persiapan belajar mahasiswa (tugas reviu), aktivitas mahasiswa dalam pembelajaran, hasil belajar mahasiswa, dan persepsi mahasiswa terhadap model pembelajaran yang diterapkan. Hasil penelitian menunjukkan bahwa tindakan yang diterapkan dalam penelitian ini dapat (1) meningkatkan soft skills mahasiswa, (2) meningkatkan aktivitas belajar mahasiswa, (3) meningkatkan hasil belajar mahasiswa, dan (4) mahasiswa memberikan respon positif terhadap upaya pengembangan soft skills yang dimplementasikan melalui model pembelajaran kooperatif.
\end{abstract}

Kata kunci: Pengembangan soft skills, model pembelajaran kooperatif, Kimia Dasar

\begin{abstract}
This classroom action research aimed at (1) improving students' activities on Basic Chemistry subject, (2) improving student's achievement, (3) gaining students' perception towards the efforts of soft skills development by implementing cooperative learning model to improve students' activities and achievement on Basic Chemistry subject. The subjects of this research were all first semester students of class B (including 22 students) of Biology Education Department, Faculty of Mathematics and Science, Ganesha University of Education in the academic year 2011/2012. The objects of the research were the efforts of improving the students' soft skills, soft skill atribut ownership of the students, students learning preparation (review), students' activities during learning process, students' achievement, and students' perception towards the implemented model. The results of the study showed that the implementation of cooperative learning model were (1) improving the students' soft skills, (2) improving student's activities, (3) improving student's achievement, (4) student's positive response towards the efforts of soft skills development implemented through cooperative learning model.
\end{abstract}

Keywords: Soft skills development, cooperative learning model, Basic Chemistry 


\section{PENDAHULUAN}

Dalam konteks kehidupan bermasyarakat, berbangsa dan bernegara terjadi gejala anomali (sesuatu yang ganjil dan seharusnya tidak terjadi), seperti: (1) korupsi terjadi pada kaum terdidik, (2) pelanggaran hukum justeru dilakukan oleh aparat penegak hukum, (3) dunia olah raga yang seharusnya menjunjung tinggi nilainilai sportivitas sering dikotori praktik tidak terpuji mengatur score pertandingan dan dibarengi praktik suap, (4) anggota DPR dengan sebutan dewan terhormat sering menunjukkan perilaku tidak terhormat, (5) para pendidik berprilaku tidak terdidik dengan ikut terlibat praktek membocorkan soal atau kunci jawaban ujian nasional (UN), dan (6) pejabat yang menyalahgunakan jabatannya. Kejadian tersebut merupakan fenomena bukti ketertinggalan akibat dari kegagalan atau ketidaksempurnaan pendidikan, terutama pendidikan karakter.

Pendidikan karakter di sekolah merupakan kebutuhan vital agar generasi penerus dapat dibekali dengan kemampuankemampuan dasar yang tidak saja mampu menjadikannya life-long learners sebagai salah satu karakter penting untuk hidup di era informasi yang bersifat global, tetapi juga mampu berfungsi dengan peran serta yang positif. Untuk itu harus dilakukan upaya-upaya instrumental untuk meningkatkan keefektifan proses pembelajarannya disertai pengembangan kultur yang positif (Darmiyati Zuchdi, dkk. 2010: 1)

Pendidikan sebagai usaha sadar manusia untuk memanusiakan manusia ke arah yang lebih baik kurang berhasil atau dengan kata lain gagal. Salah satu penyebabnya adalah akibat dari pergeseran makna pendidikan ke arah pengajaran. Sekarang ini proses pembelajaran "kering" dengan transaksi pendidikan nilai (transformation of value), dan lebih menitikberatkan pada aspek pengetahuan (transformation of knowledge), atau dengan kata lain pendidikan kita lebih menekankan aspek teknis atau keterampilan keras (hard skills), kurang menekankan keterampilan lunak (soft skills). Sejalan dengan hal ini, Baedowi, Direktur Jenderal PMPTK Depdiknas, sebagaimana dikutip Triatmanto (2010), menyatakan bahwa saat ini ada kecenderungan masyarakat maupun sekolah sekadar memacu siswa untuk memiliki kemampuan akademik tinggi tanpa diimbangi pembentukan karakter yang kuat dan cerdas. Upaya sekolah maupun orang tua agar murid atau anaknya mencapai nilai akademis tinggi sangat kuat, tapi mengabaikan hal-hal yang non akademis.

Walaupun kondisi sebagaimana dipaparkan di atas sudah menjadi pengetahuan atau "rahasia umum", dan bahkan sudah menjadi keprihatinan banyak pihak, akan tetapi belum banyak tindakan nyata yang diarahkan untuk memperbaiki kondisi tersebut. Kegiatan pendidikan di sekolah dan kegiatan pembelajaran oleh guru di kelas, belum secara terprogram dan terstruktur memasukkan aspek soft skills dalam kegiatan belajar mengajar. Sadar atau tidak, sesungguhnya sedikit saja metode pembelajaran diperbaiki, bisa saja menghasilkan hasil pembelajaran yang dahsyat (Elfindri, dkk. 2010: 9). Dalam penelitian ini pembelajaran akan diperbaiki dengan metode pembelajaran yang memberikan peluang pengembangan soft skills anak didik.

Soft skills didefinisikan sebagai "personal and interpersonal behaviours that develop and maximize human performance (e.g. coaching, team building, initiative, decision making, etc). soft skills does not include Jurnal Pendidikan Indonesia | 92 
technical skills such as financial, computing and assembly skills " (Berthal dalam Illah Sailah, 2007).

Dari penelusuran atau kajian formal yang pernah dilakukan, ditemukan yang membawa atau mempertahankan orang di dalam sebuah kesuksesan $80 \%$ ditentukan oleh soft skills yang dimilikinya dan $20 \%$ oleh hard skillsnya (Illah Sailah, 2007). Sejalan dengan pernyataan tersebut maka kesuksesan mahasiswa dalam mengikuti perkuliahan juga ditentukan oleh faktor soft skills selain hard skills (potensi akademiknya). Untuk meningkatkan soft skills mahasiswa salah satunya dapat ditempuh dengan cara mensinergikan antara soft skills dan hard skills dalam perkuliahan.

Pengembangan soft skills dapat dilakukan melalui proses pembelajaran (intrakurikuler) dan kegiatan kemahasiswaan (ekstrakurikuler). Pengembangan soft skills melalui kegiatan belajar atau tatap muka di dalam kelas memerlukan kreativitas dosen pengampu mata kuliah dengan tetap pada pencapaian kompetensi mata kuliah tersebut. Pengembangan soft skills melalui kurikulum dapat ditempuh dengan dua cara. Pertama, melalui kegiatan pembelajaran yang secara ekplisit diintegrasikan dalam mata kuliah yang dituangkan dalam Silabus, SAP (Satuan Acara Perkuliahan) atau RPP (Rencana Pelaksanaan Pembelajaran). Kedua, dapat dilakukan melalui proses hidden curriculum, yaitu suatu strategi pengembangan soft skills yang disampaikan oleh dosen kepada mahasiswa secara terintegrasi pada saat perkuliahan berlangsung. Biasanya, cara kedua ini dilakukan dosen melalui panutan (contoh atau teladan), dan juga melalui pesanpesan selingan pada saat pelaksanaan perkuliahan menggunakan kata-kata mutiara, lagu-lagu, pribahasa, cerita, film (video clip), yang memotivasi dan inspiratif, dan tidak kalah penting adalah peran pimpinan (dosen) sebagai role model (Sriartha dan Sudiana, 2009: 6).

Dalam pembelajaran kooperatif siswa belajar dalam kelompok-kelompok kecil yang memiliki tingkat kemampuan berbeda. Dalam menyelesaikan tugas kelompok, setiap anggota saling bekerja sama dan membantu untuk memahami suatu bahan pembelajaran. Belajar belum selesai jika salah satu teman dalam kelompok belum menguasai bahan pembelajaran (Budi Jatmiko, 2004:7). Sebagaimana pembelajaran inovatif pada umumnya pembelajaran kooperatif bertujuan untuk meningkatkan prestasi belajar anak. Siswa akan belajar lebih efisien dalam proses pembelajaran kelompok ( $\mathrm{Te}-\mathrm{Yi}$ Chan, et al: 2008). Simon Attle dan Bob Baker (2007) juga menemukan bahwa melalui pembelajaran kooperatif siswa dapat memaksimalkan perkembangan profesional mereka. Selain itu, pembelajaran kooperatif masih memiliki keunggulan lain, yaitu banyak atribut soft skills dapat dilatihkan, seperti kerjasama (teamwork), keterampilan berkomunikasi, pengambilan keputusan, disiplin, manajemen waktu, kejujuran dan lain sebagainya.

Bersadarkan

pengalaman

memberikan kuliah Kimia Dasar di Jurusan Pendidikan Biologi FMIPA Undiksha, ditemukan beberapa kelemahan dalam pembelajaran, seperti (1) pelaksanakan perkuliahan belum dikelola dengan memperhatikan atau memberikan tempat pada aspek sosial pembelajaran, (2) umumnya mahasiswa cenderung belajar, bekerja, dan juga memecahkan permasalahan-permasalahan pembelajaran 
yang mereka hadapi sendiri-sendiri, (3) mahasiswa kurang terbiasa bekerja sama (sharing) dengan mahasiswa lainnya, (4) mahasiswa sering mengeluh jika diberikan tugas atau PR (Pekerjaan Rumah), (5) tidak disiplin atau suka menunda-nunda dalam mengerjakan tugas, yang dikalangan mahasiswa dikenal dengan istilah SKS (Sistem Kebut Semalam), dan (6) ketidakjujuran mengerjakan tugas, antara lain menyalin (copy paste) pekerjaan teman. Fakta ini memberikan indikasi bahwa soft skills mahasiswa masih rendah. Hal ini dapat menghambat pencapaian puncak prestasi akademiknya. Dosen harus memiliki pedagogi soft skills untuk tujuan meningkatkan soft skills mahasiswa.

Perlu dikondisikan pengelolaan pembelajaran yang memberikan peluang terjadi interaksi dan kerjasama antara mahasiswa satu dengan lainnya. Hampir semua siswa belajar lebih efisien pada saat mereka diperkenalkan untuk bekerja secara bersama-sama (cooperative) dengan siswa lainnya dalam satu kelompok atau tim. Menurut Vygotsky, interaksi sosial dengan teman lain memacu terbentuknya ide baru dan memperkaya perkembangan intelektual siswa (Ibrahim dan Nur., 2000:18). Ide kunci dari Vygotsky tentang aspek sosial belajar adalah konsepnya tentang zone of proximal development (zone perkembangan terdekat). Untuk mencapai zona perkembangan terdekat, perlu diciptakan lingkungan sosial belajar siswa agar tercipta masyarakat belajar (learning community). Model pembelajaran yang dapat menciptakan kondisi seperti itu adalah model pembelajaran kooperatif.

Berdasarkan uraian di atas agar terjadi peningkatan kualitas pembelajaran (aktivitas dan hasil belajar mahasiswa), dapat dilakukan melalui upaya peningkatan soft skills mahasiswa. Model pembelajaran yang memberi peluang paling tinggi terjadinya peningkatan soft skills adalah pembelajaran kooperatif. Oleh karena itu dalam penelitian ini dirumuskan judul "Upaya Pengembangan Soft skills Melalui Implementasi Model Pembelajaran Kooperatif untuk Peningkatan Aktivitas dan Hasil Belajar Mahasiswa pada Pembelajaran Kimia Dasar".

Adapun permasalahan dalam penelitian ini dapat dirumuskan sebagai berikut. (1) Apakah upaya pengembangan soft skills melalui implementasi model pembelajaran kooperatif dapat meningkatkan aktivitas belajar mahasiswa pada pembelajaran Kimia Dasar?, (2) Apakah upaya pengembangan soft skills melalui implementasi model pembelajaran kooperatif dapat meningkatkan hasil belajar mahasiswa pada pembelajaran Kimia Dasar?, dan (3) Bagaimanakah persepsi mahasiswa terhadap upaya pengembangan soft skills melalui implementasi model pembelajaran kooperatif pada pembelajaran Kimia Dasar?

Tujuan umum penelitian ini adalah (1) meningkatkan aktivitas belajar mahasiswa pada pembelajaran Kimia Dasar, (2) meningkatkan hasil belajar mahasiswa pada pembelajaran Kimia Dasar, dan (3) mengetahui persepsi mahasiswa terhadap upaya pengembangan soft skills melalui implementasi model pembelajaran kooperatif untuk peningkatan aktivitas dan hasil belajar mahasiswa pada pembelajaran Kimia Dasar. Penerapan model pembelajaran ini diharapkan dapat bermuara pada terjadinya peningkatan soft skills mahasiswa yang memberi dampak meningkatkan aktivitas dan hasil belajar mahasiswa. 
Model pembelajaran dapat membantu guru untuk mencapai tujuan pembelajaran yang berdimensikan sosial dan hubungan antar manusia. Belajar secara kooperatif dikembangkan berdasarkan teori belajar kognitifkonstruktivis dan teori belajar sosial. Gagasan dalam kerja kooperatif memberikan penekanan kegunaanya pada pencapaian tujuan dan kesuksesan kelompok, dimana keberhasilan belajar dicapai hanya jika seluruh anggota kelompok mencapai tujuan pembelajarannya (Slavin, Robert E., 1995:5). Keberhasilan dalam belajar bukan semata-mata harus diperoleh dari guru, melainkan bisa juga dari pihak lain yang terlibat dalam pembelajaran itu, yaitu teman sebaya (Hilda Karli dan Margaretha Sriyuliariatiningsih, 2002). Tujuan dibentuk kelompok kecil dalam implementasi model pembelajaran kooferatif adalah untuk memberi kesempatan yang sama kepada semua mahasiswa yang terlibat secara aktif dalam kegiatan belajar (Suryanti, 1998). Menurut Johnson dan Johnson, ada lima unsur pokok yang harus diperhatikan dalam pembelajaran kooperatif, yaitu (1) saling ketergantungan yang positif, (2) peningkatan interaksi antarsiswa, (3) peningkatan tanggung jawab individu, (4) pembentukan keterampilan dan kemampuan sosial, (5) proses kelompok, yaitu terjadi hubungan kerjasama yang efektif. (Ballanca, James, 1995).

\section{METODE PENELITIAN}

Subjek dari penelitian ini adalah mahasiswa Semester I (Kelas B) Jurusan Pendidikan Biologi FMIPA Universitas Pendidikan Ganesha Tahun akademik 2011/2012, yang mengikuti perkuliahan Kimia Dasar sebanyak 22 mahasiswa. Objek penelitian ini adalah upaya atau tindakan peningkatan soft skills mahasiswa yang diterapkan, kepemilikan atribut soft skills mahasiswa, persiapan belajar mahasiswa (tugas reviu), aktivitas mahasiswa dalam pembelajaran, hasil belajar mahasiswa, dan persepsi mahasiswa terhadap model pembelajaran yang diterapkan. Penelitian ini mengambil desain penelitian tindakan kelas (PTK) menggunakan prosedur pembelajaran kooperatif STAD (Student Teams Achievement Division).

\section{Tindakan Siklus I}

Tindakan pada siklus I terdiri dari: (1) Pada awal perkuliahan, yaitu pada pertemuan untuk pertama kalinya, kepada mahasiswa diberikan SAP (Satuan Acara Perkuliahan) Kimia Dasar yang berisikan tentang: kompetensi standar, kompetensi dasar, indikator, materi pokok, dan sub materi pokok serta atribut soft skills yang ingin atau dapat dikembangkan, (2) Pembentukan kelompok, setiap kelompok terdiri dari 3-5 orang mahasiswa, bersifat heterogen berdasarkan kemampuan dan jenis kelamin, (3) Satu minggu sebelum perkuliahan pokok bahasan tertentu, kepada mahasiswa diberikan tugas membuat reviu pokok bahasan dan/atau tugas lainnya, (4) Setiap kali perkuliahan diberikan tindakan berupa pengembangan soft skills mahasiswa yang dilakukan oleh dosen. Alternatif strategi pengembangan soft skills yang dapat dilakukan seperti lagu-lagu, testimoni, cerita inspiratif, gambar, video clip, dengan durasi antara 5-7 menit, (5) Perkuliahan diselenggarakan dengan presentasi hasil reviu pokok bahasan dan/atau tugas oleh kelompok mahasiswa dilanjutkan dengan diskusi, (6) Setelah presentasi dan diskusi akan lahir permasalahan atau pertanyaan-pertanyaan 
yang berasal dari mahasiswa ataupun dari dosen. Permasalahan dan pertanyaan dikoleksi, untuk kemudian pada akhir pelaksanaan presentasi dan diskusi kepada mahasiswa diminta untuk menjawabnya (tugas individu). Karena pertimbangan waktu yang tersedia terbatas, maka untuk maksud ini dari sejumlah permasalahan atau pertanyaan yang muncul dipilih antara 3 sampai dengan 5 permasalahan/pertanyaan yang substansinya paling relevan dengan kompetensi dasar pokok bahasan yang sedang dikaji. Hasil pekerjaan mahasiswa dikumpulkan saat itu untuk kemudian dinilai. Nilai yang diperoleh mahasiswa menunjukkan tingkat perkembangan aktual mahasiswa, (7) Tugas (permasalahan dan pertanyaan) yang sama dengan point 5 di atas, kembali ditugaskan kepada mahasiswa untuk dikerjakan secara berkelompok di rumah sebagai PR (pekerjaan rumah), (8) Pertemuan berikutnya (seminggu kemudian) hasil pekerjaan mahasiswa secara berkelompok dikumpulkan untuk dinilai sebagai nilai kelompok. Nilai ini menunjukkan tingkat perkembangan terdekat bagi mahasiswa setelah dibantu teman sejawat. Berbagai hal yang masih belum dapat dikerjakan dalam kerja kelompok dapat ditanyakan kepada dosen untuk didiskusikan, (9) Pada setiap akhir siklus pembelajaran terdiri atas beberapa pokok bahasan (kompetensi dasar) dilaksanakan tes hasil belajar. Nilai tes yang dicapai mahasiswa akan menunjukkan tingkat perkembangan terdekat mahasiswa setelah pembelajaran dibantu teman sejawat dan dosen.

\section{Refleksi Tindakan I}

Berdasarkan hasil observasi dan evaluasi seperti disajikan di atas maka dapat dibuat refleksi tindakan I sebagai berikut. (1)
Aktivitas belajar mahasiswa siklus I: partisipasi dalam presentasi-diskusi kategori cukup; spontanitas mahasiswa dalam presentasi-diskusi kategori baik; dan antusiasme mahasiswa dalam presentasidiskusi adalah cukup. (2) Nilai tugas membuat reviu pokok bahasan baik. (3) Nilai perkembangan aktual mahasiswa kurang. (4) Nilai perkembangan terdekat baik. (5) Nilai tes akhir cukup. (6) Mahasiswa masih mengalami kesulitan dalam menjawab soalsoal yang menuntut penalaran dan argumentasi. (7) Penilaian secara autentik masih rendah. (8) Presentasi dan diskusi berjalan kurang efektif. Meminta mahasiswa agar bersedia secara sukarela mempresentasikan tugasnya agak sulit terlaksana atau tidak lancar. Pada awalnya tidak ada yang secara spontan mau mempresentasikan tugasnya. (9) Mahasiswa kurang terampil dalam mengemukakan pertanyaan/pendapat secara lisan. (10) Pada saat presentasi, partisipasi anggota kelompok dalam presentasi dan diskusi kurang baik. Ada mahasiswa yang dominan dan ada mahasiswa yang perannya sangat minimal. (11) Pada Siklus I mahasiswa dalam mempresentasikan tugasnya lebih banyak membaca apa yang sudah mereka tulis atau ditayangkan dilayar dengan media Powerpoint. Belum disertai uraian, argumentasi, penjelasan tambahan, atau penalaran. (12) Media Powerpoint yang dibuat mahasiswa masih belum baik, kurang menarik (dilihat dari desain dan layout), kurang sistematis, terlalu banyak animasi yang tidak penting, dan kurang dilengkapi gambar atau video yang dapat memperkuat pesan/informasi yang hendak disampaikan. (13) Mahasiswa masih terkesan enggan, merasa takut, kurang percaya diri dalam presentasi dan diskusi. Mahasiswa kurang lancar dan masih grogi Jurnal Pendidikan Indonesia | 96 
dalam berkomunikasi. (14) Kelompok mahasiswa kurang kerjasama dalam presentasi maupun dalam diskusi. (15) Permasalahan yang diajukan mahasiswa dalam diskusi kurang fokus atau sering keluar dari tuntutan kompetensi dasar sebagaimana tertuang dalam SAP. (16) Mahasiswa yang tidak presentasi kurang ada kesiapan dalam diskusi, sehingga kurang aktif dalam diskusi. (17) Mahasiswa dalam menyampaikan gagasan, bertanya, menjawab pertanyaan sering tidak dapat disampaikan secara jelas dan operasional. (18) Terjadinya peningkatan skor rerata antara perkembangan aktual dan perkembangan terdekat. (19) Pada siklus I, dari 12 atribut soft skills yang menjadi fokus pengembangan, terdapat 3 atribut sudah kategori baik atau sangat baik, yaitu kerjasama, menghargai orang lain, dan kejujuran. Atribut soft skills yang dinilai masih perlu dikembangkan, yaitu masih berada pada kategori cukup atau kurang, yaitu keterampilan berkomunikasi, manajemen waktu, disiplin, motif berprestasi, berpikir kritis, berargumentasi logis, antusiasme, bertanggung jawabdan kepercayaan diri. (20) Pemberian soft skills di awal perkuliahan terkadang tidak efektif, karena pesan soft skills yang diberikan terkadang tidak tepat momen atau konteksnya.

\section{Tindakan Siklus II}

Berdasarkan hasil refleksi tindakan pada siklus I, maka pada siklus II modifikasi tindakan dilakukan seperti di bawah ini. (1) Kelemahan presentasi yang kurang efektif pada siklus I karena materi pokok bahasan yang cukup luas disajikan hanya oleh satu kelompok, maka pada siklus II materi presentasi untuk satu pokok bahasan dibagi menjadi 2 bagian, dan disajikan oleh 2 kelompok secara bergiliran. Dengan demikian lebih banyak mahasiswa yang memperoleh kesempatan presentasi. (2) Powerpoint yang disiapkan mahasiswa untuk presentasi disarankan untuk melengkapi dengan gambar atau video, agar infomasi atau penjelasan menjadi lebih mudah dipahami. (3) Setiap mahasiswa diminta atau ditugaskan menyiapkan pertanyaan atau permasalahan yang akan diajukan atau didiskusikan pada saat presentasi dan diskusi. Permasalahan atau pertanyaan ini disiapkan secara tertulis untuk mengatasi kendala mengkomunikasikan gagasan oleh mahasiswa langsung secara lisan. (4) Pengembangan soft skills pada siklus I lebih banyak diberikan pada awal perkuliahan. Cara ini dinilai kurang efektif dilihat dari momennya. Pada siklus II upaya pengembangan soft skills diberikan bisa diawal, diakhir, atau di tengah-tengah jika dipandang ada momentum yang tepat untuk memberikan soft skills. Pesan atau atribut soft skills yang diberikan disesuaikan dengan situasi dan kondisinya. Cara penyampaian pesan soft skills antara lain dengan cerita, gambar, dan atau video dengan kisaran waktu \pm 5 smapai dengan 7 menit. (5) Agar diskusi dapat dikelola lebih sistematis dan terorganisir, maka pertanyaan-pertanyaan yang diajukan mahasiswa tidak langsung ditanggapi, melainkan terlebih dahulu dikoleksi (diinventarisir) oleh mahasiswa dan juga oleh dosen pengajar. Selanjutnya dosen pengajar membantu menyusun dan mengurut pertanyaan-pertanyaan yang diajukan oleh mahasiswa agar diskusi dan pembahasan menjadi lebih sistematis dan terorganisir. (6) Agar terjadi tanggung jawab bersama oleh anggota kelompok dalam presentasi, maka tugas presentasi Jurnal Pendidikan Indonesia | 97 
disarankan untuk berbagi dan begitu pula halnya dalam menanggapi pertanyaanpertanyaan oleh mahasiswa lainnya. (7) Kepada mahasiswa pada saat presentasi diminta tidak hanya membacakan tugas reviunya, tetapi juga dituntut agar mampu memberikan uraian atau penjelasan tambahan.

\section{Refleksi Siklus II}

Hasil observasi dan evaluasi setelah dilaksanakan tindakan II dapat dibuat refleksi siklus II sebagai berikut. (1) Rerata nilai partisipasi presentasi-diskusi pada siklus II adalah 3,1 dengan kategori baik. Terdapat peningkatan aktivitas presentasidiskusi yang signifikan dari cukup pada siklus I menjadi baik pada siklus II. Rerata nilai spontanitas mahasiswa dalam presentasi-diskusi 3,0 dengan kategori baik. Terdapat peningkatan spontanitas dalam presentasi-diskusi 2,5 (baik) pada siklus I menjadi 3,0 (baik) pada siklus II. Aktivitas belajar mahasiswa dilihat dari antusiasme dalam presentasi-diskusi adalah baik. Terjadi kenaikan rerata nilai antusiasme cukup pada siklus I menjadi baik pada siklus II. (2) Nilai tugas membuat reviu pokok bahasan pada Siklus II adalah sangat baik. Terdapat kenaikan rerata skor membuat tugas reviu pokok bahasan dibandingkan pada siklus I, yaitu dari baik menjadi sangat baik. (3) Nilai perkembangan aktual mahasiswa pada siklus II adalah kurang. Nilai perkembangan aktual lebih baik daripada siklus I, yaitu dari 37,2 (sangat kurang) menjadi 46,7 (kurang). (4) Nilai perkembangan terdekat pada siklus II kategori baik. Terjadi sedikit peningkatan dibandingkan pada siklus I 79,2 (baik) menjadi 80,8 (baik) pada siklus II. (5) Nilai tes akhir pada siklus II adalah 82,1 dengan kategori baik. Terjadi peningkatan nilai tes akhir yang signifikan dibandingkan pada siklus I. Pada siklus I rerata nilai tes akhir 66,1 (cukup) menjadi rerata 82,1 (baik) pada siklus II. (6) Kepemilikan atribut soft skills oleh mahasiswa juga mengalami peningkatan. Rerata skor kepemilikan atribut soft skills pada siklus I cukup meningkat menjadi baik pada siklus II. (7) Upaya perbaikan tindakan pada siklus II, seperti membagi materi presentasi menjadi dua bagian memberikan peluang presentasi kepada lebih banyak mahasiswa ternyata mampu menjadikan presentasi lebih lancar dan aktivitas belajar juga meningkat. Demikian pula halnya dengan pemberian materi soft skills yang disesuaikan dengan momen (relevan dengan situasi dan kondisi) lebih mengena atau lebih bermakna bagi mahasiswa. Keseluruhan perbaikan tindakan pada siklus II terbukti telah mampu meningkatkan hasil belajar mahasiswa.

\section{HASIL PENELITIAN}

Aktivitas belajar mahasiswa diukur dengan menggunakan parameter 1) partisipasi dalam presentasi-diskusi, 2) spontanitas dalam presentasi-diskusi, dan 3) antusiasme dalam mengikuti pembelajaran. Dari data penelitian diperoleh bahwa ketiga parameter tersebut menunjukan adanya peningkatan dari siklus I ke siklus II. Untuk parameter partisipasi dalam presentasidiskusi, naik dari 2,2 (cukup) menjadi 3,1 (baik). Untuk parameter spontanitas dalam presentasi-diskusi, naik dari 2,5 (baik) menjadi 3,0 (baik). Sedangkan untuk parameter antusiasme dalam mengikuti pembelajaran, terjadi kenaikan dari 2,0 (cukup), dan 3,0 (baik).

Aktivitas belajar mahasiswa juga diukur dari performance (kinerja) mahasiswa selama pembelajaran berlangsung. Pengukuran secara autentik (autentik Jurnal Pendidikan Indonesia | 98 
asesmen) menunjukkan bahwa kinerja mahasiswa mengalami peningkatan dari siklus I dan II. Kinerja mahasiswa tersebut dilihat dari jumlah mahasiswa berpartisipasi, frekuensi partisipasi, dan kualitas (skor) partisipasi mahasiswa. Untuk parameter kinerja mahasiswa dalam pembelajaran, terjadi kenaikan dalam hal jumlah mahasiswa berpartisipasi secara aktif dari 15 orang menjadi 21 orang, frekuensi partisipasi dari 20 menjadi 32, dan skor kinerja dari 37 menjadi 67.

Hasil belajar mahasiswa yang diukur dengan menggunakan parameter 1) nilai tugas membuat reviu pokok bahasan, 2) nilai perkembangan aktual, 3) nilai perkembangan terdekat, dan 4) hasil tes pada akhir siklus. Dari data penelitian diperoleh bahwa keempat parameter tersebut menunjukan adanya peningkatan dari siklus I ke siklus II. Untuk parameter tugas membuat reviu pokok bahasan, skor naik dari 84,2 (baik) menjadi 86,7 (sangat baik). Untuk nilai perkembangan aktual, skor naik dari 37,2 (sangat kurang) menjadi 46,7 (kurang). Untuk nilai perkembangan terdekat, skor naik dari 79,2 (baik) menjadi 80,8 (baik). Untuk nilai tes akhir siklus, skor naik dari 66,1 (cukup) menjadi 82,1 (baik).

Pada penelitian ini pengukuran atribut soft skills difokuskan pada 12 atribut soft skills yang dominan dapat dikembangkan. Pengukuran atribut soft skills dalam penelitian ini dinilai melalui pengisian angket masing-masing oleh diri sendiri (self evaluation), teman dalam kelompok, dan oleh dosen pengajar. Dari hasil pengukuran diperoleh terjadi peningkatan kepemilikan atribut soft skills dikalangan mahasiswa. Rerata skor soft skills mahasiswa pada siklus I adalah 3,4 (cukup) naik menjadi 3,7 (baik) pada siklus II.

\section{PEMBAHASAN}

Upaya pengembangan soft skills mahasiswa melalui model pembelajaran kooperatif pada pembelajaran Kimia Dasar dapat meningkatkan aktivitas belajar mahasiswa. Mahasiswa menjadi lebih aktif berpartisipasi dalam diskusi, lebih berani mengemukakan pendapat, dan lebih bersemangat (antusias). Upaya pengembangan soft skills berhasil meningkatkan kepemilikan atribut soft skills yang berpengaruh terhadap terjadinya peningkatan aktivitas belajar mahasiswa. Model pembelajaran kooperatif yang diterapkan juga mendorong aktivitas belajar mahasiswa menjadi lebih baik atau meningkat berkat diskusi, kerjasama, dan sharing yang terjadi dalam kelompok.

Dari hasil penelitian diperoleh bahwa kemampuan mahasiswa membuat tugas reviu pokok bahasan adalah baik. Data rerata nilai tugas membuat reviu yang baik adalah indikasi dari persiapan belajar mahasiswa yang baik, berkat peningkatan kepemilikan soft skills mahasiswa yang pada akhirnya berpengaruh terhadap semangat bekerja secara kooperatif.

Nilai perkembangan aktual mahasiswa dari siklus I dan II menunjukkan kecenderungan meningkat. Namun kenaikan hanya terjadi dari 37,2 (sangat kurang) pada siklus I menjadi 46,7 (kurang) pada siklus II. Dilihat dari parameter ini menunjukkan bahwa penguasaan mahasiswa terhadap bahan kuliah sebagai produk belajar individu ada pada kategori sangat kurang atau kurang. Aspek ini yang hendak ditingkatkan melalui model pembelajaran kooperatif.

Nilai perkembangan terdekat yang menunjukkan hasil belajar mahasiswa melalui proses pembelajaran kooperatif dari siklus I ke siklus II ada pada kategori baik. 
Hal ini menunjukkan hasil pencapain yang konsisten dengan kategori baik pada setiap siklusnya. Capaian hasil belajar tersebut dikontribusi oleh model pembelajaran kooperatif dan juga meningkatnya kepemilikan atribut soft skills mahasiswa. Mahasiswa mendapat manfaat dari belajar kooperatif. Artinya, antarmahasiswa telah terjadi sharing pengetahuan, dimana dalam belajar antarmahasiswa telah terjadi proses saling melengkapi, sehingga setiap mahasiswa mendapat manfaat berupa penguasaan materi kuliah menjadi lebih baik. Semangat untuk belajar secara kooperatif didukung oleh soft skills mahasiswa yang meningkat. Mahasiswa yang kemampuan akademisnya kurang mendapat bantuan dari mahasiswa yang memiliki penguasaan materi kuliah lebih baik. Mahasiswa yang penguasaan materi kuliah lebih baik juga mandapat hasil belajar dari kegiatannya membantu temannya yang kurang. Hal demikian itu sejalan dengan tujuan pembelajaran kooperatif, yaitu belajar belum selesai jika salah satu teman dalam kelompok belum menguasai bahan pembelajaran. (Budi Jatmiko, 2004: 7). Temuan dalam penelitian ini juga sejalan dengan konsep aspek sosial belajar menurut Vygotsky tentang zone of proximal development (zona perkembangan terdekat). Di mana pembelajaran terjadi melalui interaksi sosial dengan teman sejawat. Bantuan dari teman sejawat yang lebih mampu, siswa bergerak ke dalam zona perkembangan terdekat mereka di mana pembelajaran baru terjadi (Ibrahim dan Nur, 2000: 18-19). Malalui upaya pengembangan soft skills yang dipadukan dengan model pembelajaran kooperatif dapat menciptakan lingkungan sosial siswa (masyarakat) belajar (learning community), pembelajaran yang berpusat pada siswa (student centered), dan belajar lebih bermakna.

Penyelenggaraan tes di akhir siklus pada penelitian ini merupakan salah satu cara untuk mengukur hasil belajar mahasiswa. Rerata nilai hasil tes menunjukkan peningkatan secara signifikan dari siklus I ke siklus II. Nilai tes ini menunjukkan hasil belajar mahasiswa setelah tindakan upaya pengembangan soft skills mahasiswa melalui pembelajaran kooperatif. Nilai tes ini juga merupakan hasil belajar (perkembangan terdekat) mahasiswa setelah berinteraksi dengan teman sejawat dan dosen.

Tindakan piningkatan kepemilikan atribut soft skills di kalangan mahasiswa dapat dilakukan melalui cerita, penayangan gambar, dan pemutaran video yang inspiratif atau berisi muatan soft skills. Tindakan pemberian selingan materi soft skills lebih bermakna jika diberikan tepat pada momentumnya. Artinya, tepat waktu (bisa di awal kuliah, disisipkan saat perkuliahan, atau pada akhir perkuliahan), dan materi soft skills relevan dengan situasi dan kondisi saat itu. Respon mahasiswa terhadap upaya pengembangan soft skills melalui implementasi model pembelajaran kooperatif pada pembelajaran Kimia Dasar secara umum adalah positif dan berharap model pembelajaran ini dapat diterapkan pada mata kuliah lainnya.

\section{SIMPULAN DAN SARAN}

Berdasarkan hasil penelitian ini dapat dibuat simpulan sebagai berikut.

Upaya pengembangan soft skills melalui implementasi model pembelajaran kooperatif pada pembelajaran Kimia Dasar dapat (1) meningkatkan soft skills mahasiswa, (2) meningkatkan aktivitas belajar mahasiswa, (3) meningkatkan hasil 
belajar mahasiswa, dan (3) mahasiswa memberikan respon positif terhadap upaya pengembangan soft skills yang diimplementasikan melalui model pembelajaran kooperatif.

Implikasi dari penelitian ini adalah bahwa upaya pengembangan soft skills melalui implementasi model pembelajaran kooperatif layak untuk dicoba diterapkan pada mata kuliah lainnya. Agar penerapan model pembelajaran ini dapat memberikan hasil yang lebih optimal disarankan agar atribut soft skills yang menjadi pengembangan dapat diperluas dan perlu dikembangkan instrumen untuk pengukuran atribut soft skills.

\section{DAFTAR PUSTAKA}

Budi Djatmiko. 2004. Model-model Pembelajaran (DI, Kooperatif, dan $P B$ ). Makalah UNESA

Darmiyati Zuchdi, Zuhdan Kun Prasetya, dan Muhsinatun Siasah Masruri. 2010. Pengembangan Model Pendidikan Karakter Terintegrasi dalam Pembelajaran Bidang Studi di Sekolah Dasar. Jurnal Cakrawala Pendidikan, Mei 2010, Th. XXIX, Edisi Khusus Dies Natalis UNY. Halaman $1-12$

Elfindri, Jemmy Rumengan,. Muhammad Basri Wello, Poltak Tobing, Fitri Yanti, Zein, Elfa Eriyanti, dan Ristapawa Indra. 2010. Soft skills untuk Pendidik. Baduose Media.

Hilda Karli dan Margaretha Yuliariatiningsih. 2002. Implementasi Kurikulum Berbasis Kompetensi. Model-model Pembelajaran 2. Cetakan Pertama. Edisi Kesatu. Bandung: Bina Media Informasi.

Illah Sailah. 2007. "Pengembangan Soft skills di Perguruan Tinggi. Makalah disampaikan dalam rangka Sosialisasi Pengembangan Soft skills di Undiksha, tanggal 26 April 2007.
Ibrahim, Muslimin; Nur, Mohamad. 2004. Pengajaran Berdasarkan Masalah. Cetakan Kedua. Surabaya: UNESA University Press.

Slavin, Robert E. 1995. Cooperative Learning: Theory, Research, and Practice. Second Edition. USA: Allyn \& Bacon.

Simon Attle dan Bob Baker. 2007. Cooperative Learning in a Competitive Environment: Classroom Applications. International Journal of Teaching and Learning in Higher Education 2007, Volume 19, Number 1, $77-83$.

Sriartha, I Putu dan Sudiana, I Ketut. 2009. Buku Panduan Pengembangan Soft skills Mahasiswa Undiksha melalui Multilevel Role Model Berlandaskan Trikaya Parisudha. Universitas Pendidikan Ganesha. Singaraja

Suryanti. 1998. Pengembangan Model Pembelajaran Tipe Teams Game Turnamen (TGT) dalam Meningkatkan Hasil Belajar Fisika SMU. Tesis (tidak diterbitkan) IKIP Singaraja.

Te - Yi Chan, Rou - Mei Wang, Bin - Shyan Jong, Yen - The Hsia and Tsong Wuu Lin. 2008. Conceptual Graph Based Learning Material. Producing Strategy For Cooperative Learning. ASEE/IEEE Frontiers in Education Conference. $38^{\text {th }}$. $978-1-4244-$ 1970 - 8/08. October $22-25,2008$, Saratoga Springs, New York.

Triatmanto. 2010. Tantangan Implementasi Pendidikan Karakter di Sekolah. Jurnal Cakrawala Pendidikan, Mei 2010, Th. XXIX, Edisi Khusus Dies Natalis UNY. Halaman $187-203$ 



\title{
PENGEMBANGAN BAHAN AJAR \\ METODE PEMBELAJARAN BAHASA DAN SASTRA INDONESIA \\ BERBASIS PEMBELAJARAN KOOPERATIF JIGSAW \\ UNTUK MENINGKATKAN PEMAHAMAN \\ DAN KEMAMPUAN APLIKATIF MAHASISWA
}

\author{
Gede Nurjaya \\ Jurusan Pendidikan Bahasa dan Sastra, Fakultas Bahasa dan Seni, \\ Universitas Pendidikan Ganesha, Singaraja, Indonesia
}

\begin{abstract}
Abstrak
Tujuan utama penelitian ini adalah menghasilkan bahan ajar Metode Pembelajaran Bahasa dan Sastra Indonesia yang mampu meningkatkan pemahaman dan kemampuan aplikatif mahasiswa. Untuk tujuan itu, rancangan penelitian yang digunakan adalah rancangan penelitian dan pengembangan (R\&D). Penelitian ini membutuhkan waktu dua tahun untuk menghasilkan produk yang siap pakai.

Pada tahun kedua ini adalah uji coba efektivitas penggunaan bahan ajar. Hasilnya adalah sebagai berikut ini. (1) Prestasi mahasiswa setelah diajarkan dengan menggunakan bahan ajar yang telah disusun berada pada kategori baik dengan rata-rata skor 79,42. Skor untuk pemahaman sebesar 81,17 dalam kategori baik, lebih tinggi dibandingkan skor kemampuan aplikatif yang sebesar 76,8 pada kategori baik juga. (2) Respon mahasiswa terhadap penggunaan bahan ajar dalam pembelajaran adalah positif dengan rata-rata 4,43 pada skala 5. (3) Kendalaa yang dihadapi oleh mahasiswa saat penggunaan bahan ajar tersebut dalam pembelajaran adalah kekurang waktu dan ada beberapa bagian bahan ajar yang sulit dipahami karena redaksinya.
\end{abstract}

Kata kunci: bahan ajar, prestasi, respon, kendala

\begin{abstract}
The study aimed at producing learning materials for the course of "Method of Indonesian language and arts" in order to be able to increase the students' comprehension and application. The research design used was resarch and development model (R\&D). The study needed some steps before producing a ready-to-use product.

In the second year of the reserach project, the study conducted an experiment to measure the efficacy of the product. The results of the experiment was as follows: a) Students achievement after being taught using the designed learning materials falls within the good category with $M=79.42$. The means of comprehension score is 81.17 which is categorised good. It is higher than the score of application which is 76.8 ; b) students response is very positif towards the use of designed learning materials as shown by means of score which is 4.43 at scale 5 . c) the only constraint faced by students in using the designed learning materials is the time allotment. Besides, some parts of the materials are difficult to understand, especially, their sentences.
\end{abstract}

Keywords: learning materials, achievement, response, constraint 


\section{PENDAHULUAN}

Mata kuliah Metode Pengajaran Bahasa dan Sastra Indonesia (MPBSI) adalah salah satu mata kuliah yang diharapkan dapat membentuk mahasiswa menjadi seorang guru Bahasa dan Sastra Indonesia. Dengan demikian, mata kuliah ini seharusnya membekali peserta didik berbagai konsep dan keterampilan mengajar yang dibutuhkan untuk menjadi seorang guru Bahasa dan Sastra Indonesia. Selain itu, mata kuliah ini seharusnyalah menjadi mata kuliah yang bersifat aplikatif bukan sekadar teoretis belaka. Hanya saja, untuk menjadikan mata kuliah ini sebagai bidang yang aplikatif tampaknya masih merupakan kendala yang perlu dipecahkan.

Dari pengalaman membimbing mahasiswa yang mengambil mata kuliah pengajaran mikro dan pada saat mereka praktik mengajar di sekolah, kentara sekali bahwa mahasiswa lebih banyak mengetahui hal inwal metode pengajaran bahasa secara verbalistis (teoretis). Pengetahuan mereka itupun kurang disertai pemahaman yang bersifat analitis apalagi praktis. Keadaan yang demikian ini menyebabkan mereka, umumnya, kurang memiliki keterampilan untuk mengaplikasikan konsep-konsep Metode Pengajaran Bahasa dan Sastra Indonesia dalam pembelajaran ketika mereka praktik mengajar. Pemahaman konsep mereka pun ternyata kurang memadai juga.

Keadaan demikian itu, tampaknya disebabkan oleh pembelajaran mata kuliah tersebut yang kurang memberikan kesempatan bagi para mahasiswa untuk, selain mampu memahami konsep metodelogi. juga mampu mengaplikasikannya dalam kegiatan pembelajaran.
Untuk menanggulangi permasalahan seperti itu, telah ditemukan model pembelajaran yang efektif yaitu pembelajaran kooperatif tipe jigsaw. Model ini ternyata mampu meningkatkan pemahaman teoretis dan kemampuan aplikatif mahasiswa dalam mata kuliah tersebut. Hal ini dimungkinkan karena model ini memberikan kesempatan kepada mahasiswa untuk memahami konsep metode PBSI tersebut secara berkelompok. Pemahaman secara berkelompok diharapkan mampu menjadi solusi pemecahan permasalahan yang muncul ketika mereka mempelajari konsep metode tersebut secara mandiri. Apalagi pada saat pemahaman konsep secara kelompok ini, mereka dibimbing oleh dosen pembimbingnya. Setelah terjadi pemahaman konsep, secara individu, mereka harus bertanggung jawab terhadap pemahamannya karena mereka akan menyampaikan pemahamannya kepada teman lain pada kelompok lain. Kegiatan menyajikan pemahaman kelompok oleh individu kepada teman dari kelompok lain ini mengharuskan mereka untuk memiliki pemahaman yang betul-betul baik agar kelompok lain juga memiliki pemahaman yang sama dengan yang dimiliki oleh kelompoknya sendiri.

Selain pemahaman yang baik terhadap konsep yang menjadi tugasnya, mahasiswa secara individu juga harus mempersiapkan teknik penyajian yang baik sehingga memudahkan teman dari kelompok lain memahami konsep yang disajikan. Pada tahap menyajikan konsep pada kelompok lain inilah berbagai startegi harus diterapkan dan berbagai perlengkapan untuk mengajar harus disiapkan. Tahap ini menjadi kunci 
penguasaan keterampilan mengaplikasikan berbagai konsep yang telah dikuasai.

Agar model pembelajaran dapat terlaksana dengan baik maka diperlukan perangkat pembelajaran lainnya seperti bahan ajar dan evaluasi yang relevan dengan model yang digunakan. Dengan pertimbangan bahwa model pembelajaran tidak dapat berdiri sendiri, tanpa perangkat pendukungnya, maka dilakukanlah penelitian pengembangan bahan ajar untuk mata kuliah Metode Pembelajaran Bahasa dan Sastra Indonesia.

Penelitian pengembangan bahan ajar Metode PBSI ini ditujukan untuk menghasilkan bahan ajar untuk mata kuliah Metode Pembelajaran Bahasa dan Sastra Indonesia yang berkualitas dengan berbasiskan pembelajaran kooperatif jigsaw untuk dapat meningkatkan pemahaman dan kemampuan aplikatif mahasiswa.

Untuk mencapai tujuan utama tersebut diperlukan tujuan khusus yang memerlukan dua tahap penelitian. Untuk tahun pertama, tujuan khusus ini adalah untuk menetapkan dan mendifinisikan syarat-syarat bahan ajar yang sesuai dengan kebutuhan kurikulum dan kebutuhan mahasiswa, menemukan prototype bahan ajar yang dibutuhkan, dan menetapkan tingkat validitas bahan ajar melalui validasi. Tujuan tahun kedua adalah untuk mengetahui tingkat efektifitas bahan ajar yang disusun terhadap peningkatkan pemahaman dan kemampuan aplikatif mahasiswa pada mata kuliah Metode Pembelajaran Bahasa dan Sastra Indonesia. Kegiatan tahun kedua ini merupakan tahap uji coba penggunaan bahan ajar untuk mengetahui prestasi dan respon mahasiswa, serta kendala yang dihadapi jika pembelajaran menggunakan bahan ajar yang disusun.
Bahan ajar yang telah tersusun memiliki peranan penting dalam pembelajaran. Dalam pandangan tradisional seperti dikemukakan oleh macomber (1952), bahan ajar merupakan "subject matter". Bahan ajar yang saat itu sering disebut materi pelajaran dikatakan sebagai suatu kebulatan pengetahuan yang tersusun secara sistematis dari satuan-satuan materi pelajaran. Pandangan modern justru menganggap materi pelajaran bukanlah tujuan. Bahan ajar adalah alat dan media yang memberi peluang kepada siswa untuk memperoleh pengalaman belajar. Dengan dan melalui bahan ajar yang tersedia, pembelajar akan memperoleh pengalaman berhubungan dengan a) fakta-fakta dalam kehidupan, b) model-model kehidupan, c) simbol-simbol yang dipakai dalam kehidupan (Sriasih, 2008). Melalui pengalaman ini pembelajar akan berlatih 1) menilai dan mengembangkan ide-ide, 2) memecahkan persoalan, 3) memperoleh keterampilan, dan 4) membina dan mengembangkan sikap mental serta daya apresiatif dan kreatif.

Bahan ajar yang tersusun dalam bentuk modul biasanya memberi peluang yang lebih banyak kepada mahasiswa untuk mencapai harapan di atas. Modul sendiri menurut Russel (1974:3) adalah "...an instructional package dealing with a single conseptual unit of subject matter", sedangkan Warwich (1996) mendefinisikan modul sebagai suatu unit kurikulum yang lengkap, dan dapat ditambah dengan pencapaian tugas yang lebih besar atau tujuan-tujuan jangka panjang. Modul sebagai bahan pembelajaran memiliki struktur yang khas terdiri dari pendahuluan yang berisi uraian singkat tentang cakupan materi modul, tujuan pembelajaran, dan urutan bahasan (kegiatan belajar). Pada Jurnal Pendidikan Indonesia | 104 
kegiatan belajar berisi sajian materi, contoh, latihan serta rangkuman yang bersifat interaktif untuk menumbuhkan pembelajaran (Winataputra, dkk, 1972:2). Modul diharapkan disusun sedemikian rupa agar memungkinkan 1) meningkatkan secara maksimal kegiatan pembelajaran, 2) terselenggaranya proses maju berkelanjutan secara efektif, 3) pembelajaran berpusat pada siswa (Depdikbud, 1985:4). Modul yang disusun dengan baik dapat memberikan banyak keuntungan, yaitu 1) dapat meningkatkan secara maksimal pembelajaran, 2) pembelajar lebih aktif dalam proses belajarnya karena menghadapi sejumlah masalah atau tugas yang harus dikerjakan, 3) dapat memberikan balikan dengan segera sehingga pembelajar dapat mengetahui hasil belajarnya, 4) kegiatan pembelajar terarah karena modul mengandung sasaran belajar yang jelas, dan 5) keterlibatan pengajar dalam pembelajaran sangat minimal (Russel, 1974:20; Suryobroto, 1983:16; dan Nasution, 2000:206).

\section{METODE PENELITIAN}

Penelitian ini menggunakan rancangan penelitian dan pengembangan dengan tahapan yang sering dikenal dengan 4-D (define, design, develop, disseminate). Pengembangan materi pembelajaran ini mengacu pada model pengembangan Dick \& Carey (1990).

Kegiatan penelitian ini terdiri dari: (1) melakukan analisis kebutuhan (need assesment), (2) menetapkan pokok-pokok materi yang akan dikembangkan, dan (3) mengembangkan prototype, (4) validasi ahli, (5) uji coba.

Pada tahun kedua dari pengembangan bahan ajar Metode PBSI ini dilakukan tahapan uji coba untuk mengetahui prestasi dan respon mahasiswa terhadap penggunaan bahan ajar yang tersusun. Selain itu, juga untuk mengetahui kendala yang dihadapi. Sehubungan dengan itu, data penelitian ini dikumpulkan dengan metode tes dan angket. Metode tes meliputi tes pemahaman dan tes unjuk kerja untuk menjaring kemampuan aplikatif. Angket dipakai untuk menjaring data respon dan kendala yang dihadapi. Untuk respon, digunakan angket terstruktur dan untuk kendala digunakan angket terbuka.

\section{HASIL DAN PEMBAHASAN \\ Hasil Prestasi mahasiswa}

Pelaksanaan uji coba penggunaan bahan ajar Metode PBSI dalam pembelajaran dilaksanakan pada semester genap tahun ajaran 2010/2011. Uji coba ini melibatkan tiga kelas yang ada di Jurusan Pendidikan Bahasa dan Sastra Indonesia dengan jumlah mahasiswa yang terlibat ketika uji coba sebanyak 60 orang dengan rincian sebagai berikut: kelas A sebanyak 28 orang, kelas $B$ sebanyak 18 orang, dan kelas C sebanyak 14 orang. Uji coba dilaksanakan sebanyak dua kali dengan materi yang diajarkan adalah pendekatan komunikatif dan model pembelajaran konstruktivisme.

Setelah dilakukan tes sehabis pelaksanaan pembelajaran dengan menggunakan bahan ajar "Metode PBSI" yang disusun ditemukan prestasi mahasiswa berada pada kategori baik dengan rata-rata 79,42 . Jika dilihat secara parsial masingmasing kemampuan, yaitu kemampuan pemahaman konsep dan kemampuan aplikatif, tampak ada perbedaan, walupun masih berada pada kategori baik. Rata-rata kemampuan pemahaman mahasiswa adalah 81,17 , sedangkan rata-rata kemampuan aplikatif adalah 76,8. 
Kemampuan pemahaman ternyata lebih tinggi dari kemampuan aplikatif dengan selisih 4,37 poin. Ini menunjukkan bahwa mahasiswa lebih mampu memahami konsep dibandingkan dengan mengaplikasikan konsep yang dipahaminya.
Jika dilihat perimbangan antara kategori prestasi mahasiswa, tampaknya sebagian besar mahasiswa tergolong ke dalam kategori sangat baik, seperti tampak pada tabel berikut.

Tabel 1: Perimbangan jumlah dan persentase kategori prestasi mahasiswa

\begin{tabular}{|l|l|l|l|}
\hline No & Kateori & Jumlah & Persentase \\
\hline 1. & Sangat baik & 27 & 45 \\
\hline 2. & Baik & 21 & 35 \\
\hline 3. & Cukup & 12 & 20 \\
\hline 4. & Kurang & - & - \\
\hline 5. & Sangat kurang & - & - \\
\hline \multicolumn{2}{|c|}{ Jumlah } & 60 & 100 \\
\hline
\end{tabular}

Tabel di atas memperlihatkan perimbangan tingkat prestasi mahasiswa berdasarkan kategorinya. Dari tabel tersebut terlihat bahwa kategori prestasi mahasiswa berada pada tiga kategori yaitu sangat baik, baik, dan cukup. Tidak ada mahasiswa yang berada pada kategori kurang dan sangat kurang. Kategori sangat baik bahkan menduduki peringkat teratas dengan jumlah $45 \%$. Kategori cukup malahan berada pada peringkat paling rendah dengan jumlah $20 \%$ masih di bawah kategori baik yang sebesar $35 \%$.

\section{Hasil Respon Mahasiswa}

Utuk menjaring respon mahasiswa terhadap efektivitas penggunaan bahan ajar Metode PBSI dalam pembelajaran, digunakan delapan pernyataan. Kedelapan pernyataan tersebut adalah (1) Saya senang dengan pembelajaran dengan cara seperti yang diterapkan dosen, (2) Saya senang dosen memberikan bahan ajar untuk didiskusikan, (3) Saya tertarik dengan model penataan bahan ajar yang diberikan, (4) Saya dapat memahami bahan ajar yang diberikan guru, (5) Bahan ajar memudahkan saya dalam memahami materi pelajaran, (6) Saya bisa mengaplikasikan konsep yang ada pada bahan ajar untuk menyusun skenario pembelajaran, (7) Saya bisa membuat skenario pembelajaran dengan mengkaji bahan ajar yang diberikan dosen secara berkelompok, dan (8) Saya ingin dosen tetap memberikan bahan ajar dalam setiap pembelajaran. Hasil angket berupa respon mahasiswa terhadap penggunaan bahan ajar Metode PBSI dalam pembelajaran, dapat dilihat pada tabel berikut. 
Tabel 2: Hasil angket respon mahasiswa terhadap penggunaan bahan ajar metode PBSI dalam pembelajaran

\begin{tabular}{|c|c|c|c|c|c|c|c|}
\hline \multirow{2}{*}{$\begin{array}{c}\text { No. } \\
\text { Pernyataan }\end{array}$} & \multicolumn{5}{|c|}{ Pilihan Jawaban } & \multirow[b]{2}{*}{ Rerata } & \multirow[b]{2}{*}{ Kategori } \\
\hline & $\begin{array}{l}\text { SS } \\
\text { (5) }\end{array}$ & $\begin{array}{c}S \\
\text { (4) }\end{array}$ & KS (3) & $\begin{array}{l}\text { TS } \\
\text { (2) }\end{array}$ & $\begin{array}{c}\text { STS } \\
\text { (1) }\end{array}$ & & \\
\hline 1. & 45 & 15 & - & - & - & 4,75 & Sangat positif \\
\hline 2. & 35 & 25 & - & - & - & 4,58 & Sangat positif \\
\hline 3. & 25 & 35 & - & - & - & 4,42 & positif \\
\hline 4. & 5 & 55 & - & - & - & 4,01 & positif \\
\hline 5. & 20 & 40 & - & - & - & 4,33 & Positif \\
\hline 6. & 20 & 40 & - & - & - & 4,33 & positif \\
\hline 7. & 20 & 40 & - & - & - & 4,33 & Positif \\
\hline 8. & 45 & 15 & - & - & - & 4,75 & Sangat positif \\
\hline Jumlah rata & +3 & +6 & & & & 4,43 & Positif \\
\hline
\end{tabular}

Berdasakan tabel hasil angket di atas, terlihat bahwa mahasiswa merespon positif penggunaan bahan ajar Metode PBSI dalam pelaksanaan pembelajaran dengan rata-rata respon adalah 4,43 dalam kategori positif. Dari delapan item pernyataan pada angket, semua pernyataan dijawab positif oleh mahasiswa. Hal ini lebih memperkuat ratarata semua item yang sebasar 4,43 tersebut.

\section{Kendala yang Dihadapi dalam Pembelajaran}

Dari angket bebas yang diisi oleh mahasiswa mengenai kendala dalam pelaksanaan pembelajaran ditemukan adanya dua kendala dalam pemanfaat bahan ajar Metode PBSI. Kedua kendala tersebut adalah (1) waktu yang terbatas dan (2) ada beberapa bagian materi yang sulit dipahami (berupa kutipan asli). Semua mahasiswa menyatakan kendala waktu sebagai kendala utama. Mengenai kendala kedua, hanya ditemukan sebanyak 50\%. Artinya hanya $50 \%$ mahasiswa sampel yang menyatakan ada beberapa bagian dari bahan ajar yang sulit dipahami. Setelah ditelusuri, ternyata kesulitan terletak pada kutipan asli yang tidak diadaptasi sesuai konteks wacana pada bahan ajar tersebut dan juga kesesuaian dengan pola bahasa atau ragam bahasa yang dikendaki oleh mahasiswa.

\section{PEMBAHASAN}

Dari temuan yang telah dikemukakan di depan, maka ada beberapa temuan menarik yang perlu dibahas lebih lanjut. Pembahasan ini meliputi prestasi mahasiswa, respon, dan kendala yang dihadapi ketika pelaksanaan pembelajaran dengan menggunakan bahan ajar yang telah disusun.

Prestasi mahasiswa yang rata-rata umumnya adalah 79,42 dengan kategori baik, tampaknya merupakan sinya bahwa pembelajaran dengan menggunakan bahan ajar yang telah disusun tampaknya mempunyai pengaruh yang cukup signifikan. Apalagi rata-rata umum ini adalah gabungan nilai pemahaman dan aplikatif yang untuk pertama kalinya dilakukan penilaian secara berimbang. Maksud berimbang di sini 
adalah penilaian aplikatif yang selama ini jarang dilakukan dalam perkuliahan mata kuliah Metode Pembelajaran, umumnya, dan khususnya Metode PBSI, sekarang ini dilakukan secara lebih seksama yang menjadi bagian yang setara dengan pemahaman konsep.

Pemberian bahan ajar yang tercetak kepada mahasiswa tampaknya juga ikut berkontribusi terhadap prestasi mereka mengikuti perkuliahan. Logikanya adalah dengan diberikan bahan ajar yang tercetak, maka waktu yang biasanya tersita untuk mencatat materi dapat dikurangi dan konsentrasi mahasiswa untuk bekerja dalam pembelajaran dapat ditingkatkan. Hal ini tampaknya disebabkan oleh komponen bahan ajar seperti kompetensi dasar dan indikator yang secara eksplisit dapat mereka baca dari bahan ajar ini. Sesuai dengan konsep pembalajaran seperti dikemukakan dalam konsep pembelajaran mikro, bahwa pemahaman dan konsentrasi mahasiswa dapat ditingkatkan jika mereka mengetahui dari awal tujuan pemnbelajarannya dan langkah-langkah kegiatan yang dapat dilakukan selama pembelajaran.

Hal menarik yang berkaitan dengan prestasi yang juga perlu dicermati adalah adanya perbedaan kemampuan pemahaman dan kemampuan aplikatif. Kemampuan pemahaman lebih tinggi perolehan hasilnya yaitu sebesar 81,17, sedangkan kemampuan aplikatif sebesar 76,8 . Ada selisih 4,37 poin dari kedua kemampuan tersebut. Hal ini dapat dijelaskan bahwa kemampuan aplikatif memang merupakan tingkatan yang lebih tinggi jika melihat taksonomi Bloom. Karena tingkatannya lebih tinggi yaitu tergolong C3 sedang pemahaman C2, maka wajarlah kemampuan aplikatif lebih sulit sehingga prestasinya lebih rendah dibandingkan pemahaman. Akan aneh, jika nilai pemahaman lebih rendah dibandingkan aplikatif. Walaupun demikian, prestasi ini masih dapat ditingkatkan jika kendala yang dihadapi selama pembelajaran dapat dihilangkan.

Ada dua kendala yang dikemukakan oleh mahasiswa dalam penerapan bahan ajar ini. Kendala pertama adalah kurangnya waktu pembelajaran. Kendala kedua adalah ada beberapa bagian materi yang sulit dipahami oleh mahasiswa. dalam hal kendala waktu, mahasiswa menganggap waktu yang tersedia untuk mengerjakan tugas perkuliahan yang menyangkut pemahaman dan kemampuan aplikatif masih terlalu singkat. Hal ini juga peneliti rasakan. Kekurangan waktu ini terjadi bisa karena beberapa kemungkinan. Jika dilihat dari konsep pembelajaran, mahasiswa atau siswa yang tidak ingat dengan berjalannya waktu selama pembelajaran adalah mahasiswa atau siswa yang asyik mengerjakan tugas-tugas pembelajaran. Kemungkinan yang lain adalah tugas yang terlalu banyak sehingga terasa waktu tersedia sedikit atau memang waktunya sedikit. Kedua kemungkinan ini tampaknya ada pada penelitian ini. Mahasiswa memang tampak asyik bekerja sehingga mereka lupa waktu. Di lain pihak, waktu perkuliahan untuk mata kuliah Metode PBSI memang kurang karena terjadi perubahan berupa pengurangan jumlah JS dari 4 JS untuk 2 SKS menjadi 2 JS untuk 2 SKS. Peneliti mengamati waktu pembelajaran yang hanya 2 JS tampaknya tidak mencukupi untuk pencapaian tingkat pemahaman dan kemampuan aplikatif dalam perkuliahan Metode PBSI.

Walaupun ada kendala seperti di atas, mahasiswa merespon positif $(4,43)$ penggunaan bahan ajar yang disusun untuk Jurnal Pendidikan Indonesia | 108 
digunakan dalam pembelajaran. Dari delapan item yang diajukan yang diajukan tidak ada yang direspon tidak positif. Mahasiswa merespon sangat positif dosennya mengajar dengan model pembelajaran yang menggunakan bahan ajar, bahkan mereka sangat menginginkan dosen terus mengajar dengan memberikan bahan ajar seperti pada saat penelitian. Selain itu, bahan ajar yang diberikan memudahkan mereka mempelajari materi sehingga dengan bahan ajar itu mereka merasa mampu membuuat skenario pembelajaran yang inovatif. Yang paling kecil responnya adalah tingkat keterbacaan bahan ajar yang memudahkan mereka memahami materi. Tampak ini menjadi salah satu kendala juga dalam pembelajaran dengan bahan ajar ini. Mahasiswa menyatakan ada beberapa bagian materi yang sulit dipahami. Setelah ditelusuri, ternyata bagian yang sulit itu adalah bagian-bagian yang kebanyakan berupa kutipan langsung dari buku lain. Kesulitan memahami kutipan langsung ini tampaknya disebabkan oleh gaya tulisan atau ragam bahasa yang digunakan oleh penulis. Ragam tulisan tersebut untuk ukuran mahasiswa sampel masih sulit dicerna. Kendala ini dipecahkan dengan jalan mengurangi kutipan langsung agar gaya atau ragam bahasanya linier dengan gaya atau ragam bahasa pada bagianbagian lainya dari bahan ajar ini.

\section{SIMPULAN DAN SARAN Simpulan}

Bersadarkan hasil analisis data dan pembahasan terhadap hasil penelitian, maka dapat disimpulkan sebagai berikut.

1. Prestasi mahasiswa setelah diajarkan dengan menggunakan bahan ajar "Metode Pembelajaran Bahasa dan
Sastra Indonesia" yang telah disusun berada pada kategori baik dengan ratarata nilai 79,42 untuk gabungan kedua kemampuan (kemampuan pemahaman dan kemampuan aplikatif). Secara sendiri-sendiri, terlihat ada perbedaan kemampuan pemahaman (rata-rata $81,17)$ dengan kemampuan aplikatif (rata-rata 76,8). Perbedaan hasil ini menunjukkan bahwa mahasiswa lebih sulit mengaplikasikan konsep dibandingkan dengan sekadar memahami konsep.

2. Respon mahasiswa terhadap penggunaan bahan ajar "Metode Pembelajaran Bahasa dan Sastra Indonesia" yang telah disusun tergolong ke dalam kategori positif dengan ratarata skor 4,43. Artinya bahan ajar yang disusun dianggap cukup berkontribusi dalam usaha mahasiswa memahami dan mengaplikasikan konsep mata kuliah Metode PBSI.

3. Ada dua kendala yang dihadapi oleh mahasiswa dalam pembelajaran dengan menggunakan bahan ajar Metode PBSI yang telah disusun. Kendala tersebut adalah (1) kekurangan waktu untuk mengerjakan tugas-tugas dan (2) ada beberapa bagian materi yang sulit dipahami sehingga penjelasan maupun bimbingan dosen pengajar masih diperlukan.

4. Uji coba penggunaan bahan ajar ini dalam pembelajaran mengisyaratkan bahwa bahan ajar yang telah disusun cukup efektif sebagai sarana untuk mengajarkan mata kuliah Metode Pembelajaran Bahasa dan Sastra Indonesia. Tingkat efektivitas tersebut tampak dari prestasi yang ditunjukkan oleh mahasiswa setelah mereka diajarkan dengan bahan ajar yang Jurnal Pendidikan Indonesia | 109 
disusun. Selain itu, respon positif mahasiswa juga menunjukkan bahwa bahan ajar ini efektif sebagai sarana belajar.

\section{Saran-saran}

Berdasarkan simpulan terhadap temuan pada penelitian ini, maka beberapa saran dapat diajukan.

1. Pengembangan bahan ajar yang disusun dengan prinsip yang sistematis ternyata dapat menunjang peningkatan prestasi mahasiswa seperti pada temuan ini. Berdasarkan kenyataan itu dapat disarankan kepada pihak yang berkeinginan menyusun bahan ajar hendaknya mengikuti model pengembangan bahan ajar yang sistemetis dengan tahapan yang jelas.

2. Respon positif mahasiswa terhadap penggunaan bahan ajar dalam perkuliahan mengindikasikan bahwa sangat penting kiranya menyiapkan bahan ajar sebagai sarana perkuliahan. Bahan ajar akan menggugah mahasiswa untuk asyik bekerja karena mereka memiliki pegangan yang pasti mengenai tugasnya pada pertemuan tersebut.

3. Walaupun model pengembangan bahan ajar ini dikhususkan penggunaannya untuk Jurusan Pendididkan Bahasa dan Sastra Indonesia di Undiksha, namun kepada pihak yang memerlukan prosedur pengembangan bahan ajar tampaknya model pengembangan ini dapat memberikan inspirasi untuk dicobakan pada jenis bahan ajar lainnya yang sejalan.

\section{DAFTAR RUJUKAN}

Arends, R. I., Wenitzky, N. E., \& Tannenboum, M. D. 2001. Exploring teaching: An introduction to education. New York: McGraw-Hill Companies.

Dahar, R. W. 1989. Teori-teori belajar. Jakarta: Erlangga.

Depdikbud.1985. Pedoman Penyusunan Modul. Jakarta. Badan Pengembangan PendidikanDepdikbud.

Dick, W. \& I. Carey. 1990. The Systematic Design of Instructional. USA: Harper Collin.

Gunter, M. A., Estes, T. H., \& Schwab, J. H. 1990. Instruction: A models approach. Boston: Allyn and Bacon.

Jacobs, G.M., Lee, G.S, \& Ball, J. 1996. Learning Cooperative Learning via Cooperative Learning: A Sourcebook of Lesson Plans for Teacher Education on Cooperative Learning. Singapore: SEAMEO Regional Language Center.

Jigsaw. 2011. http://www.jigsaw.org/

Johnson, Keith \& Morrow, Keith. 1987. Communication in the Classroom: Aplications and Methods for a Communicative Approach. England: Longman Group Ltd.

Joyce, B., \& Weil, M. 1980. Model of teaching. New Jersey: Prentice-Hall, Inc.

Kessler, Carolyn. 1992. Cooperating Language Learning: A Teacher's Resource Book. Englewood Cliffs, N.J.: Prentice Hall Regents.

Lie Anita, 2005. Coopertive Learning( mempraktikkan cooperative learning di ruang-ruang kelas). Jakarta: Grasindo.

Marton, Waldemar. 1988. Methods in English Teaching: Framework and Options. New York: Prentice Hall.

Muslimin,M.pd,dkk. $2000 . \quad$ Model Pembelajaran Kooperatif. Surabaya: Universitas Negeri Surabaya.

Nasuitin, S. 2000. Berbagai Pendekatan dalam Proses Belajar dan Mengajar. Jakarta: Bumi Aksara.

Jurnal Pendidikan Indonesia | 110 
Nunan, David. 1991. Language Teaching Methodelogy: A Texbook for Teachers. New York: Printice Hall.

Nurjaya, Gede. 2009. Penggunaan Model Pembelajaraan Kooperatif Jigsaw pada Pembelajaran Metode Pembelajaran Bahasa dan Sastra Indonesia untuk Meningkatkan Pemahaman dan Kemampuan Aplikatif Mahasiswa. Laporan Penelitian (tidak diterbitkan). Undiksha: Singajara

Nurjaya, Gede. 2010. Pengembangan Bahan Ajar Metode Pembelajaran Bahasa dan Sastra Indonesia Berbasis Pembelajaran Kooperatif Jigsaw untuk Meningkatkan Pemahaman dan Kemampuan Aplikatif Mahasiswa. Laporan Penelitian (tidak diterbitkan). Undiksha: Singaraja

Russel, J.D. 1974. Modular Instructional. A Guide to the Design, Selection, Utilization and Evaluation of Modular Materials. Minneapolish, Minnesota: Burgess.

Slavin, R. E. 1995. Cooperative learning. Second edition. Boston: Allyn and Bacon.

Sriasih, S.A.P. 2008. Telaah Buku Teks. Singaraja: Undiksha.

Suandi, Nengah, dkk. 2010. Pengembangan Materi Pembelajaran Mata Kuliah Aplikasi Bahasa Indonesia di Perguruan Tinggi Berorientasi Integrasi Nasional dan Harmoni Sosial. Laporan Penelitian (Tidak diterbitkan). Undiksha: Singaraja.

Suryosuroto, B. 1983. Sistem Pengajaran dengan Modul. Yogyakarta: Bina Aksara.

Winataputra, dkk. 1977. Panduan Operasional Penulisan Modul. Jakarta: Depdikbud-UT FKIP. 


\title{
MENINGKATKAN MUTU PEMBELAJARAN MENULIS ARGUMENTASI DI SEKOLAH DASAR KELAS V LABORATORIUM UNDIKSHA BERDASARKAN PENDEKATAN KONTEKS DAN PROSES BERMEDIAKAN GAMBAR
}

\author{
I Wayan Wendra ${ }^{1}$, I Made Sutama ${ }^{2}$, Putu Triyasa ${ }^{3}$ \\ ${ }^{1,2}$ Jurusan Pendidikan Bahasa dan Sastra Indonesia, Fakultas Bahasa dan Seni, Universitas \\ Pendidikan Ganesha, Singaraja, Indonesia \\ ${ }^{3}$ SD Laboratorium Universitas Pendidikan Ganesha, Singaraja, Indonesia
}

\begin{abstract}
Abstrak
Penelitian ini bertujuan untuk mengetahui penerapan pembelajaran menulis argumentasi di sekolah dasar kelas $\mathrm{V}$ Laboratorium Undiksha berdasarkan pendekatan konteks dan proses bermediakan gambar dapat: (1) meningkatkan aktivitas siswa dalam pembelajaran, (2) meningkatkan hasil belajar menulis argumentasi, dan (3) dapat mengetahui respon siswa terhadap penerapan pembelajaran tersebut. Rancangan penelitian ini adalah penelitian tindakan kelas yang dilakukan dua siklus. Penelitian dilakukan di kelas Vb SD Lab. Undiksha. Data penelitian dikumpulkan melalui observasi, tugas menulis argumentasi,, dan wawancara serta angket. Teknik analisis datanya adalah deskriptif kualitatif( untuk data masalah 1) dan deskriptif kuantitatif(untuk masalah 2 dan 3). Hasil penelitian menunjukkan bahwa penerapan pembelajaran menulis argumentasi berdasarkan pendekatan konteks dan proses bermediakan gambar dapat meningkatkan aktivitas siswa yakni sebelumnya pembelajaran berpusat pada guru, setelah tindakan pembelajaran berpusat pada siswa. Hasil belajar menulis argumentasi siswa juga meningkat yakni sebelumnya hasil belajarnya berkategori cukup, setelah tindakan berkategori baik, serta seluruh siswa merespon positif terhadap pelaksanaan pembelajaran tersebut.
\end{abstract}

Kata kunci: Mutu pemelajaran menulis argumentasi, pendekatan konteks, proses 


\begin{abstract}
The study aimed at finding out whether the implementation of argumentative writing instruction at Laboratory Elementary School Class V Undiksha based on context and process pictures mediated approaches could: (1) improve the students activities in the instructional process, (2) improve the students achievement in writing argumentative text, and (3) figure out the students responses towards the implementations of the instructional model. It was a classroom-based action research conducted at the Lab-Elementary School Undiksha class $\mathrm{V}$ in two different cycles. The data were collected by using observation, writing argumentative text assignment, and interview as well as questionnaires. The data were analyzed descriptive qualitatively(for data of problems 1), and descriptive quantitatively (for data of problems 2 and 3 ). The results indicated that the implantation of writing instructional model in argumentative text based on context and process pictures mediated approaches could improve the students the studens activities, that was before the action, the instructional activity was minly teacher centered, however, after the action the instructional activity was directing to students centered. The students achievement in writing before the action was in "moderate" category, while after the action improving into "good" category, in addition all students provided positive responses towards the implementation of the model.
\end{abstract}

Keywords: instructional quality in argumentative writing, context and process approaches

\section{PENDAHULUAN}

Walaupun keterampilan menulis telah diajarkan sejak lama dengan berbagai macam pendekatan, hasil pengajaran yang diharapkan belum dapat dicapai(Sutama,2010:1). Dijelaskan lebih lanjut, yang lebih parah lagi adalah pengajar pun enggan melaksanakan pembelajaran menulis. Keengganan ini salah satu faktor penyebabnya adalah ketidakmampuan pengajar sendiri dalam menulis. Ini menjadikannya tidak tahu jelas bagaimana semestinya menulis diajarkan, kecuali memberikan teori kepada pembelajar(Sutama,2010).

Hasil survei ke lapangan menunjukkan bahwa kondisi prestasi belajar menulis siswa SD kelas $\mathrm{V}$ Laboratorium Undiksha belum memadai yakni belum mencapai standar yang ditetapkan yakni rata-rata 70 . Apalagi dalam menulis argumentasi yang menuntut pemikiran yang lebih rumit dan jelimet. Hal ini dutunjukkan dari hasil pembelajaran menulis yang telah dilakukan selama ini. Sebagaimana yang telah dikemukakan oleh guru, bahwa upaya pembelajaran yang selama ini telah dilaksanakan adalah melalui menjelaskan teori menulis argumentasi berdasarkan contoh yang sudah ada, kemudian siswa ditugaskan membuat tulisan argumentasi sesuai dengan minat atau kesukaannya. Pembelajaran menulis tersebut hasilnya sebagai berikut. Dari jumlah 40 siswa nilai rata-rata kelasnya hanya 6,02 tergolong cukup, dan ada 4 siswa(10\%) yang tergolong gagal atau tidak lulus kalau dilihat dari batas kelulusan. Rincian lebih jauh adalah sebagai berikut: 12 orang (30\%) memperoleh nilai baik, 24 siswa(60\%) tergolong cukup, 4 siswa(10\%) tergolong kurang(Hasil wawancara dengan guru bahasa Indonesia kelas $\mathrm{V}$ SD Lab. Undiksha).

Cara lain yang juga pernah dilakukan sebagai alternatif adalah dengan 
memanfaatkan apa yang ada di sekitar lingkungan siswa karena tema bahasannya adalah memanfaatkan barang-barang bekas di lingkungan siswa. Pada awalnya agar siswa memiliki konsep, guru menjelaskan berdasarkan contoh tulisan yang sudah ada tentang argumentasi memanfaatkan barang bekas/sampah, kemudian siswa ditugaskan melihat secara langsung barang bekas/sampah di lingkungannya sendiri dengan pertimbangan karena masing anak memiliki lingkungan yang berbeda. Selanjutnya siswa diajarkan berargumentasi dengan ditugaskan menulis argumentasi. Adapun hasilnya adalah sebagai berikut. Nilai rata-rata kelas siwa adalah 6,39 masih tergolong cukup belum mencapai standar yang dinginkan. Ada 2 orang siswa (5\%) yang masih gagal dalam upaya meraih prestasi belajarnya. Rincian hasil secara rinci adalah sebagai berikut. Ada 5 siswa $(12,5 \%)$ hasilnya sangat baik, 14 siswa (35\%) tergolong baik, 19 siswa (47,5\%) tergolong cukup, dan 2 siswa (5\%) tergolong kurang atau gagal (Hasil wawancara dengan guru bahasa Indonesia kelas $\mathrm{V}$ Lab. Undiksha).

Di sisi lain, berdasarkan wawancara dengan beberapa siswa sebagai sampel terkait dengan hasil belajar yang diperoleh tersebut bahwa kesulitan yang dialami adalah mereka walaupun sudah mendapat penjelasan teori menulis dari guru juga sulit mengerti penjelasan guru dan tidak mengerti tulisan yang harus dibuat serta untuk apa dan sulit mengembangkannya menjadi tulisan yang sesuai dengan permintaan guru. Akibat dari kesulitan-kesulitan tersebut membuat mereka kurang senang saat pembelajaran menulis. Dari ungkapan tersebut, kalau diidentifikasi kesulitan siswa adalah pertama dalam hal mengertikan penjelasan teori menulis yang diberikan guru, kedua dalam hal tulisan yang bagaimana yang harus dikerjakan, dan ketiga tidak mengerti yaitu untuk apa membuat tulisan tersebut dan cara mengembangkan tulisan. Seluruh kesulitan tersebut mengakibatkan siswa kurang menyenangi pelajaran menulis.

Upaya yang dilakukan guru dalam pembelajaran menulis di sekolah yang telah disurvei cenderung hanya melalui pemberian penjelasan teori menulis, kemudian guru menugaskan siswa menulis dengan topik bebas atau ditentukan, dan akhirnya guru menilai hasil tulisan siswa.

Cara yang ditempuh oleh guru tersebut masih berorientasi produk bukan proses. Upaya tersebut tidak membimbing dan memberi pengalaman kepada siswa secara alamiah untuk menemukan sendiri dan belajar memecahkan masalahnya sendiri karena pola pembelajarannya masih berorientasi lebih banyak pada guru (teacher-oriented) yang semestinya pola pembelajaran diorientasikan pada siswa (student-oriented). Kelas masih berfokus pada guru sebagai sumber utama pengetahuan sehingga kurang memberdayakan siswa yaitu mendorong siswa mengkonstruksikan pengetahuan di benak mereka sendiri. Guru menjelaskan dengan ceramah walaupun dengan contoh mengharuskan siswa menghafal fakta-fakta sehingga siswa dalam proses belajar tidak mengalami secara alamiah. Oleh karena itu, miskonsepsi dan cara keliru yang dilakukan guru selama ini perlu segera dibenahi. Kondisi ini perlu segera diatasi yaitu dengan menemukan langkah-langkah praktis dalam pembelajaran menulis argumentasi.

Setelah berdiskusi antara peneliti dan guru dan menganalisis kurikulum serta didasarkan atas hasil identifikasi masalah yang ada, maka tindakan yang disepakati Jurnal Pendidikan Indonesia | 115 
akan dilakukan adalah pembelajaran menulis di kelas $\mathrm{Vb}$ yaitu menulis argumentasi yang tanpa penjelasan teori menulis yang menyulitkan siswa dengan memanfaatkan media gambar yang dekat dengan lingkungan atau kehidupan siswa dan disukai siswa yakni menerapkan pembelajaran menulis argumentasi di sekolah dasar berdasarkan pendekatan konteks dan proses bermediakan gambar. Diyakini bahwa ini adalah alternatif pemecahan masalah yang dipandang lebih tepat dalam meningkatkan mutu pembelajaran menulis argumentasi di sekolah dasar berdasarkan pendekatan konteks dan proses bermediakan gambar.

Berdasarkan uraian pada bagian pendahuluan di atas, maka rumusan masalah dalam penelitian ini adalah sebagai berikut. (1) Apakah pembelajaran menulis argumentasi berdasarkan pendekatan konteks dan proses bermediakan gambar dapat meningkatkan aktivitas siswa kelas $\mathrm{Vb}$ Lab. Undiksha dalam belajar menulis argumentasi? (2)Apakah pembelajaran menulis argumentasi berdasarkan pendekatan konteks dan proses bermediakan gambar dapat meningkatkan hasil belajar menulis argumentasi siswa SD Lab. Undiksha? (3) Bagaimana respon siswa terhadap pembelajaran menulis argumentasi berdasarkan pendekatan konteks dan proses bermediakan gambar yang telah diterapkan?

Hasil penelitian ini akan memberikan manfaat yang bersifat praktis. Manfaat praktis yang dimaksud terutama bermanfaat bagi pihak-pihak yang terlibat dalam dunia pendidikan, dengan rincian sebagai berikut. (1) Bagi para siswa, penelitian ini akan sangat beramanfaat karena secara tidak langsung mereka terbantu dalam mengikuti pembelajaran menulis argumentasi yang sangat memberi peluang bagi mereka yang kreatif akan dapat meningkatkan hasil belajar secara lebih optimal. Hal ini disebabkan oleh pendekatan konteks dan proses yang dapat memberi peluang kreatif, berinteraksi dan berkarya seluas-luasnya dengan temannya yang cukup hiterogen. (2) Bagi guru bahasa Indonesia, temuan penelitian ini dapat membuka wawasan guru dan dapat menjadikan startegi alternatif dalam mengelola pembelajaran menulis berdasarkan pendekaan konteks dan proses sehingga dapat meningkatkan mutu pembelajaran menulis di sekolah. (3) Bagi dosen, hasil penelitian ini akan memberi gambaran kondisi riil pembelajaran menulis di lapangan sehingga dapat mengantisipasi dalam merancang perkuliahan yang sesuai dengan tantangan riil di lapangan bagi para mahasiswa calon guru bahasa Indonesia. (4) Bagi pengambil kebijakan di Depdikbud, temuan penelitian ini dapat dijadikan acuan strategi pembelajaran menulis dalam meningkatkan mutu pembelajaran menulis di Sekolah Dasar.

Tindakan yang ditempuh untuk mengatasi masalah di atas didasarkan atas pemikiran berikut. Temuan-temuan dari psikologi kognitif menyediakan teori dasar untuk memperbaiki pembelajaran secara umum. Premis dasar dalam psikologi kognitif adalah bahwa belajar merupakan proses pengkonstruksian pengetahuan baru berdasarkan pengetahuan yang sudah ada sekarang. Menurut Glaser ( dalam Gijselaers, 1996), belajar merupakan proses konstruktif dan bukan proses penerimaan. Proses kognitif yang disebut metakognisi mempengaruhi penggunaan pengetahuan dan faktor sosial dan kontekstual mempengaruhi pembelajaran. Dengan demikian karakteristik pembelajaran perlu Jurnal Pendidikan Indonesia | 116 
perubahan karena pembelajaran bukanlah sekadar pengisian kepala siswa dengan sejumlah imformasi, dan pikiran siswa bukanlah sebagai kotak kosong yang dapat diisi melalui pengulangan dan latihan semata. Pembelajaran harus dapat memberdayakan siswa untuk terlibat aktif secara fisik dan mental agar siswa terbiasa mandiri, cerdas, kritis dan kreatif menghadapi tantangan kehidupan.

Menurut Dankin dan Biddle (1974) proses pembelajaran merupakan variabel sentral yang berpengaruh secara langsung terhadap hasil belajar. Kualitas pembelajaran dapat dilihat dari segi proses dan hasil. Dari segi proses, pembelajaran yang berkualitas ditunjukkan dengan adanya motivasi peserta didik untuk terlibat secara aktif dalam kegiatan pembelajaran yakni peserta didik senang dan antusias mengikuti kegiatan pembelajaran. Dari segi hasil, kualitas pembelajaran dengan ditunjukkan dengan adanya pencapaian tujuan atau hasil pembelajaran oleh peserta didik.

Kehadiran Kurikulum berbasis kompetensi tentu saja diharapkan dapat membekali peserta didik agar dapat menghadapi tantangan kehidupan secara mandiri, cerdas, kritis, rasional dan kreatif. Pada buku pedoman KBK tahun 2001 dan direvisi tahun 2003 oleh Depdiknas disebutkan ada 5 ciri KBK sebagai berikut: (1) menekankan pada ketercapaian kompetensi siswa, baik secara individual maupun klasikal, (2) berorientasi pada hasil belajar (learning autcomes) dan keragaman, (3) penyampaian dalam pembelajaran menggunakan pendekatan dan metode yang bervariasi, (4) sumber belajar bukan hanya guru tetapi juga sumber belajar lainnya yang memenuhi unsur edukatif, dan (5) penilaiannya menekankan pada proses dan hasil belajar dalam upaya penguasaan atau pencapaian suatu kompetensi (Balitbang Depdiknas, 2001,2002:5). Untuk itu sangat diperlukan upaya pembelajaran yang dapat memenuhi harapan kurikulum tersebut.

Dari uraian tersebut di atas, maka dapatlah ditegaskan bahwa mutu suatu pembelajaran akan dapat dilihat dari segi proses dan dari segi hasil pembelajaran. Dari segi proses, pembelajaran yang bermutu ditunjukkan dengan adanya motivasi peserta didik untuk terlibat secara aktif dalam kegiatan pembelajaran yakni peserta didik senang dan antusias mengikuti kegiatan pembelajaran. Dari segi hasil, kualitas pembelajaran dengan ditunjukkan dengan adanya pencapaian tujuan atau hasil pembelajaran oleh peserta didik. Implementasi kurikulum berbasis kompetensi dengan pendekatan kontektual(contextual teaching learning) mengarah pada upaya meningkatkan mutu pengajaran dan pembelajaran di tingkat pendidikan dasar dan menengah untuk mempersiapkan para peserta didik menghadapi tantangan masa depan. Pendekatan kontekstual diperkenalkan kepada guru adalah konsep belajar yang membantu guru mengaitkan materi-materi yang diajarkannya dengan situasi dunia nyata siswa (Direktorat Jendral Pendidikan Dasar dan Menengah, 2002: iii). Lebih lagi dalam kegiatan menulis karena ada pandangan bahwa menulis adalah aktivitas sosial. Sebagai aktivitas sosial, menulis tidak pernah dilakukan dalam situasi vakum tanpa konteks. Menulis adalah tindak komunikasi, sebagai upaya membagi hasil observasi, inforamasi, pikiran atau ide, dan pengalaman kepada orang lain (Cohen dan Riel, 1989). Hal ini telah didukung oleh hasil penelitian yang telah peneliti lakukan yakni penelitian tentang pembelajaran kontekstual Jurnal Pendidikan Indonesia | 117 
melalui mengobservasi objek otentik dapat meningkatkan mutu(proses dan hasil) pembelajaran menulis deskripsi siswa SMPN4 Singaraja(Wendra,2009). Bahkan hasil penelitian ini telah dipilih oleh Puslit Undiksha untuk disosialisasikan kepada guru-guru SD, SMP,SMA melalui seminar tingkat Provinsi tahun 2010 di Klungkung(Desiminasi Hasil Penelitian Dosen Undiksha oleh Puslit Undiksha,2010).

Dalam kaitannya dengan menulis argumentasi, Winch dkk(2006) menegaskan bahwa wacana argementasi yang cenderung bersifat analitis lebih sulit dipahami oleh anak-anak. Ini adalah tantangan bagi guru untuk dapat memudahkan anak dalam belajar menulis dengan menggunakan alternatif pendekatan serta teknik yang cocok dengan kondisi anak. Sutama(2010) menegaskan bahwa pada jenjang sekolah dasar, pada kelas peralihan dari kelas rendah ke kelas tinggi,pembelajaran menulis wacana mulai diperkenalkan dan ditegaskan bahwa pendekatan yang cocok diterapkan adalah pendekatan konteks. Dikatakan demikian karena pada jenjang ini siswa belum bisa diajak berbicara banyak tentang teori menulis. Pemaksaan memperkenalkan istilah-istilah teknis dalam menulis justru akan semakin membingungkan siswa. Sebaliknya, dengan hanya memberi konteks menulis, terutama tujuan menulis, seperti menceritakan, membedakan, atau memberi pendapat tentang sesuatu, siswa pada jenjang itu akan dapat memproduksi tulisan dengan pola yang sesuai. Pendekatan konteks akan dipadukan dengan pendekatan proses. Pendekatan proses akan mengajak siswa dalam situasi menulis proses menulis yang sebenarnya yakni melalui tahapan menulis yang terdiri dari beberapa tahap, yaitu tahap perencanaan,tahap penuangan, dan tahap peninjauan. Penerapan pendekatan ini di dalam pembelajaran menulis adalah siswa dibantu memahami proses menulis dan membangun repertoir strategi pramenulis,menulis, meninjau dan menulis ulang. Lebih lanjut siswa dituntun menjalani proses ini dengan harapan mereka dapat menghasilkan tulisan yang baik. Dengan memadukan pendekatan konteks dan proses dalam belajar menulis argumentasi di sekolah dasar, maka pendekatan konteks akan menghindari penjelasan teori menulis yang bersifat teknis yang menyulitkan dan membingungkan siswa menulis apa dan untuk apa. Pendekatan proses akan menuntun dan membantu siswa dalam proses menulis mulai dari merencanakan dengan mendiskusikan topik, kemudian proses penuangan, lalu peninjauan untuk revisi dan akhirnya menulis ulang. Sedangkan penggunaan gambar yang dekat denga kehidupan siswa dan disukai siswa akan memotivasi siswa untuk belajar menulis Berdasarkan hal itu, pembelajaran menulis argumentasi berdasarkan pendekatan konteks dan proses bermediakan bambar akan dapat meningkatkan mutu pembelajaran menulis argumentasi di sekolah dasar.

Dari uraian tersebut di atas, maka dapatlah ditegaskan bahwa mutu suatu pembelajaran akan dapat dilihat dari segi proses dan dari segi hasil pembelajaran. Dari segi proses, pembelajaran yang bermutu ditunjukkan dengan adanya motivasi peserta didik untuk terlibat secara aktif dalam kegiatan pembelajaran yakni peserta didik senang dan antusias mengikuti kegiatan pembelajaran. Dari segi hasil, kualitas pembelajaran dengan ditunjukkan dengan adanya pencapaian tujuan atau hasil pembelajaran oleh peserta didik.

Jurnal Pendidikan Indonesia $\mid 118$ 
Terkait dengan menulis argumentasi, ada pandangan bahwa menulis adalah aktivitas sosial (Hull dalam Sutama, 2010). Lebih lanjut ditegaskan, sebagai aktrivitas sosial, menulis tidak pernah dilakukan dalam situasi vakum. Menulis adalah tindak komunikasi, sebagai upaya membagi hasil observasi, informasi, pikiran atau ide, dan pengalaman kepada orang lain. Argumentasi tidak lain dari usaha untuk mengajukan bukti-bukti atau menentukan kemungkinan-kemungkinan untuk mengetahui sikap atau pendapat mengenai suatu hal. Tulisan argumentasi adalah suatu tulisan yakni penulis berusaha merangkaikan fakta-fakta sedemikian rupa sehingga ia mampu menunjukkan apakah suatu pendapat atau suatu hal tertentu itu benar atau tidak(Keraf, 2004). Tujuannya adalah untuk mempengaruhi sikap dan pendapat orang lain, agar mereka itu percaya dan pada akhirnya sesuai dengan apa yang diinginkan pembicara atau penulis (Keraf,2004:3). Struktur argumentasi secara umum memuat aspek pendahuluan, tesis, alasan/bukti, dan simpulan. Dalam bentuk mini (wacana singkat) sebuah argumentasi dapat berwujud sebuah paragraf yang di dalamnya minimal ada tesis dan alasan. Hal ini senada dengan pendapat Toulmin(1979:33) bahwa pola dasar sebuah argumentasi terdiri atas tesis dan bukti/alasan. Tesis yang dimaksud adalah pernyataan yang menunjukkan sikap penulis terhadap topik tulisan yang akan dibuktikan dalan paparan pendapatnya. Untuk menghasilkan pernyataan tesis, seorang penulis dapat merumuskan pertanyaan yang berkaitan dengan topik tulisan,lalu menjawabnya. Jawaban yang sudah dianggap mantap itulah yang merupakan pernyataan tesis.
Dalam berargumentasi seseorang dapat merangkai fakta-fakta atau bukti-bukti sedemikian rupa sehingga mampu menunjukkan apakah suatu pendapat itu benar atau tidak. Dengan demikian mengajukan argumentasi merupakan kemampuan menyatakan dan menyampaikan fakta-fakta serta bukti-bukti untuk menunjukkan benar tidaknya suatu pendapat melalui penggunaan bahasa.

Bormann(1991:192)

mengemukakan tiga hal yang dapat dihubungkan dengan argumentasi. Ketiga tersebut yaitu (1) argumentasi dapat dihubungkan dengan pokok masalah yang ditampilkan sebagai pertanyaan terhadap kenyataan; (2) argumentasi dapat dihubungkan dengan pertanyaaan mengenai nilai-nilai; (3) argumentasi dapat dihubungkan dengan pertanyaan mengenai kebijakan.

Dalam pembelajaran menulis argumentasi ini, akan dihubungkan dengan butir satu yaitu argumentasi yang dihubungkan dengan pokok masalah. Masalah yang dimaksud adalah hal atau masalah yang dekat dengan kehidupan siswa dan disukai siswa dengan bermediakan gambar. Topik yang ditetapkan dalam pembelajaran menulis argumentasi harus didasarkan oleh sejumlah pertimbangan yang matang. Topik yang ditetapkan hendaknya sesuai dengan tingkat pengajaran dan minat siswa. Menurut Piaget(dalam Santyasa dan Sukadi,2008), usia SD yang masih berada pada tahapan operasi konkret sangat memerlukan objekobjek konkret sebagai pijakan untuk memandu belajarnya. Objek-objek konkret yang ada di lingkungan mereka atau bendabenda artivisial dapat digunakan sebagai fasilitas belajar terpadu. Benda-benda tersebut merupakan objek anak untuk Jurnal Pendidikan Indonesia | 119 
bermain dan merangsang rasa ingin tahunya secara optimal. Rasa ingin tahu yang bangkit melalui proses bermain dapat merangsang mereka untuk mengekpresikan dunia dan membangkitkan kompetensi pemecahan masalah.

Pakar lain mengatakan bahwa topik dengan media gambar adalah penyajian topik yang bersifat non verbal yang dimaksudkan untuk menghindari penjelasan teori oleh guru yang jelimet dan membosankan siswa. Weir (1990:62) mengatakan bahwa keuntungan stimulus nonverbal jika mampu menyajikan menyajikan informasi secara jelas dan tepat, akan memungkinkan siswa untuk tidak berlama-lama menghasilkan tulisan. Tugas menulis dengan menyajikan materi nonverbal akan semakin efektif jika meminta siswa mengomentari kecenderungan tertentu yang tampak dalam grafik, atau membandingkan dan mmpertentangkan sepasang gambar yang berbeda.

Terkait dengan pembelajaran dengan media gambar Wright(1992) mengatakan bahwa gambar dapat memainkan sejumlah peran: (1) Gambar dapat memotivasi murid dan menarik perhatian mereka. (2) Gambar dapat memberikan konteks penggunaan bahasa dan membawa dunua nyata ke dalam kelas. (3) Gambar dapat bercerita sebagaimana adanya, diinterpretasikan, atau dikomentari secara subjektif. (4) Gambar dapat memberikan isyarat tentang jawaban suatu pertanyaan. (5) Gambar dapat memberi stimulus dan informasi untuk diacu dalam bercakap-cakap, berdiskusi dan bercerita. Dengan uraian di atas jelaslah bahwa pembelaran menulis argumentasi akan sangat efektif dengan penyampaian materi dengan bermediakan gambar.
Terkait dengan pendekatan, ada sejumlah pendekatan dalam pembelajaran menulis, yaitu pendekatan konteks, pendekatan proses dan pendekatan pola(Reimes,1991). Pendekatan konteks mengasumsikan bahwa di dalam aktivitas menulis yang sesungguhnya penulis berorientasi pada tujuan menulis dan pembaca yang menjadi sasaran tulisan. Implementasi dari penerapan pendekatan ini di dalam pembelajaran di kelas adalah siswa ditugasi untuk menulis dengan tujuan dan pembaca yang telah dispesifikasi. Lebih lanjut dengan spesifikasi semacam itu, diharapkan siswa dapat menghasilkan tulisan dengan pola retorika yang baik.

Pada jenjang sekolah dasar dimana pembelajaran menulis wacana mulai diperkenalkan, pendekatan konteks cocok diterapkan. Dikatakan demikian karena pada jenjang itu, siswa belum bisa diajak berbicara banyak tentang teori menulis. Pemaksaan memperkenalkan istilah-istilah teknis dalam menulis justru akan semakin membingungkan siswa. Sebaliknya, dengan hanya memberikan konteks menulis, terutama tujuan menulis, seperti meceritakan, membedakan atau memberi pendapat tentang sesuatu, siswa pada jenjang itu akan dapat memproduksi tulisan dengan pola yang sesuai. Leki dkk(2008) menyatakan, "In supprtive,meaning-oriented writing contexts, beginning L2 writers brought with them and were able to draw upon a variety of resources and strategies to succesfully create expresive texts that communicated meaning."

Pendekatan proses di sisi lain mengasumsikan bahwa menulis terdiri atas beberapa tahap, yaitu: tahap perencanaan,tahap penuangan, dan tahap peninjauan. Aktivitas pramenulis, berdiskusi di dalam kelompok menulis, dan mencobaJurnal Pendidikan Indonesia | 120 
coba menulis akan membantu mengembangkan kelancaran menulis, sekaligus mengatasi kemacetan dalam menulis yang diakibatkan oleh keterbatasan memori(Myers dalam Sutama,2010). Penerapan pendekatan ini dalam pembelajaran menulis adalah siswa dibantu memahami proses menulis dan membangun repertoire strategi menulis, menulis, meninjau, dan menulis ulang. Lebih lanjut, siswa dituntut menjalani proses ini dengan harapan mereka dapat menghasilkan tulisan yang baik.

Dengan pendekatan konteks, siswa tidak akan merasa bahwa menulis dilakukan hanya untuk memenuhi tugas dari guru, tetapi akan merasa berkomunikasi untuk mencapai tujuan tertentu dengan pembaca sasaran yang ditetapkan. Dengan pendekatan proses, kekurangan siswa dalam pengetahuan tentang topik yang akan ditulis akan teratasi melalui diskusi pramenulis dibantu media gambar, kelancaran mereka dalam menulis tidak akan terganggu oleh hal-hal yang bersifat gramatikal, dan kerendahan mutu tulisan mereka akan ditingkatkan melalui proses peninjauan atau revisi. Dengan penerapan kedua pendekatan yakni pendekatan konteks dan pendekatan proses yang bermediakan gambar mutu pembelajaran menulis argumentasi akan dapat ditingkatkan.

\section{METODE PENELITIAN}

Penelitian ini tergolong penelitian tindakan kelas. Sesuai dengan sifatnya, penelitian tindakan kelas bersifat siklikal yang dilaksanakan secara multisiklus. Secara garis besarnya, kegiatan setiap siklus meliputi: refleksi awal, perencanaan tindakan, pelaksanaan tindakan, observasi/evaluasi, dan refleksi untuk menentukan rencana tindakan pada siklus berikutnya (Kemmis dan McTaggart, 1998).

Subyek penelitian ini adalah satu kelas yaitu siswa kelas $\mathrm{Vb}$ beserta pelaksana pemberi tindakan di kelas itu yakni guru pengajarnya. Pihak yang dilibatkan dalam penelitian ini ialah dua dosen dan seorang guru kelas Vb SD Lab. Undiksha Singaraja, yang berkolaborasi dalam proses penelitian ini mulai dari perencanaan, pelaksanaan, sampai penyusunan laporan.

Rincian kegiatan memulai siklus 1adalah sebagai berikut. (1) Guru memberikan orientasi materi pelajaran beserta model pembelajaran yang akan diterapkan, sumber yang digunakan, serta penegasan kemampuan yang akan dilatihkan. (2) Siswa dibagi dalam 5 kelompok, dengan cara guru menghitung siswa, satu, dua, tiga, empat, dan lima. Yang nomor satu masuk kelompok satu, yang nomor dua masuk kelompok dua dan seterusnya. (3) Guru bersama siswa menetapkan topik disukai siswa dan membagi gambar benda yang telah disiapkan untuk topik tulisan, kemudian dibagikan juga blangko untuk mencatat hasil pencermatan siswa terhadap gambar. (4) Guru bersama siswa menetapkan tujuan menulis dan sasaran tulisan. (5) Siswa mencermati gambar benda tersebut dan mengidentifikasi kelebihan atau keunggulan yang ada pada benda tersebut dan diungkapkan dalam bentuk kalimat. (6) Setelah 20 menit, secara bergantian masing-masing kelompok ke depan kelas mengemukakan secara lisan hasil observasinya. Setelah itu kelompok lain menanggapinya, boleh bertanya atau memberikan masukan/pendapat yang terkait dengan hasil pendapat temannya dan penataannya sebagai persiapan menulis 
(argumentas)i. (7) Siswa ditugaskan menyusun sebuah paragraf (argumentasi) berdasarkan data yang diperoleh saat mencermati dan berdasarkan hasil penyempurnaan saat diskusi secara klasikal. (8) Guru dengan melibatkan siswa membahas(mengoreksi) hasil kerja siswa yang berupa tulisan (argumentasi) menyangkut kelebihan dan kekurangan tulisan yang sudah dibuat dan merevisinya. (9) Guru menugaskan siswa menulis ulang berdasarkan hasil koreksi dan revisi yang telah dilakukan.

Selama pelaksanaan tindakan, peneliti secara kolaboratif melakukan observasi terhadap keseluruhan pelaksanaan tindakan baik mengobservasi guru maupun siswa.

Peneliti secara kolaboratif bersama guru sebagai anggota peneliti melakukan refleksi. Refleksi dilaksanakan pada setiap akhir pembelajaran yaitu berkenaan dengan kendala dan masalah yang dialami guru maupun siswa, alokasi waktu mengerjakan tugas, hasil belajar, dan respon siswa terhadap pembelajaran yang telah berlangsung. Hasil refleksi tersebut selanjutkan digunakan sebagai dasar untuk menyempurnakan tahapan-tahapan penelitian pada siklus berikutnya.

Data yang diperlukan dalam penelitian ini adalah (1) data tentang aktivitas siswa dalam pembelajaran menulis argumentasi, dikumpulkan dengan metode observasi, (2) data tentang respon siswa terhadap pembelajaran menulis argumentasi, dikumpulkan dengan metode wawancara dan angket, dan (3) data tentang hasil belajar menulis argumentasi dikumpulkan dengan metode penugasan menulis argumentasi. Penerapan masingmasing metode akan dibantu dengan instrumen masing-masing. Semua data tersebut diperlukan untuk melakukan refleksi dan menarik kesimpulan pada setiap akhir siklus.

Kriteria keberhasilan tentang aktivitas siswa, ditunjukkan dengan terjadinya perubahan aktivitas pembelajaran yang dilakukan guru yang semula berpusat pada guru menjadi berpusat pada siswa, dan terajadi perubahan interaksi dari dua arah menjadi multi arah. Kriteria keberhasilan dari respon siswa yakni $80 \%$ dari jumlah siswa merespon positif terhadap pelaksanaan pembelajaran. Kriteria keberhasilan hasil belajar menulis argumentasi ditunjukkan dengan keberhasilan perolehan rata-rata kelas pada kategori baik, atau $80 \%$ dari jumlah siswa memperoleh nilai kategori baik.

Data tentang aktivitas siswa dalam pembelajaran menulis argumentasi dianalisis secara deskriptif kualitatif. Data tentang respos siswa terhadap penerapan pembelajaran dianalisis secara deskriptif kuantitatif. Penilaian alternatif respon terdiri dari sangat tinggi (skor 5), tinggi(skor 4), cukup (skor3), rendah (skor 2), dan sangat rendah(skor 1). Rerata skor respon seluruh siswa dihitung dengan cara jumlah skor seluruh respon siswa dibagi jumlah siswa. Setelah itu akan dikonversikan dengan kriteria respon siswa yang diadaptasi dari model penilaian Nurkancana dan Sunartana(1996). Dengan demikian akan diperoleh gambaran tingkat respon yakni sangat positif, positif, cukup positif,kurang positif, dan sangat kurang positif.

Data tentang hasil belajar menulis argumentasi dianalisis secara deskriptif kuantitatif yaitu tulisan yang dihasilkan siswa diberi skor dengan menggunakan panduan model "Profil Penilaian Karya Tulis" yang diadaptasi dari Jurnal Pendidikan Indonesia | 122 
"ESL Composition Profile" (Jacobs dkk., 1981),baik dari segi isi tulisan yaitu kelengkapan unsur-unsur objek yang harus diargumentasikan maupun organisasi tulisan yaitu sistematika atau keruntutan penjelasan objek. Dengan mengacu pada profil ini, skor maksimal yang bisa dicapai siswa adalah 100 (60 dari komponen isi, dan 40 dari komponen organisasi).

\section{HASIL PENELITIAN DAN PEMBAHASAN}

Diperlukan dua siklus untuk dapat mencapai hasil penelitian ini. Pada siklus 1 media gambar yang digunakan adalah hadiah yang berupa tas sekolah yakni pilih tas ransel dan tas selempang yang memakai tali. Tampak pembelajaran berpusat pada siswa baik saat diskusi kelompok maupun saat diskusi antar kelompok. Interaksi terjadi multi arah yakni dari siswa dengan siswa dalam diskusi kelompok dan antar kelompok juga terjadi interaksi antar siswa dan siswa juga kepada guru sebagai pemandu jalannya diskusi secara klasikal saat diskusi antar kelompok yakni penyajian hasil diskusi kelompok.

Hasil pembelajaran menulis argumentasi skor rata-rata yang diperoleh pada siklus 1 ini adalah 75 tergolong baik. Sejumlah 4 siswa (13\%) memperoleh nilai berkategori sangat baik, sejumlah 19 siswa (63\%) memperoleh nilai berkategori baik, dan 7 siswa (24\%) memperoleh nilai berkategori cukup. Hasil ini yakni penerapan pembelajaran menulis argumentasi berdasarkan pendekatan konteks dan proses bermediakan gambar telah menampakkan peningkatan hasil yang lebih baik dibandingkan dengan skor rata-rata yang diperoleh saat refleksi awal yang hanya pada kategori cukup. Kelemahan tulisan yang masih tampak adalah hanya dari segi bentuk paragraf. Memulai paragraf tidak menjorok kedalam dan rata pinggir kanan dan kiri. Ada kalimat yang dibuat tidak dimulai dengan huruf besar dan diakhiri dengan tanda titik.

Hasil tentang respon siswa diperoleh adalah sebagai berikut. Hampir semua siswa yaitu 95\% dari jumlah siswa dan merespon positif pelaksanaan pembelajaran ini. Mereka merespon positif karena merasa terbantu dan menjadi lebih mudah dalam menghasilkan tulisan. Melalui kegiatan pencermatan gambar untuk melihat keunggulan yang dipilih sebagai bahan alasan atau argumentasi yang diungkap dalam bentuk kalimat, sehingga dalam menulis menjadikan paragraf tinggal menyusun dan menghubungkan saja satu kalimat dengan kalimat lainnya. Adanya kegiatan diskusi kelompok mereka merasa terbantu dalam menemukan ide lebih lengkap sebagai bahan argumentasi dan mereka menjadi lebih yakin lagi atas temuannya melalui diskusi antar kelompok melalui penyajian hasil di depan kelas. Ada beberapa siswa mengalami kesulitan sedikit terutama dalam menghubungkan kalimat yakni menggunakan piranti penghubung yang tepat ketika merangkai kalimat yang ada menjadikan paragraf argumentasi yang padu. Ini terjadi jika urutan ide alasan tidak ditata secara beraturan.

Setelah melalui refleksi siklus 1 dengan perubahan dan perbaikan terhadap kelemahan yang ada pada siklus 1 . Pembelajaran menulis argumentasi pada siklus 2 bermediakan gambar sepeda sebagai hadiah yang harus dipilih siswa yaitu sepeda gunung dan sepeda ontel yang antik dan unik. Hampir semua siswa aktif terlibat dalam diskusi untuk berusaha menemukan ide keunggulan atau kelebihan benda yang menjadi pilihannya. Tampak ketua kelompok aktif mencatat temuan idea Jurnal Pendidikan Indonesia | 123 
atau pemikiran anggotanya. Demikian halnya saat diskusi antar kelompok yakni saat penyajian hasil salah satu kelompok yang dianggap terbaik hasil kerjanya ke depan kelas. Semua siswa tampak antusias untuk berpendapat tanpa keraguan, bahkan berebutan sehingga terkesan agak rebut. Sehingga dalam diskusi antar kelompok ini pelaksana tindakan tidak lagi melakukan upaya pemancingan justru tinggal mengendalikan agar diskusi berjalan dengan tertib dan agar tidak terkesan rebut.

Hasil evaluasi terhadap tulisan paragraf argumentasi yang dikerjakan siswa pada siklus 2 diperoleh hasil sebagai berikut. Nilai rata-rata kelas sebesar 83,5 berkategori baik. Siswa yang memperoleh nilai sangat baik sejumlah 16 siswa (53\%), sedangkan siswa yang memperoleh nilai berkategori baik sejumlah 14 siswa (47\%), dan tidak ada siswa yang memperoleh nilai berkategori cukup. Jadi semua siswa telah mencapai target KKM yang ditargetkan sekolah yakni nilai sebesar 70 . Perolehan nilai rata-rata pada siklus II sebesar 83,5 ini telah mengalami peningkatan dibandingkan dengan nilai rata-rata yang dperoleh pada siklus I yakni 75 . Kesalahan yang dilakukan siswa pada siklus I tidak tampak lagi pada siklus II ini.

Siswa sangat antusia dan merespon positif perhadap pelaksanaan pembealajaran Hal ini tampak dari hasil angket dan wawancara adalah sebagai berikut. Semua siswa (100\%) memberikan respon positif terhadap penerapan pembelajaran ini. Adapun alasannya adalah sebagai berikut. Mereka merasa senang karena dapat melihat dalam gambar dengan jelas hadiah yang akan diberikan untuk dipilih dan hadiahnya bagus-bagus yang memang disukainya yakni baik berupa tas sekolah maupun sepeda. Dengan diskusi bersama teman menjadi lebih mudah menemukan hal yang dianggap menarik untuk dijadikan alasan dalam menulis argumentasi. Tambah lebih yakin lagi dengan adanya teman yang tampil ke depan kelas sebagai wakil kelompok yang membantu untuk menemukan alasan dan mengurut alasan yang akan dibuat dalam tulisan. Mereka terasa terbantu dan lebih mudah ketika merangkainya menjadi sebuah paragraf argumentasi. Dengan demikian dapatlah ditegaskan bahwa siswa merespon positif cara pembelajaran menulis argumentasi yang telah diterapkan.

Melalui refleksi atas hasil observasi, skor yang dicapai dalam menulis argumentasi, dan hasil wawancara serta angket, dapatlah disimpulkan bahwa pembelajaran menulis berdasarkan pendekatan konteks dan proses bermediakan gambar dapat meningkatkan kualitas proses dan hasil belajar menulis argumentasi siswa sekolah dasar kelas $\mathrm{V}$ Laboratorium Undiksha.

Meningkatkan mutu pembelajaran merupakan tujuan dilaksanakan pembelajaran untuk mencapai tujuan pembelajaran secara maksimal. Indikator mutu pembelajaran dapat dilihat dari segi proses aktivitas pembelajaran dan dari segi hasil yang dicapai dalam pembelajaran. Gambaran akan lebih lengkap lagi dari pelaksanaan pembelajaran tersebut kalau dilengkapi dengan diketahuinya respon siswa terhadap pembelajaran yang dilaksanakan. Untuk itu, penelitian terhadap masalah tersebut dalam penelitian ini akan memberikan sumbangan yang bermanfaat bagi pelaksaan suatu pembelajaran.

Berdasarkan hasil penelitian ditemukan bahwa penerapan pembelajaran menulis argumentasi berdasarkan pendekatan konteks dan proses 
bermediakan gambar dapat meningkatkan hasil belajar menulis argumentasi siswa SD Lab. Undiksha. Hal ini sudah tentu bisa terjadi. Pada jenjang sekolah dasar saat pembelajaran menulis wacana diperkenalkan, pendekatan konteks sangat cocok dan tepat diterapkan. Dikatakan demikan karena pada jenjang ini, siswa belum bisa diajak berbicara banyak tentang teori menulis. Pemaksaan memperkenalkan istilah-istilah teknis dalam menulis justru akan semakin membingungkan siswa(Sutama, 2010). Sebaliknya, dengan hanya memberikan konteks menulis, terutama tujuan menulis, seperti menceritakan, membedakan atau member pendapat tentang sesuatu, siswa pada jenjang ini akan dapat memproduksi tulisan dengan pola yang sesuai. Leki dkk(2008) menyatakan, "In supprtive, meaning-oriented writing contexts, beginning L2 writers brought with them and were able to draw upon a variety of resources and strategies to succesfully create expresive texts that communicated meaning." Di sisi lain penerapan pendekatan proses pembelajaran menulis terdiri atas beberapa tahap, yaitu: tahap perencanaan,tahap penuangan, dan tahap peninjauan. Aktivitas pramenulis, berdiskusi di dalam kelompok menulis, dan mencoba-coba menulis akan membantu mengembangkan kelancaran menulis, sekaligus mengatasi kemacetan dalam menulis yang diakibatkan oleh keterbatasan memori(Myers dalam Sutama,2010).

Hasil penelitian juga menunjukkan bahwa pembelajaran menulis argumentasi berdasarkan pendekatan konteks dan proses bermediakan gambar dapat meningkatkan aktivitas siswa dalam belajar menulis. Penerapan pendekatan ini dalam pembelajaran menulis adalah siswa dibantu dibimbing melalui tahapan proses menulis yakni mulai dari tahap perencanaan atau pramenulis, tahap penuangan dan tahap peninjauan. Lebih lanjut, siswa dituntut aktif menjalani proses ini dengan harapan mereka dapat menghasilkan tulisan yang baik. Pada tahap perencanaan melalui diskusi kelompok siswa berusaha bertukar pendapat menemukan ide gagasan yang dapat digunakan sebagai alasan atau argumentasi. Melalui pejajian hasil kelompok dan diskusi antar kelompok menuntut siswa untuk aktif baik dalam penambahan ataupun pengurangan ide serta penataan ide yang akan digunakan sebagai bahan menulis argumentasi. Dengan penerapan kedua pendekatan yakni pendekatan konteks dan pendekatan proses hasil pembelajaran dapat ditingkankan juga ativitas siswa dalam belajar dapat ditingkatkan. Dengan mikian mutu pembelajaran menulis argumentasi dapat ditingkatkan. Hasil penelitian sejenis juga mengungkapkan bahwa pembelajaran kontekstual melalui mengobservasi objek otentik dapat meningkatkan mutu pembelajaran menulis (Wendra,2009).

Hasil penelitian juga menunjukkan bahwa siswa merespon positif terhadap pembelajaran menulis argumentasi yang telah diterapkan. Hal ini tentu saja bisa terjadi karena dengan pendekatan proses siswa tidak dijejali dengan teori-teori menulis yang membosankan anak tingkat SD, sedangkan pendekatan proses mengajak siswa mengalami langsung dalam dalam menulis melalui diskusi dengan temannya. Sehingga siswa menjadi senang dalam belajar karena tanpa banyak beban dan tekanan. Lebih-lebih dibantu dengan media gambar yang dekat dengan kehidupan siswa dan disukai siswa. Menurut Piaget(dalam Santyasa dan Sukadi,2008), usia SD yang masih berada pada tahapan Jurnal Pendidikan Indonesia | 125 
operasi konkret sangat memerlukan objekobjek konkret sebagai pijakan untuk memandu belajarnya. Terkait dengan pembelajaran dengan media gambar Wright(1992) mengatakan bahwa gambar dapat memainkan sejumlah peran: (1) Gambar dapat memotivasi murid dan menarik perhatian mereka. (2) Gambar dapat memberikan konteks penggunaan bahasa dan membawa dunia nyata ke dalam kelas. (3) Gambar dapat bercerita sebagaimana adanya, diinterpretasikan, atau dikomentari secara subjektif. (4) Gambar dapat memberikan isyarat tentang jawaban suatu pertanyaan. (5) Gambar dapat memberi stimulus dan informasi untuk diacu dalam bercakap-cakap, berdiskusi dan bercerita. Dengan demikian jelaslah bahwa pembelaran menulis argumentasi sangat efektif dengan penyampaian materi dengan bermediakan gambar sehingga siswa merespon secara positif.

\section{PENUTUP}

Berdasarkan uraian di atas dapat ditarik simpulan sebagai berikut. Penerapan pembelajaran menulis argumentasi berdasarkan pendekatan konteks dan proses bermediakan gambar dapat meningkatkan aktivitas siswa kelas Vb Lab. Undiksha dalam belajar menulis argumentasi. Pembelajaran yang sebelumnya berpusat pada guru yang lebih banyak aktif, setelah penerapan pembelajaran menulis argumentasi berdasarkan pendekatan konteks dan proses bermediakan gambar, pembelajaran jadiberpusat pada siswa dan aktivitas siswa dalam belajar dapat ditingkatkan.

Penerapan pembelajaran menulis argumentasi berdasarkan pendekatan konteks dan proses bermediakan gambar dapat meningkatkan hasil menulis argumentasi siswa kelas Vb Lab. Undiksha. Hasil rata-rata pembelajaran menulis sebelumnya terbatas pada kategori cukup, setelah diterapkan pembelajaran hasil ratarata pembelajaran menulis siswa mencapai kategori baik.

Siswa merespon secara positif terhadap penerapan pembelajaran menulis argumentasi berdasarkan pendekatan konteks dan proses bermediakan gambar karena siswa merasa menjadi lebih mudah dalam menulis dengan adanya penemuan ide yang akan digunakan sebagai dasar berargumentasi sehingga tinggal merangkai menjadi tulisan argumentative. Hal ini menyebabkan pembelajaran menulis dirasakan lebih menyenangkan dan lebih mudah.

Berdasarkan simpulan di atas, dapat disampaikan saran-saran berikut.

Guru pengajar bahasa Indonesia di SD hendaknya menerapkan hasil penelitian ini dalam pembelajaran menulis dengan kemungkinan disesuaikan karakteristik khusus kelas yang dihadapi. Guru dalam memilih topic sebagai bahan yang hendak ditulis hendaknya dipilih bersama siswa, yaitu sesuatu yang dekat dengan kehidupan siswa dan disukai siswa dengan tetap mempertimbangkan tema yang sedang dikembangkan dalam kurikulum. Penelitipeneliti lain hendaknya dapat melakukan penelitian lanjutan di dalam pembelajaran menulis jenis lain, namun pada tingkat kelas atau jenjang yang berbeda

\section{DAFTAR RUJUKAN}

Balitbang, Depdiknas. (2002). Kurikulum Berbasis kompetensi: Kebijakan Umum Pendidikan Dasar dan Menengah Retorika Suatu Pendekatan Terpadu. Jakarta: Depdiknas.

Jurnal Pendidikan Indonesia | 126 
Bormann, Ernest.G. 1991.. Jakarta: Erlangga.

Cohen, Moshe and Riel, Margaret. (1989). The Effect of Distant Audiences on Student Writing. American Educational Research Journal, 26 (2): 143.

Direktorat Jendral Pendidikan Dasar dan Menengah. (2002). Pendekatan Kontekstual (Contextual Teaching Learning). Jakarta:Depdikdasmen.

Dunkin, Michaell J. dan Bruce,J. Biddle. (1974). The Study of Teaching. New York: Holt Rinehart and Winston, Inc.

Gijselaers, W.H. (1996). Connecting Problem Based Learning With Educational Theory, New Direction for Teaching and Learning, 60, 13 - 21.

Keraf, Gorys. 2004. Argumentasi dan Narasi. Jakarta:PT. Gramedia Pustaka Utama.

Leki,Ilona,Cumming,Alister,and

Silva,Tony.2008. A Synthesis of Research on Second Language Writing in English. New York: Routledge.

Read, John A.S. (1991). "The Validity of Writing Test Tasks". In Anivam, Sarinee. Current Development in Language Testing. Singapore: SEAMEO RELC.

Raimes,Ann.1991. Out of the Words: Emerging Traditions in the Teaching of Writing, TESOL Quarterly, 25 (23):407-429.

Sudarsono, F.X. (1996/1997). Pedoman Pelaksanaan Penelitian Tindakan Kelas: Rencana, Desain dan Implementasi. Jakarta: Dirjen Dikti Depdikbud.

Slamet. (2003). Pelaksanaan Pembelajaran Bahasa dan Sastra Indonesia dengan Kurikulum Berbasis Kompetensi(KBK) pada Uji Coba di SMU Negeri 4 Denpasar. IKIP Negeri Singaraja Program Pasca Sarjana(Tesis).

Sutama,Made. 2010. Pembelajaran Menulis yang Memudahkan."Orasi Pengenalan Jabatan Guru Besar
Tetap dalam Bidang Imu Pendidikan Bahasa Indonesia"(tidak diterbitkan)

Sutama, Made.(1998). Pemaduan Pendekatan Konteks, Proses, dan Pola dalam Meningkatkan mutu Pembelajaran Menulis.(Laporan Penelitian).

Toulmin,S. Rieke R. and Janik A. 1979. An Introduction to Reasoning. New York: Macmillan Publishing Co.

Winch, Gordon et al.2006. Literacy: Reading,Writing, and Children Literature. Oxford: Oxford University Press.

Wright,Raumond E. and Rosenberg,seldom.1993."Knowledge of Text Coherence and Expository Writing: A Developmental Study." Journal of Educational Psychology, 1(85):152-158.

Weir, Cyril J. 1990. Communicative Language Testing. New York: Prentice Hall.

Wendra, I. Wayan. 2009.Pembelajaran Kontekstual Melalui Mengobservasi Objek Otentik untuk Meningkatkan Mutu Pembelajaran Menulis Deskripsi Siswa SMPN4 Singaraja." Jurnal IKA(Ikatan Keluarga Alumni) Undiksha." Vol 7 No.1 Februari hal.31-34. 